\title{
THE FOOD OF \\ SOME BRITISH WILD BIRDS
}

BY

WALTER E. COLLINGE, M.SC, F, LS, S, ES, ETC, 


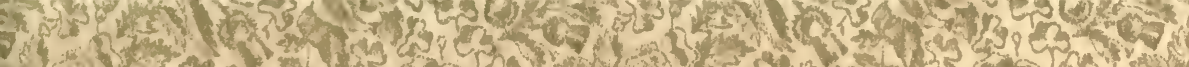
(3)

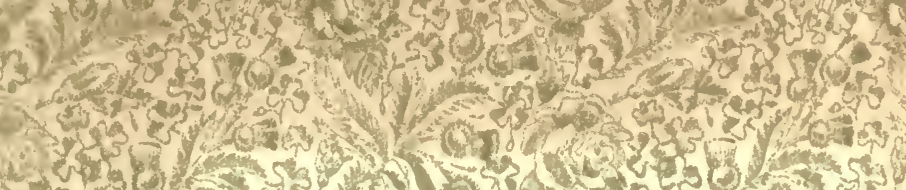

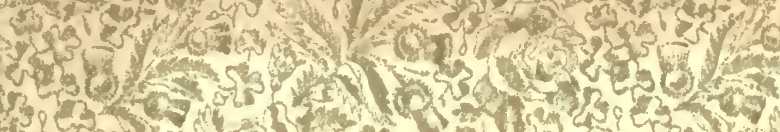

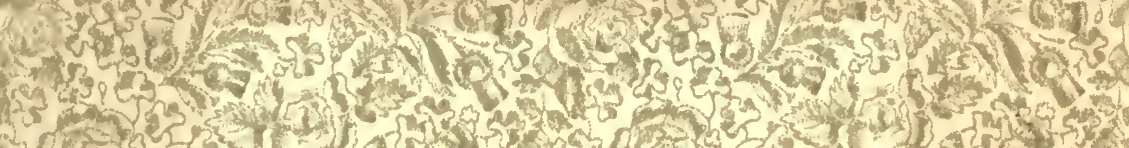
1.

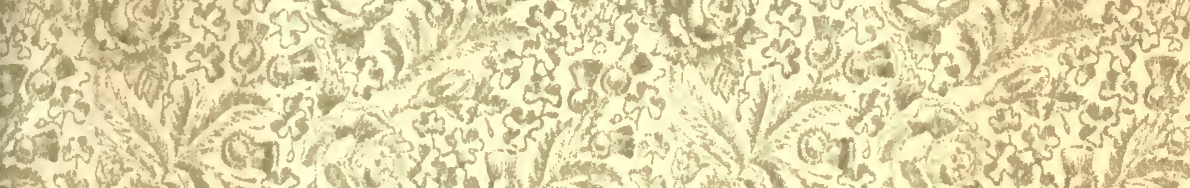

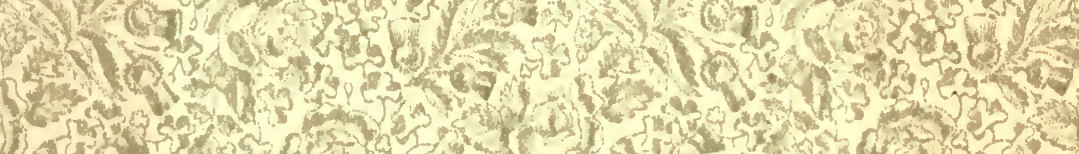

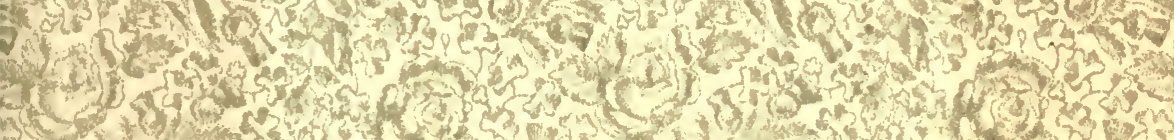

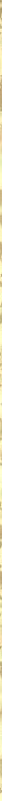

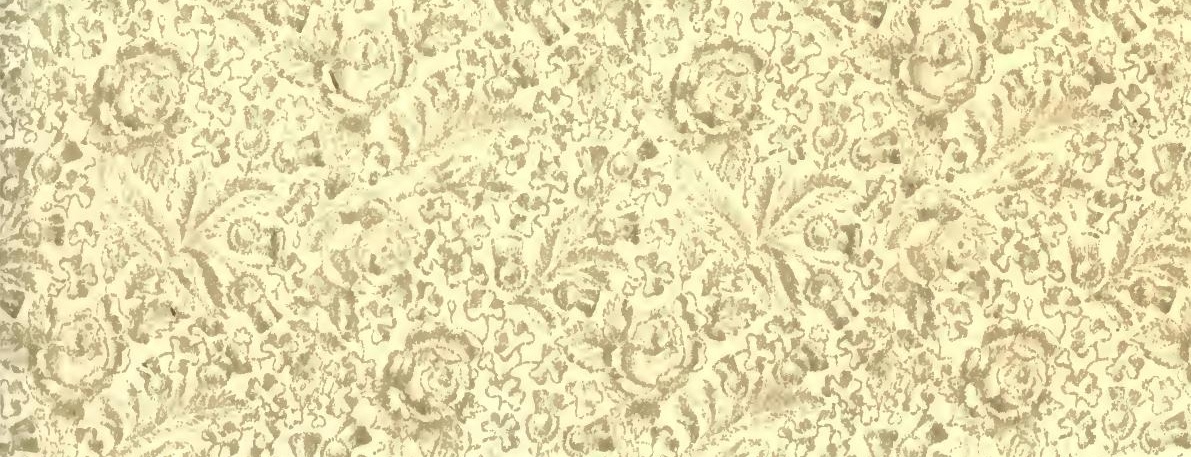




\title{
The Food of \\ Some British Wild Birds:
}

A Study in Economic Ornithology.

BY

\author{
WALTER E. COLLINGE, M.Sc., F.L.S., F.E.S., \\ Foreign Member of the American Association of Economic \\ Entomologists; Honorary Fellow of the Royal Horticultural \\ Society; Joint Honorary Secretary of the Association of \\ Economic Biologists; Editor of the "Tournal of \\ Economic Biology;" and late Special Lecturer \\ on Economic Zoology in the University \\ of Birmingham.
}

"Economic Ornithology has progressed to the point where intensive studies are demanded."

H. C, Bryant.

LONDON :

DULAU \& Co., limited.

1913. 


$$
\mathrm{spo}^{6} \mathrm{C}^{6}
$$




\section{PREFACE.}

* HE nature of the food of many of our wild birds has hitherto been largely guesswork, for with the exception of a very few species no detailed investigations have been carried out, and without these details, obtained in both the field and laboratory, it is impossible to arrive at any sound conclusions respecting their economic status.

The economic importance of the subject to the agriculturist, the horticulturist, the fruit grower, and the forester, and to all who take an interest in our avian fauna, does not here call for any explanation.

The conclusions arrived at in the following pages have only been obtained after a considerable amount of work extending over many years, during which period numerous observations have been made in the field, and of the stomach contents of upwards of three thousand adult birds and three hundred nestlings.

My thanks are due to many helpers, too numerous to be mentioned individually, who have supplied me with various species of birds, at different periods of the year, and from various localities.

Chapters VI. and VII. originally appeared in the Journal of the Board of Agriculture and the Journal of the Land Agents' Society respectively, and my thanks are here tendered for the permission granted to use them in the present work.

WALTER E. COLLiNGE.

8, Newhall Street,

Birmingham. April, igis.

2,4254 



\section{CONTENTS.}

\section{Preface}

PAGE.

I. INTRODUCTION

II. Historical Review

... I

$\ldots, \quad \cdots \quad \cdots \quad \cdots \quad \ldots \quad 5$

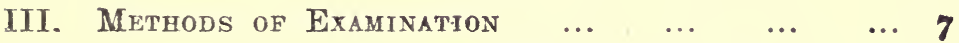

1. Examination of Stomach, etc., Contents $\ldots 7$

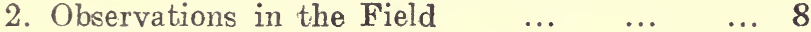

3. Observations on the Food of Nestlings ... $\quad \ldots \quad 8$

4. Examination of Faeces and Pellets $\ldots \quad$... 8

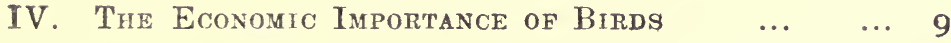

The Food of Nestling Birds ... $\quad \ldots \quad \ldots \quad \ldots$ I 2

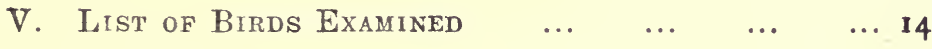
Food of the-

1. Missel Thrush (Turdus viscivorus, Linn.). ... I5

2. Song Thrush (Turdus musicus, Linn.). _.. 16

3. Fieldfare (Turdus pilaris, Linn.). $\quad \ldots \quad \ldots$ I8

4. Blackbird (Turdus merula, Linn.). ... $\quad$... 19

5. Whitethroat (Sylvia cinerea, Bechstein). ...2 I

6. Blackcap (Sylvia atricapilla (Linn.)). ... ...22

7. Great Tit (I'arus major, Linn.). $\quad \ldots \quad \ldots 23$

8. Blue Tit (Parus caeruleus, Linn.). ... ‥ 25

9. Wren ('Troglodytes parvulus, Koch). ... ...27

10. Greenfinch (Ligurinus chloris (Linn.)). $\quad \ldots 28$

11. Goldfinch (Carduelis elegans, Stephens). ... 30

12. House Sparrow (Passer domesticus (Linn.)). ... 31 

13. Chaffinch (Fringilla coelebs, Linn.). $\quad \ldots \quad \ldots 3^{6}$

14. Linnet (Linota cannabina (Linn.)). $\ldots \quad \ldots \quad 3^{8}$

15. Bullfinch (Pyrrhula europaea, Vieillot). ‥ 39

16. Yellow Bunting (Emberiza citrinella, Linn.). ... 42

17. Starling (Sturnus vulgaris, Linn.). $\quad \ldots \quad \ldots 44$

18. Jay (Garrulus glandarius, Linn.). $\quad \ldots \quad \ldots 50$

19. Magpie (Pica rustica (Scopoli)). $\quad \ldots \quad \ldots 5^{\mathbf{I}}$

20. Jackdaw (Corvus monedula, Linn.). ... …53

21. Rook (Corvus frugilè̀us, Linn.). $\quad \ldots \quad \ldots 55$

22. Skylark (Alauda arvensis, Linn.). $\quad \ldots \quad \ldots 59$

23. Barn Owl (Strix flammea, Linn.). ... ... 61

24. Brown Owl (Syrnium aluco (Linn.)). ... . . $66_{3}$

25. Kestrel (Falco tinnunculus, Linn.). ... ‥ $66_{5}$

26. Sparrow Hawk (Accipiter nisus (Linn.)). . .. 66

27. Wood Pigeon (Columba palumbus, Linn.). ... 66

28. Stockdove (Columba oenas, Linn.). ... .. 68

29. Plover (Vanellus vulgaris, Bechstein). ... 69

VI. Birds as Destroyers and Distributers of Weed

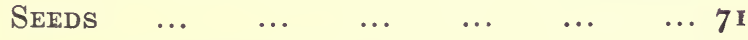

1. Destruction of Weed Seeds $\quad \ldots \quad \ldots \quad \ldots 7 \mathrm{r}$

2. Dispersal of Weed Seeds $\quad \ldots \quad \ldots \quad \ldots 72$

ViI. Birds in Relation to Forestry $\ldots$... $\quad \ldots$ 8 i

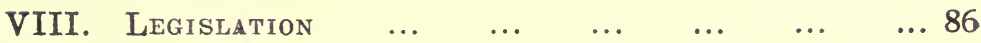

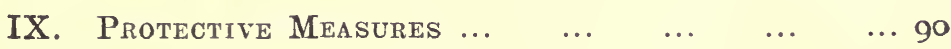

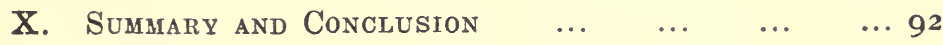

$\begin{array}{llllllll}\text { Bibliography } & \ldots & \ldots & \ldots & \ldots & \ldots & \ldots & 93\end{array}$

$\begin{array}{llllllll}\operatorname{INDEX} & \ldots & \ldots & \ldots & \ldots & \ldots & \ldots & \ldots \text { ro6 }\end{array}$ 
$$
\text { . }
$$ 


\title{
The Food of Some British Wild Birds.
}

\author{
CHAPTER I. \\ INTRODUCTION.
}

" Economic Ornithology, or the study of the inter-relation of birds and agriculture, and an investigation of the foods, habits and plants, is an untrodden and promising field that lies open for investigation by the English agricultural scientist."

Earl Cathcart, The Times, May 16th, 1891.

The nature of the food of many of our wild birds has hitherto been largely guesswork, for, with the exception of a very few species, no detailed investigations have been carried out, and without these details, obtained in both the field and the laboratory, it is impossible to arrive at any sound conclusions respecting their economic status.

In the present investigation upwards of three thousand postmortems have been made of adult birds, and three hundred and twelve of nestlings; and the conclusions arrived at have only been obtained after a considerable amount of work extending over many years, during which period numerous observations have been made in the field.

It is now universally recognised that birds play a most important part in checking the ravages of various animal pests of our crops, particularly so in the case of insects. Prejudice, ignorance and faulty observation have undoubtedly had much to do with our lack of information in the past, whilst many writers have been, and still are, content, when writing upon the subject, to simply reiterate the statements of earlier authors.

Casual observations made in the field, which are frequently put forward in newspaper discussions, are of little value, indeed, they are generally most misleading, as they take no note of what the particular species of bird feeds upon at other seasons of the year, or in other districts, or during the period they are looking after their young.

Many birds which are injurious at one season of the year are distinctly beneficial for the remainder. Again, many birds that are beneficial, may, if allowed to unduly increase, become equally injurious. In other cases the partial failure of their natural food supply, or other causes, may lead to a change in their food habits, in a like manner the alteration or removal of their natural environment may lead to equally disastrous results. 
In districts where the planting of fruit trees is encroaching largely upon what was previously permanent pasture or arable land, a large increase of many species of birds has taken place in recent years. The open fields offered few nesting sites and only a limited food supply. The establishment of orchards means a certain amount of protection by man and the destruction of some, at all events, of their natural enemies. Better facilities are afforded for nesting and new and abundant supplies of food are present. As a result many species have increased in numbers and become exceedingly destructive.

That many of our commoner birds have changed their foodhabits is testified by an annually increasing volume of evidence, thus:-

Mr. O. V. Aplin (68) states: "I am inclined to think that the enormous increase of the starling has caused the rook to alter its food; the starling eats up the animal or vegetable food the rook formerly lived on in the spring, and the rook eats more corn and fruit, and has taken to eating partridge and other birds' eggs to make up for it."

A correspondent, a careful observer and big fruit-grower, writes: "Ten years ago I should have said that the blue tit was deserving of all protection, for its food consisted almost entirely of insects, recently, however, I have had cause to change my opinion of this bird, for it now picks holes in apples, pears and strawberries, and causes a considerable amount of damage. Whilst I would not favour any systematic destruction, it should not be protected, as at present it is too numerous."

Writing in the Field of November 3rd, 1906, a correspondent from Cornwall states: "I have never known it before, but this year the blackbirds have been perfectly ravenous for tomatoes. I have some growing against a wall out-of-doors, and the birds even pecked through fish net to get the fruit; curiously enough no other birds were seen to touch them. I watched a thrush foraging near a partly-eaten tomato and it did not touch it."

I have seen thrushes wilfully bite off the developing stems of carnations and pinks during the spring of 1912. In my own garden scores were bitten almost down to the ground.

A complaint recently reached me from a strawberry grower that he had noticed starlings pecking at the ripe fruit. So far as he could make out there were no insects on the fruit, and examples I examined bore distinct signs of the damage.

Another correspondent records damage to wall-fruit and garden peas by the blackcap. 
Judd (75) mentions the case of the American yellow-bellied woodpecker (Sphyrapicus varius) which has developed a great fondness for the sap of trees, in order to obtain which it pierces a system of more or less symmetrically disposed holes through the bark. Here the sap collects and attracts large numbers of insects which are also devoured. In all probability this is an acquired taste, possibly originally gained when tapping in search of insects. Only profitable trees are punctured, such as apple, birch, maple, and a few others.

In the summer of 1895 nine apple trees about twelve years old, apparently perfectly healthy, were attacked in the autumn by this species, and during the spring and autumn of the succeeding four years they resorted to them regularly. With the aid of powerful glasses two birds were watched for three hours from a distance of twenty feet. During this time one seized an ant and the other snapped at some insect in flight. One drank sap from the holes thirty times and the other forty-one times. Later one of the birds drilled two fresh holes and the other five. In November, 1900, seven of the nine trees were dead, and the remaining two were dying. Bark from one of the trees, when examined, was found to contain eighty-four drill holes, or an average of six to the square inch. Beetles of the flat-headed borer attracted by the exuding sap, had oviposited in the holes, and thus the work of destruction commenced by the birds was completed by these insects.

Pycraft (99) mentions the case of the red-headed woodpecker (Melanerpes erythrocephala) "which, like its congeners, possesses a protrusible tongue ostensibly for the capture of insect prey, yet lives at any rate very largely, on eggs of other birds, even entering hen-roosts in its quest for these delicacies! Furthermore, and perhaps as a natural sequence, it devours young birds, which are killed by a blow on the head with the dagger-like bill, and through the hole thus made the tongue is thrust for the purpose of sucking out the brains! It is recorded that, in Ohio, a colony of swallows, represented by some dozens of nests, was so completely raided that not a single young one was reared! Occasionally, frogs were eaten, perhaps by way of varying the diet. We must assume that this strange departure has been but recently made, for, as yet, the elaborate mechanism characteristic of the woodpecker shows no signs of degeneration."

As I have elsewhere (30) pointed out, it is with reference to, comparatively speaking, a few species only that so much diversity of opinion exists. Of the majority of species it is universally agreed that they are beneficial, I have, therefore, not deemed it necessary for the purpose of this investigation, to destroy any of the truly insectivorous species, in order to ascertain more precisely the exact nature of their food. 
"We have about two hundred and eighty species of British birds, a fair percentage of which are so rare or so small in numbers, that they do not effect the subject under consideration. In the same manner, all those species aquatic or littoral in their habits may be left out of consideration. Thus we reduce the list down to about eighty-five species, of which fifty may be said to feed exclusively upon insect life, such, for instance, as the swift, swallow, martin, flycatchers, wagtails, etc.

This leaves us about thirty-five species, of which the commonest are :-

Missel Thrush (Turdus viscivorus, Linn.).

Song Thrush (Turdus musicus, Linn.).

Fieldfare (Turdus pilaris, Linn.).

Blackbird (Turdus merula, Linn.).

Whitethroat (Sylvia cinerea, Bechstein).

Blackcap (Sylvia atricapilla (Linn)).

Great Tit (Parus major, Linn.).

Blue Tit ('Parus caeruleus, Linn.).

Wren (Troglodytes parvulus, Koch).

Greenfinch (Ligurinus chloris (Linn)).

Goldfinch (Carduelis elegans, Stephens).

House Sparrow (P'asser domesticus (Linn.)).

Chaffinch (Fringilla coelebs, Linn.).

Linnet (Linota cannabina (Linn.)).

Bullfinch (Pyrrhula europaea, Vieillot).

Yellow Bunting (Emberiza citrinella, Linn.).

Starling (Sturnus vulgaris, Linn.).

Jay (Garrulus glandarius, Linn.).

Magpie (I'ica rustica (Scopoli)).

Jackdaw (Corvus monedula, Linn.).

Rook (Corvus frugilegus, Linn.).

Skylark (Alauda arvensis, Linn.).

Barn Owl (Strix flammea, Linn.).

Brown Owl (Syrnium alues (Linn.)).

Kestrel (Faleo timnunculus, Linn.).

Sparrow Hawk (Accipiter nisus (Linn.)).

Wood Pigeon (Columba palumbus, Linn.).

Stockdove (Columba oenas, Linn.).

Plover (Vanellus vulgaris, Bechstein).

Respecting these twenty-nine species, I have for some years been collecting information as to the nature of their food, and generally their economic status, full details of which are now set forth. 


\section{CHAPTER II. \\ HISTORICAL REVIEW. \\ "Der wird stets das Beste missen, Wer nicht borgt, was andre wissen."}

Rückert.

Until quite recently comparatively little work had been carried out in this country upon economic ornithology. In most of the works on British birds the information given is scanty and in general terms, indeed, it is significant that scarcely a writer on economic ornithology has thought it worth while repeating these statements.

The Bibliography (p. 93 ) contains, I think, all the more important papers published in this country, and references to many others. Gurney (57) in 1885 published a paper on the house sparrow, showing the exceedingly destructive nature of this bird. Gilmour (54) in 1896 dealt with the wood pigeon, the rook, and the starling, and was the first investigator in this country to carry his observations over a whole year and on a reasonably representative number of specimens, thus the stomach contents of 265 pigeons, 355 rooks, and 190 starlings were examined.

Archibald's series of papers ( $3 \& 4$ ) bring together practically all that was known up to 1894. Slater's contribution (104) is more of a bird-lover's appeal on behalf of our "feathered friends." In 1897 (95) Ormerod and Tegetmeier isued a pamphlet dealing with the house sparrow as a pest. Hooper (68) in 1906 published a valuable contribution to the subject, the outcome of careful observation, indeed, it may be said to form the first comprehensive survey of the subject published in this country. This was followed by a further contribution in the following year (69). Theobald (109) gave a useful review of the subject in the same year. Thorpe and Hope (111) have investigated the food of the black-headed gull, as also Laidlaw (80).

In 1908 Archibald (5) supplemented and completed his former work. Newstead's paper (92) of the same year was the frst one since Gilmour's to set forth the results of examinations of stomach contents. So far as the questionable species are concerned it does not afford much assistance, however, as the number of individuals examined was, in most cases, too small, the numbers being :- 
blackbird, 12 ; song thrush, 9 ; missel thrush, 3 ; whitethroat, 5 ; blackcap, 3 ; blue tit, 34 ; greenfinch, 11 ; chaffinch, 27 ; linnet, 4 ; bullfinch, 23 ; yellow bunting, 4 ; jay, 22; magpie, 8 ; jackdaw, 11 ; rook, 14 ; skylark, 6 ; starling, 16 ; the paper, however, contain: much valuable information. Herman and Owen's work (65) issued in 1909 , can scarcely be regarded as a serious contribution to the subject.

In 1910 my report on the feeding habits of the rook was published (31). The inquiry extended over forty-one counties of England and Wales during the whole of 1909. The conclusions arrived at were based upon 830 post-mortems. Further contributions dealing with the food of the starling (32), and bullinch (33), followed. Dunlop (39) in the same year published an interesting paper on the feeding habits of owls.

Florence (47) in 1912 published the results of an examination of 616 stomach contents; as in the case of Newstead's paper, the number of individuals was generally too small. For comparison, they were:-blackbird, 29 ; song thrush, 6 ; missel thrush, 3 ; blue tit, 8; greenfinch, 11 ; chaffinch, 34 ; bullfinch, 2 ; yellow bunting, 21 ; magpie, 1 ; jackdaw, 1 ; rook, 162 ; skylark, 2 ; starling, 28 ; wood pigeon, 11 ; rock dove, 2.

Hammond (60) gave a very valuable and detailed account of the food of the starling and skylark, and in the same year I published a paper on the food of nestling birds (34), also a general review of the economic status of wild birds (35).

The relation of wild birds to forestry and as destroyers and distributers of weed seeds I have dealt with in two recent papers (36 and 36a) which are reproduced in the present work with some slight alteration.

In the United States of America very valuable work has been done by Beal (10-20), Judd (70-77), McAtee (82-87), Palmer (96 and 97), A. K. Fisher (42-45), Bryant (23-25), Barrows (8\& 9), and others. Nash (91) and Eifrig (41) have treated of the subject with reference to the Birds of Canada., French (49 and 50), and Cleland (27) respecting those of Australia, and Mason and Maxwell-Lefroy (89) on the Birds of India. 


\section{CHAPTER III.}

\section{METHODS OF EXAMINATION.}

"To obtain adequate knowledge of the food of birds in relation to agriculture, a definite scheme of procedure must be followed. Simply observing the birds while they are feeding gives only fragmentary information . . The results thus obtained must be supplemented by other and corroboratory evidence."

Sylvester D. Judd.

In order to arrive at a proper understanding of the food of any particular species, it is necessary to examine the food contento found in the intestinal tract during the different seasons of the year and from various districts. Further, careful observations must be made in the field, and of the nature of the food brought to the nest by the parents during the breeding season; and also of the faecal contents extruded from the nest.

If the collection of this information extends over the whole of the twelve months of the year, for successive years, and in different localities, and provided sufficient care is used in the identification of the food materials and their percentages, I believe a very correct idea may be formed of a bird's food and whether or not the particular species is injurious or beneficial.

Various methods of examination have been recommended, those carried out by myself are as follows:-

\section{Examination of Stomach, etc., Contents.}

In nearly all cases the stomach contents have been examined when fresh, viz., four to twenty hours after the birds were shot. Stomach contents preserved in alcohol are preferable to those preserved in formalin, but neither are satisfactory.

On opening the body-cavity the whole of the intestinal tract, from the oesophagus to the rectum inclusive, was removed and laid in a flat-bottomed, shallow, white dish, here the whole length was slit open with a pair of scissors and the entire contents removed, partly with the aid of a scalpel, forceps, a brush and a little water. The contents were then spread out over the dish and examined with a large magnifying glass. With forceps, all the seeds were transferred to a smaller white, shallow saucer, insect remains to another, vegetable matter to a third and so on. The remaining material was washed several times and the residue subjected to 
careful examination under the microscope. This latter procedure is most important, as in this way much information is gained, as this residue includes amongst other things-mouth-parts of insects and their larvae, antennae, scales, wings, legs, etc., insect eggs, small and broken seeds, starch grains, spicules of earthworms, etc., etc.

The whole of the materials were then scheduled together with such other particulars as were thought to be of importance, e.g., date, locality, sex.

\section{Observations in the Field.}

In endeavouring to form a correct estimate of a bird's food, and whether or not it is beneficial or injurious, too much importance cannot be placed upon careful and accurate field observations.

A pair of good field glasses are necessary. In the orchard I have found a sloping plank of wood to lie on, and an old mackintosh coat to cover one's body with, very useful. In other situations an umbrella is not to be despised. For more open spaces an excellent arrangement can be made by a light wooden framework consisting of two halves $60 \mathrm{in}$. by $30 \mathrm{in}$., hinged with leather. Over this, dirtygreen calico is tacked, through which various observation holes can be made. The observer seats kimself with his back to a hedge, tree, shed, etc., and opens the framework in front of him thus : $A$. Two such frameworks, with an open umbrella as a roof, form a comfortable and valuable vantage-ground for almost any field observations.

\section{Observations on the Food of Nestlings.}

I have found the arrangement described above most useful for observing the nature of the food brought by the parents to the nest. Other observations have been made from behind a curtained window.

\section{Examination of Faeces and Pellets.}

A considerable amount of very valuable information may be obtained from careful and systematic examination of the droppings of birds, but, as will be gathered from the observations later recorded, large quantities, and at different seasons of the year, must necessarily be examined if this source of information is to prove of any value. 


\section{CHAPTER IV.}

\section{THE ECONOMIC IMPORTANCE OF BIRDS.}

\section{"The feeling seems to be practically universal that birds as a} class, notwithstanding their sins, still do more good than harm."

$$
\text { F. E. L. BEAL (17, p. 13). }
$$

From the earliest times man has recognised that there existed a relationship between the birds of the air and his crops. Ancient records show that certain species were regarded as injurious and certain species beneficial, and means were devised to destroy the one and protect the other. But it is only in, comparatively, recent years that the economic importance of birds has been realised and their habits scientifically studied.

In the United Kingdom reliable statistics as to the nature and quantity of the food required by the different species, have been few, and in most instances the number of individuals examined of a particular species has been too small, and the examination often having taken place during a particular month or season, the conclusions drawn have naturally been faulty or inconclusive.

The subject is one hedged round with difficulties, as Professor Theobald (109) remarks: "The subject of the economic status of wild birds is one that has to be approached in so many different ways that it is almost impossible to formulate any satisfactory plan of treating this important matter." "It must, however, be borne in mind that, in nearly all cases, the misdeeds of birds are much more manifest than the benefits they confer upon us." "Birds affect both sides of the farmer's balance sheet to an almost incalculable extent. Unfortunately, the means by which they reduce the profits of cultivation are only too apparent, whilst the good services rendered by them, both on the farm and in the garden, are in many cases only discernable by those who have studied their ways very thoroughly, and who have besides a fair knowledge of insect pests, and their boundless power for evil." (3).

It is now generally agreed that, with perhaps one or two exceptions, the wholesale destructon of birds for the purpose of protecting crops and orchards is, economically, an unsound policy. Conditions which in one district may tend to make a species destructive or even injurious, do not obtain in another, where the same species is equally beneficial. Again, many birds are distinctly injurious at certain seasons of the year only and equally beneficial at others. In these cases it is very important that we should 
endeavour to rightly estimate the status of a particular species before it is either reduced in numbers or encouraged to increase.

In almost every case where general complaints are made of the damage done by birds, careful enquiry has shown that only a very few species were to blame, the cause in each case being: "too" many individuals of the same species in one locality eating the same things." It is frequently happening that a bird which by the nature of its food is beneficial, on becoming abundant becomes to be regarded as an injurious species, our own starling (Sturnus vulgaris) is an instance, but a more striking one is the house finch or linnet (Carpodacus mexicanus frontalis) of California.

Although orchardists have been loud in their condemnation of this bird, careful inquiry shows that it is essentially a seed-eater. An investigation of 1,206 stomachs, including 46 of nestlings, taken during the whole of the months of the year, from localities welldistributed over the State of California, showed that the greater portion of its food consisted of the seeds of weeds, the total consumption for the year working out at 86.2 per cent. Fruit was found in only 297 stomachs, or 24 per cent. of the whole number, and of these only 38 , or 3 per cent. of all, were entirely filled with it. In short, 909 stomachs contained no fruit, and there were only 63 stomachs that did not contain weed seeds.

The table of percentage of food for each month in the year is given below :-

\begin{tabular}{|c|c|c|c|c|c|c|}
\hline \multirow{2}{*}{ Month. } & \multirow{2}{*}{$\begin{array}{c}\text { Number } \\
\text { of } \\
\text { stomachs } \\
\text { examined }\end{array}$} & \multirow{2}{*}{$\begin{array}{l}\text { Animal } \\
\text { food } \\
\text { eaten. }\end{array}$} & \multirow{2}{*}{$\begin{array}{l}\text { Weed } \\
\text { Seed. }\end{array}$} & \multicolumn{3}{|c|}{ Vegetable food eaten. } \\
\hline & & & & Fruit. & $\begin{array}{l}\text { Miscel- } \\
\text { laneous. }\end{array}$ & $\begin{array}{l}\text { Total vege- } \\
\text { table food. }\end{array}$ \\
\hline January & 88 & $\begin{array}{c}\text { Per cent. } \\
0.0\end{array}$ & $\begin{array}{c}\text { Per oent. } \\
99.8\end{array}$ & $\begin{array}{c}\text { Per cent. } \\
0.2\end{array}$ & $\begin{array}{c}\text { Per cent. } \\
0.0\end{array}$ & $\begin{array}{l}\text { Per cent. } \\
100.0\end{array}$ \\
\hline February & 35 & 2.9 & 97.1 & 0.0 & 0.0 & 97.1 \\
\hline March & 186 & 1.0 & 89.5 & 5.8 & 3.6 & 99.0 \\
\hline April & 80 & 5.8 & 92.5 & 1.7 & 0.0 & 94.2 \\
\hline May & 74 & 6.3 & 88.9 & 4.8 & 0.0 & 93.7 \\
\hline June & 167 & 3.9 & 81.6 & 13.4 & 1.2 & 96.1 \\
\hline July & 148 & 2.2 & 76.5 & 19.7 & 1.5 & 97.8 \\
\hline August & 118 & 7.1 & 64.0 & 27.4 & 1.5 & 92.9 \\
\hline September & 123 & 0.1 & 71.6 & 26.7 & 1.6 & 99.9 \\
\hline October & 108 & 0.0 & 83.5 & 15.6 & 0.9 & 100.0 \\
\hline November & 25 & 0.0 & 91.7 & 8.3 & 0.0 & 100.0 \\
\hline December & 54 & 0.0 & 97.8 & 1.8 & 0.4 & 100.0 \\
\hline Total & & & & & & \\
\hline Average & 1,206 & 2.4 & 86.2 & 10.4 & 0.9 & 97.5 \\
\hline
\end{tabular}


Taking a rapid survey of our British species of wild birds of the family, Turdidac, the missel thrush, song thrush, fieldfare and blackbird are the only ones of doubtful character, the rest are all beneficial or too few in numbers, at present, to be regarded as injurious. Of the Paridae, or tits, a diversity of opinion exists. The dipper, nuthatch, wren, the wagtails, pipits, flycatchers, swallows, martins and tree creeper are all beneficial, as also the warblers, excepting the whitethroat (Sylvia cinerea, Bechst.), the blackcap (S. atricapilla, Linn.) and the garden warbler (S. hortensis, Bechst.).

Of the large families of finches and buntings, the goldfinch, hawfinch, greenfinch, chaffinch and linnet are frequently recorded as doing harm, whilst the house sparrow and bullfinch are distinctly injurious. Of the buntings, the yellow bunting and corn bunting where numerous, often do a considerable amount of harm.

The food-habits of the Corvidae have not as yet been particularly well investigated. I have shown in the case of the rook that this species has undoubtedly become far too plentiful, and, in consequence, injurious. The jackdaw, magpie, and jay, to a certain extent, fall into a similar category. Their numbers in many parts of the country require reducing.

The wood-peckers (Picadae), although occasionally destructive to trees, telegraph poles, etc., are, on the whole, beneficial. Fisher (45a) states: "The results of investigation into the utility of woodpeckers tend to show that these birds, by their activity in the destruction of insects, play a most useful part in nature, and should, therefore, be protected by foresters."

The wryneck (Iynx torquilla, Linn.), kingfisher (Alcedo ispida, Linn.), and their allies are all beneficial, as also the cuckoo (Cuculus eanorus, Linn.), the latter feeding upon various hairy caterpillars.

The Strigidae or owls are, as a class, most beneficial.

Of the "Birds of Prey," whilst they undoubtedly do a certain amount of harm to game and poultry, the good they do in keeping down rats, mice and voles far outweighs this.

The Columbidae (mood-pigeon, stockdove, etc.), are all injurious, and should be destroyed.

Game-birds, although causing a certain amount of damage to young forest plantations, seed-corn, etc., do a considerable amount of good, and may be regarded as beneficial, and the same may be said of the gulls (Laridae). 
It is now generally conceded that the majority of birds are beneficial, and, as elsewhere stated, it is only in connection with a small number that any doubt exists, and it is in connection with these few that we are gradually accumulating reliable data that must prove of considerable value.

\section{The Food of Nestling Birds.}

It is a well-known fact that nestlings consume during the first few days of their life considerably more than their own weight of food per day, making a daily gain in weight of from twenty to even fifty per cent. During this period feeding commences before sunrise and continues until after sunset. The number of meals taken during this period is very large. Weed* records that in the case of the Chipping Sparrow (Spizella socialis) the total number of visits paid by the parent birds, bringing food, in a day amounted to nearly two hundred. Judd (73) writing of the House Wren (Troglodytes aëdon) states "that nestlings are fed very frequently, and consume an enormous quantity of food, is well known by a halfday's observation," made by him on June 17th, 1899. He watched the feeding of a brood of three. "The family was found housed in a cavity in a locust tree, and was transferred to a baking-powder can, which was nailed to the trunk of the tree four feet above the ground, a convenient height for observation. The young were about three-fourths grown." The mother wren made 110 visits in four hours and thirty-seven minutes. On the following day similar observations were made, and in three hours and five minutes the young were fed 67 times. Newstead (92) has also given details for the starling as follows:-

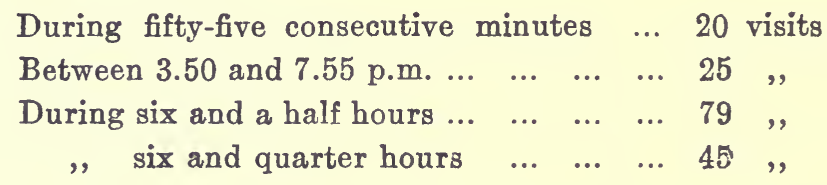

Thus, "during a total period of seventeen hours, representing approximately the hours of one day during which food was collected for the young, 169 journeys were made to the nest." This is in all probability much under the average.

Our knowledge of the nature and amount of food consumed by nestling birds is as yet very meagre. The subject is an important one, for many birds that in the adult condition feed l'pon both animal and vegetable matter, feed their young almost entirely

* Bull. No. 55, New Hampshire Agric. Exp. Stat., 1898. 
upon insects, worms, and slugs. Indeed, from the nature of the structure of the stomach of a newly-hatched bird it may be generally concluded that most birds (excluding aquatic and raptorial species) feed their young on soft food, which largely consists of insects, slugs, spiders, and worms.

As has been pointed out by Judd (73, p. 435) practically all birds, excepting doves and pigeons, feed their young upon an animal diet, whatever may be the character of the food of the adult. Only continued observation will ultimately place us in possession of the nature and amount of food eaten by nestlings, and such information must ultimately prove of great value to all concerned with the raising of crops, whether fruit; general farm, or horticultural.

In conclusion, "it should be remembered that the nestling season is also that when the destruction of injurious insects is most needed, that is, at the period of greatest agricultural activity and before the parasitic insects can be depended on to reduce the pests." A knowledge, therefore, of the nature of the food, the amount consumed, and the relation this bears, from an economic standpoint, to the harm done by some species when adult, is no longer a question of interesting curiosity on the part of the birdlover, but one that has a definite bearing on the success or failure of the produce of the land. 


\section{CHAPTER V. \\ LIST OF BIRDS EXAMINED.}

"The economic value of birds must bo considered from all points of view in a very broad spirit."

F. V. Theobald (109, p. 20).

No useful purpose would be served in detailing the stomach contents of the different specimens of each species examined, for some I have given these particulars elsewhere and some further ones are included here, but it is important that the reader should have some data provided in order to indicate upon what the present study has been founded. I therefore give below:-

1. A list of the various species examined.

2. The number of each species.

3. Where nestlings have been examined and numbers.

4. Where faeces or pellets have been examined.

\begin{tabular}{|c|c|c|c|c|c|c|}
\hline \multicolumn{4}{|c|}{ Species. } & \multirow{2}{*}{$\begin{array}{c}\begin{array}{c}\text { No. of } \\
\text { specimene. }\end{array} \\
12\end{array}$} & \multirow{2}{*}{$\begin{array}{c}\begin{array}{c}\text { No. of } \\
\text { nestlings. }\end{array} \\
0\end{array}$} & \multirow{2}{*}{$\begin{array}{l}\text { Faeces or Pel- } \\
\text { lets examined } \\
\text { where marked } \times \\
\times\end{array}$} \\
\hline Missel Thrush & $\cdots$ & $\cdots$ & $\cdots$ & & & \\
\hline Song Thrush & $\cdots$ & $\cdots$ & .. & 64 & 20 & $\times$ \\
\hline Fieldfare & ... & $\ldots$ & ... & 30 & 0 & 0 \\
\hline Blackbird & $\cdots$ & $\ldots$ & $\ldots$ & 89 & 23 & $x$ \\
\hline Whitethroat & $\ldots$ & $\ldots$ & $\ldots$ & 17 & 0 & 0 \\
\hline Blackcap & $\cdots$ & $\cdots$ & $\cdots$ & 33 & 4 & 0 \\
\hline Great Tit & ... & $\ldots$ & .. & 20 & 0 & 0 \\
\hline Blue Tit & ... & $\ldots$ & $\ldots$ & 38 & 10 & $x$ \\
\hline Wren ... & $\ldots$ & $\ldots$ & $\ldots$ & 4 & 8 & 0 \\
\hline Greenfinch & $\ldots$ & $\ldots$ & $\cdots$ & 42 & 13 & $x$ \\
\hline Goldfinch & $\ldots$ & $\ldots$ & $\ldots$ & 54 & 0 & 0 \\
\hline House Sparrov & $w \ldots$ & $\ldots$ & $\ldots$ & 404 & 42 & $x$ \\
\hline Chaffinch & $\ldots$ & $\ldots$ & $\ldots$ & 68 & 12 & 0 \\
\hline Linnet ... & $\cdots$ & $\ldots$ & $\ldots$ & 39 & 10 & 0 \\
\hline Bullfinch & $\cdots$ & $\cdots$ & $\cdots$ & 484 & 13 & $x$ \\
\hline Yellow Buntin & & $\cdots$ & $\ldots$ & 30 & 8 & $x$ \\
\hline Starling & $\ldots$ & ... & $\cdots$ & 328 & 94 & $x$ \\
\hline Jay $\ldots$ & $\cdots$ & $\cdots$ & ... & 18 & 0 & 0 \\
\hline Magpie & $\cdots$ & ... & $\cdots$ & 24 & 0 & 0 \\
\hline Jackdaw & ... & $\ldots$ & $\ldots$ & 30 & 0 & 0 \\
\hline
\end{tabular}




\begin{tabular}{|c|c|c|c|c|c|c|}
\hline \multicolumn{4}{|c|}{ Species } & \multirow{3}{*}{$\begin{array}{c}\begin{array}{c}\text { No. of } \\
\text { Specimens }\end{array} \\
721 \\
40\end{array}$} & \multirow{2}{*}{$\begin{array}{c}\begin{array}{c}\text { No. of } \\
\text { Nestlings }\end{array} \\
16\end{array}$} & \multirow{2}{*}{$\begin{array}{c}\begin{array}{c}\text { Faeces or Pel- } \\
\text { lets examined } \\
\text { where markdx }\end{array} \\
0\end{array}$} \\
\hline Rook & $\ldots$ & $\ldots$ & ... & & & \\
\hline Skylark & $\ldots$ & $\ldots$ & $\ldots$ & & 9 & 0 \\
\hline Barn Owl & $\ldots$ & $\ldots$ & $\ldots$ & 7 & 0 & $x$ \\
\hline Brown Owl & $\ldots$ & $\ldots$ & $\ldots$ & 6 & 0 & $x$ \\
\hline Kestrel ... & $\ldots$ & ... & $\ldots$ & 16 & 0 & 0 \\
\hline Sparrow Haw & & $\ldots$ & $\ldots$ & 6 & 0 & 0 \\
\hline Wood Pigeon & $\ldots$ & $\ldots$ & $\ldots$ & 388 & 0 & $x$ \\
\hline Stockdove & $\ldots$ & $\ldots$ & $\ldots$ & 34 & 0 & 0 \\
\hline Plover ... & $\ldots$ & $\ldots$ & ... & 12 & 0 & 0 \\
\hline Totals & $\ldots$ & $\ldots$ & $\ldots$ & 3048 & 312 & - \\
\hline
\end{tabular}

In the following summaries of the food, where a query follows a number in the columns headed "Number occurred," the figures are only approximately correct, in all cases where any doubt existed the lower figure was taken.

Further, much of the material scheduled under "Neutral" is really "Injurious," such as the seeds of weeds.

\section{MISSEL THRUSH.}

\section{Turdus viscivorus, Linn.}

This bird, like many members of its family, has largely increased in numbers during the past quarter of a century.

Archibald (3) writing in 1893, says: "This fine thrush has rendered itself unpopular in some districts by exhibiting too great a partiality for fruit. Its food, however, consists largely of wild cherries, and the berries of the yew, hawthorn, holly, service-tree, mountain-ash, juniper, and ivy; whilst its fondness for the berries of the mistletoe has gained for it the name by which it is generally known. Like other members of its family, it renders good service by devouring slugs and the destructive larvae of beetles and moths. Earthworms also form a considerable portion of its sustenance."

Hooper (68) states: "In Kent it is considered one of the worst birds with fruit, specially troublesome with cherries and soft fruit; it persistently eats pears, apples, plums, damsons, and many kinds of berries; it is fond of black currants, which most birds avoid."

Smith (105) writes: "Thrushes, I think, are almost as bad as blackbirds. They do not eat figs, and are not so troublesome with the apples, but all other fruit they are as partial to as the blackbird. The thrush is partially migratory, going south as the weather gets winterly. If the North and Midlands have much snow they 
come to our county, and seeing plenty of fruit trees they stay on and add to our already over-crowded bird population."

A Worcestershire correspondent writes: "After many years careful observation I have come to the conclusion that the Missel Thrush is far too plentiful, and in fruit-growing districts certainly does more harm than good."

\section{Post-mortem Records.}

Only twelve birds have been examined, viz., two in April, three in May, five in June, and two in July. In all but the April specimens the contents consisted of fruit-pulp and seeds. Those examined in April contained remains of beetle larvae and slugs.

\section{Field Observations.}

On numerous occasions I have seen this species feeding upon cherries, plums, and black currants; also the berries of mountain. ash, juniper, hawthorn, holly and ivy. Beetle larvae, such slugs as Arion hortensis, Fér. and Agriolimax agrestis, Linn., and earthworms are also eaten.

\section{Conclusion.}

In fruit-growing districts this bird should be kept down, for four months in the year it does more harm than is counter-balanced during the remainder of the year. It is more and more becoming a fruit-eater and for many years past has shown an annual increase in numbers.

\section{SONG THRUSH.}

Turdus musicus, Linn.

Unfortunately this bird is often confounded with the Missel Thrush, and is frequently blamed for the latter birds' acts. Whilst to a certain extent similar in its food habits, its liking for fruit is by no means so pronounced.

Hooper (68) refers to it as destroying "large quantities of strawberries, cherries, red currants, and raspberries, but does not, like the blackbird, peck apples and plums on the trees; worst in dry weather when its natural food, consisting of worms, snails, grubs, and slugs, is hard to get. One grower mentions it eating raspberry weevils."

\section{Post-Mortem Records.}

Sixty-four specimens were examined extending over the whole of the year. The materials found were summarised as follows:- 


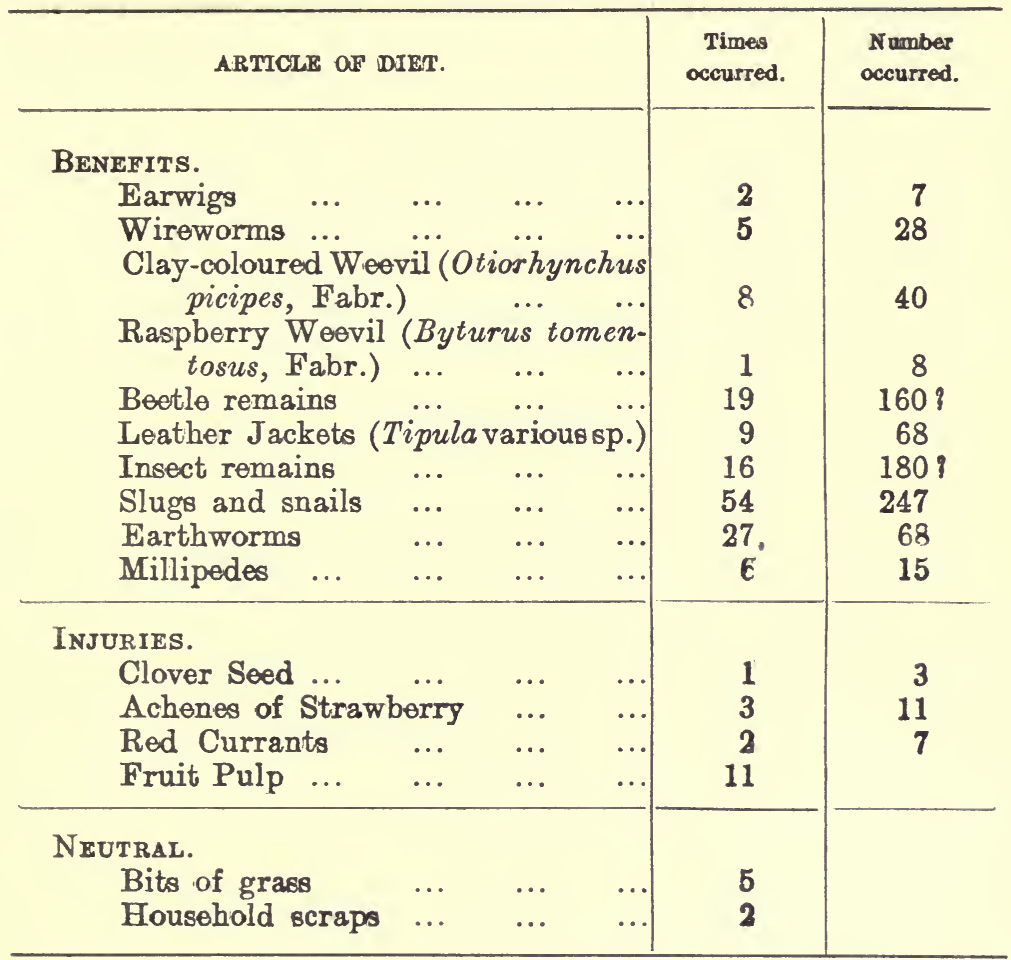

\section{Field observations.}

I have paid considerable attention to this bird in the field, and on all occasions have had nothing to record against it. In Oxfordshire I once watched two birds break up on a large stone by the side of a hedge, forty-seven specimens of the two snails Helix hortensis and $H$. nemoralis, Linn. The spot was evidently a favourite feeding ground, for there were large quantities of broken snail shells, amongst which I identified upwards of eighty shells of the garden snail ( $H$. aspersa, Müll.).

It has been frequently mentioned to me that this bird damages strawberries, but although I have watched it very carefully I have never seen it attack the fruit. In most cases it has been after slugs and beetles.

\section{Food of Nestlings.}

The food of the young is all in favour of this species. Of twenty specimens examined, the following food-contents were made out:-1 larva of Noctuid moth; 3 wireworms; remains of earth- 
worms and slugs in all cases; 4 spiders; vegetable matter and soil in all cases.

\section{Conclusion.}

The song thrush, whilst it occasionally does damage to cherries and red currants, and still less to strawberries and raspberries, cannot be regarded as anything but beneficial to the fruit-grower and horticulturist. The percentage of vegetable food it takes is very small, whilst the bulk of the animal food consists of injurious insects, slugs and snails, millipedes and earthworms.

\section{FIELDFARE.}

\section{Turdus pilaris, Linn.}

Some years ago this handsome autumn visitor was reported to me as injuring fruit. The two examples forwarded were examined, but no fruit was found in their stomachs. A little later five more specimens were sent, with practically similar results.

An investigation made in the orchard conclusively proved that this species was not the culprit, and the stomach contents of twenty-three birds showed the food to consist of the following material :-

\begin{tabular}{|c|c|c|}
\hline ARTICLE OF DIET. & $\begin{array}{c}\text { Times } \\
\text { occurred. }\end{array}$ & $\begin{array}{l}\text { Number } \\
\text { occurred. }\end{array}$ \\
\hline 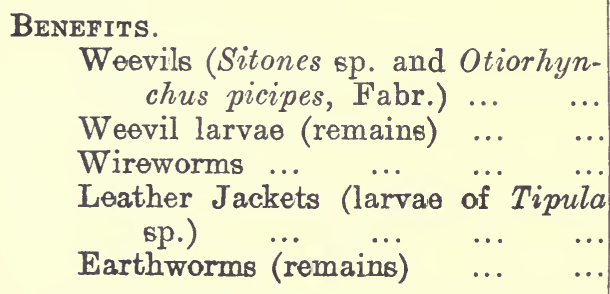 & $\begin{array}{r}19 \\
18 \\
13 \\
\\
13 \\
9\end{array}$ & $\begin{array}{l}149 \\
139 \\
111 \\
\\
57 \\
32 ?\end{array}$ \\
\hline INJURIES. & & \\
\hline 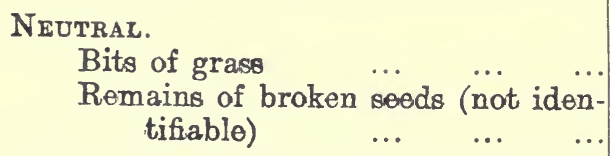 & 6 & \\
\hline
\end{tabular}




\section{BLACKBIRD.}

\section{Turdus merula, Linn.}

The enormous increase of recent years in the number of blackbirds has seriously affected fruit-growers and others. Smith (105) writing in 1906, stated that in Kent: "Blackbirds have increased enormously of late years. Before gun licenses came into force they were kept down very much by people going round the roads and shooting them in winter. Large numbers were killed in this way, but I think no one wishes to see every village lad running about with a gun, to the danger of himself and the public. Of late years, we have had very mild winters, and that has allowed them to increase very much; also a much larger acreage of land is strictly preserved for game now, and that allows the birds to breed in safety. The blackbirds begin to eat fruit as soon as it colours, and spare no variety, beginning with early strawberries and going on to gooseberries, currants, raspberries, cherries, plums, damsons, apples, pears, and figs. The damage they do is very considerable, as they spoil as much as they eat, or even more. I have for the last seven or eight years trapped over 1,000 blackbirds and thrushes yearly. This year, from the quantity left to breed, I shall have to destroy at least 2,000 to keep them at all within boundsthat is on about 200 acres of fruit."

\section{Post-mortem Records.}

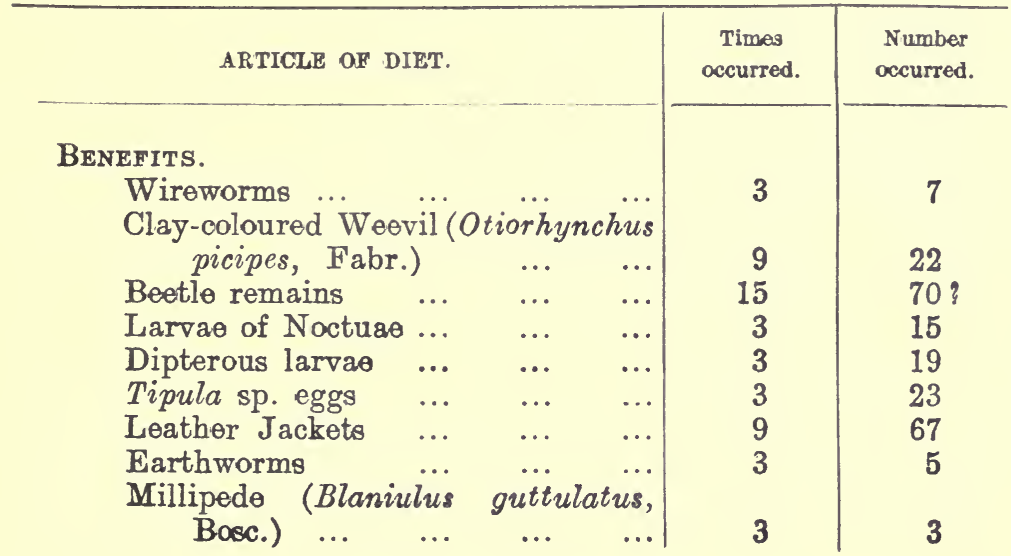




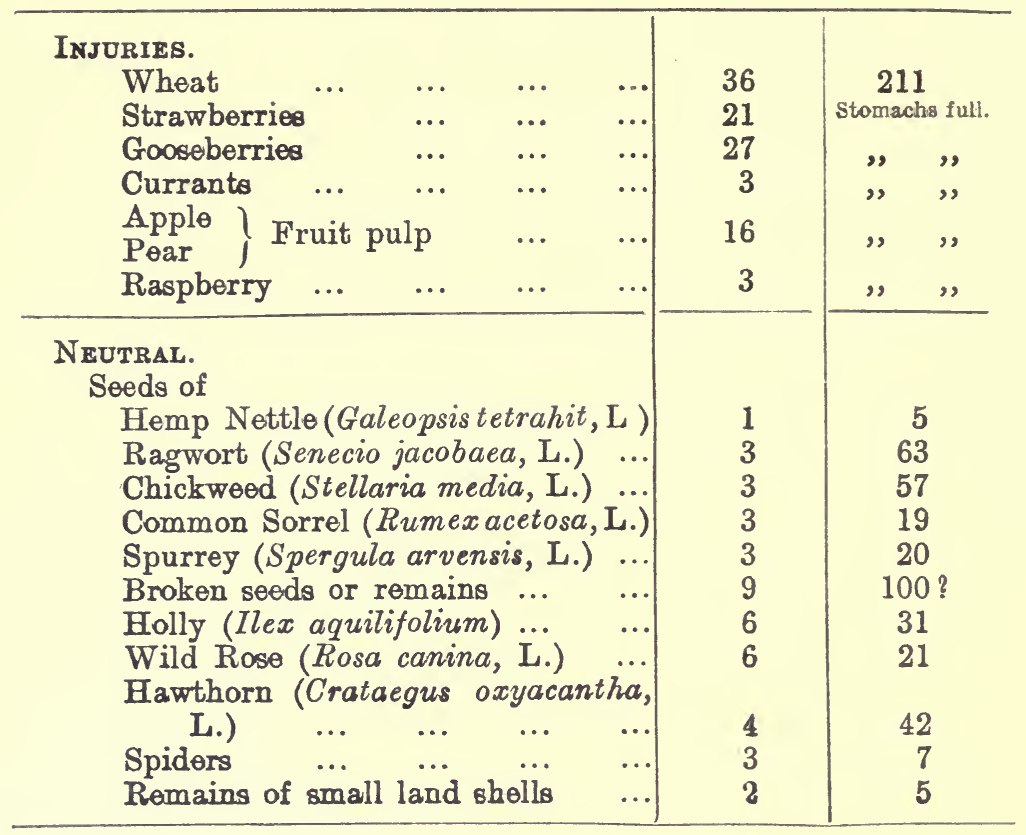

\section{Field Observations.}

Careful observations made in the field fully confirm all that has been written about this species as a pest to fruit-growers. In the early part of 1911 I saw a large acreage of strawberries seriously damaged, and currants and raspberries suffered in a like manner. At the close of the hot and dry summer of 1911 I observed these birds pecking ripe pears; when examined almost every fruit had one or two holes in.

\section{Food of Nestlings.}

An examination of the stomach contents of 23 specimens gave the following results:-remains of 17 earthworms and 9 slugs; 3 wireworms; fragments of wing-cases of beetles; large amount of vegetable matter present in all cases; bread and grain present in 7 cases.

\section{Examination of Faeces.}

A large number of droppings have been examined, most of which lend support to the view that this species eats a considerable amount of fruit. A few seeds of the common sorrel (Rumex acetosa, L.) were found in one case, and in sixteen cases out of thirty-seven there were minute bits of the wing-cases of beetles. 


\section{Conclusion.}

At the present time the blackbird is one of the most destructive birds that the fruit-grower has to contend with. Every effort should be made to reduce the number of these birds and to encourage the taking of their eggs.

\section{WHITETHROAT.}

\section{Sylvia cinerea, Bechstein.}

This interesting little warbler is frequently accused of causing damage in orchards and elsewhere, it has, therefore, been included in my list. Only seventeen specimens have been examined. The food contents of the stomachs being as set forth below.

Post-mortem Records.

\begin{tabular}{|c|c|c|}
\hline ARTICLE OF DIET. & $\begin{array}{c}\text { Times } \\
\text { occurred. }\end{array}$ & $\begin{array}{l}\text { Number } \\
\text { occurred. }\end{array}$ \\
\hline 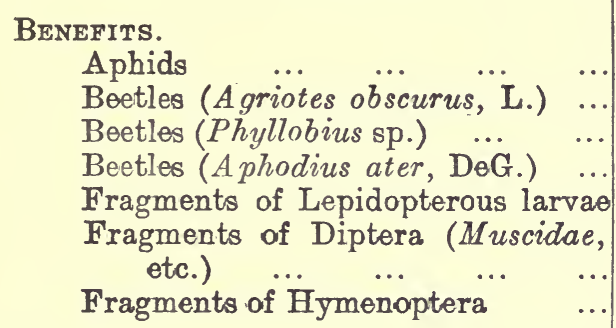 & $\begin{array}{l}5 \\
4 \\
9 \\
3 \\
5 \\
\\
4 \\
1\end{array}$ & $\begin{array}{c}42 \\
18 \\
27 \\
5 \\
80 ? \\
30 \\
4\end{array}$ \\
\hline $\begin{array}{l}\text { INJoRIEs. } \\
\text { Fragments of peas ... } \\
\text { Fragments of currants } \quad \ldots\end{array}$ & $\begin{array}{l}2 \\
2\end{array}$ & \\
\hline $\begin{array}{l}\text { Neutral. } \\
\text { Bits of leaves } \\
\text { Spiders }\end{array}$ & $\begin{array}{l}3 \\
1\end{array}$ & 2 \\
\hline
\end{tabular}

\section{Field Observations.}

In company with the Blackcap, I have observed this species feeding upon the Pea Louse (Macrosiphum pisi, Kalt.). The only injuries I have actually seen were to currants and raspberries, though it occasionally opens the pods of peas. 


\section{Conclusion.}

The bulk of the food consists of injurious insects. What little damage is done to peas and fruit is more than compensated for by the nature of the remaining food.

\section{BLACKCAP.}

\section{Sylvia atricapilla (Linn.).}

Essentially a summer visitant, the majority leaving this country in September, a few, however, undoubtedly remain over the winter.

Observations made in the field during the past few years tend to show that the numbers visiting this country are increasing, these birds are much commoner in our orchards to-day than ever they were.

Archibald (4) states: "Its food consists of spiders, aphides, and many other insects, sometimes captured on the wing, and of wild fruits, including blackberries and the berries of ivy, privet, and elder. It is also devoted to cultivated fruit, attacking currants, strawberries, raspberries and cherries, whilst, like the whitethroat, it opens pea-pods."

Smith (105) refers to this bird as follows: "A family of blackcaps in a cherry orchard commit grave havoc. They do not eat a quarter of the fruit they pick, and they are also very fond of raspberries and figs. It is the worst summer bird we have in the fruit plantations."

A well-known fruit-grower recently wrote me: "These birds do a large amount of damage to wall fruit; here we destroy all we can. If protected at all, or allowed to increase, it will become one of the worst orchard pests."

\section{Post-mortem Records.}

An examination of the stomach contents of 33 specimens gave the following results :-

\begin{tabular}{|c|c|c|c|c|}
\hline ARTICLE OF DIET. & & & $\begin{array}{c}\text { Times } \\
\text { occurred. }\end{array}$ & $\begin{array}{l}\text { Number } \\
\text { occurred. }\end{array}$ \\
\hline $\begin{array}{l}\text { BenEFITS. } \\
\text { Aphid remains } \ldots \\
\text { Lepidopterous larva } \\
\text { Beotle remains } \quad . .\end{array}$ & $\begin{array}{c}\cdots \\
\cdots \\
\cdots\end{array}$ & $\begin{array}{c}\cdots \\
\cdots \\
\cdots\end{array}$ & $\begin{array}{l}3 \\
6 \\
5\end{array}$ & $\begin{array}{r}? \\
20 \\
7\end{array}$ \\
\hline
\end{tabular}


INJURIES.

Seods or remains of Currant, Blackberry, Strawberry, Raspberry Fruit pulp ...

Remains of peas

Neutral.

Spiders

Seeds of ivy ...

Remains of elder seeds

\begin{tabular}{|c|c|}
\hline $\begin{array}{r}26 \\
17 \\
9\end{array}$ & $\begin{array}{c}\text { Stomachs full. } \\
\text { " } 32 "\end{array}$ \\
\hline $\begin{array}{l}4 \\
2 \\
3\end{array}$ & $\begin{array}{r}11 \\
8\end{array}$ \\
\hline
\end{tabular}

\section{Field Observations.}

I have observed this species feeding upon the Pea Louse (Macrosiphum pisi, Kalt.), but, unfortunately, it frequently causes considerable damage to the peas by opening the pods.

I have watched them pecking and picking cherries, strawberries and raspberries, to all of which they do considerable damage. I can fully bear out all that has been said by Smith and A rchibald as to the damage they occasion.

\section{Food of Nestlings.}

Four stomachs were examined, and contained seeds or remains of currants, strawberries and blackberries, and a considerable amount of fruit pulp.

\section{Conclusion.}

I should not adrocate any protection for this bird, as there is considerable likelihood, if it becomes at all numerous, of it being a very undesirable orchard pest. In small numbers it probably does more good than harm, but any attempt at protection will justify fruit-growers in taking vigorous measures for extermination.

\section{GREAT TIT.}

Parus major, Linn.

The most serious charge I have heard of against this bird is that it injures pears by pecking holes in them, and also of picking both apple and pear blossom to pieces.

Twenty specimens have been examined and the schedule of food contents is very interesting. 


\section{Post-mortem Records.}

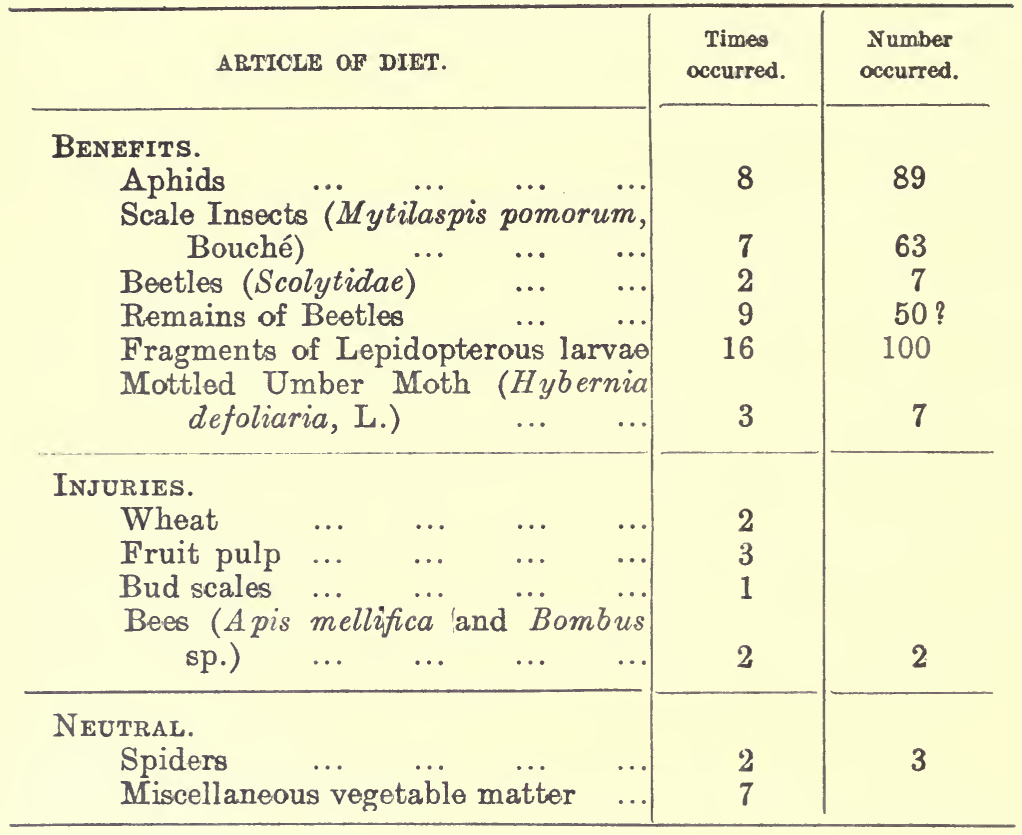

\section{Field Observations.}

In June, 1909, I watched a pair of these birds feeding in an apple orchard badly infested with the larvae of the Winter Moth (Cheimatobia brumata, Linn.). During an hour-and-a-half fortyseven visits were made to the trees and two or three caterpillars were taken each time. In another case I had an opportunity of watching a pair feeding in an apple tree covered with Mussel Scale and Woolly Aphis. For upwards of forty minutes the two birds were devouring these pests, only leaving the tree twice in an hour. There is no doubt but that they are one of the most valuable birds we have for controlling outbreaks of such moths as the Winter, Mottled Umber and March Moths.

\section{Food of Nestlings.}

I have not had any opportunity of examining nestlings, but $\mathrm{N}^{\top}$ ewstead (92) records that in a small rose nursery, near Chester, he watched a pair with a brood of eight young, and that 90 per cent. of the food brought in consisted of the larvae of Geometrid moths. 


\section{Conclusion.}

This species undoubtedly occasions a considerable amount of damage to apple and pear trees, but when one considers the nature of the food during the breeding season and that of the remainder of the year, it must be regarded as distinctly beneficial to the fruitgrower. By no other means could he obtain such results at so small a cost.

\section{BLUE TIT.}

Parus caeruleus, Linn.

This active little bird is frequently given a bad name by fruitgrowers, without pausing to consider the good that it does. I have had exceptional facilities of watching this bird in the field, in addition to which, thirty-eight post-mortems have been made of adults, ten of nestlings, and a considerable amount of work has been done on the examination of the freces.

This bird is often blamed for wantonly destroying buds, etc., in this connection, Archibald (4) states: "Whilst searching for its insect food it sometimes appears exceedingly and wantonly mischievous. It may be seen tearing the buds or blossoms of fruit trees to pieces in a reckless manner and most capriciously, for, after a cursory survey, it will leave one tree and then subject to a prolonged investigation another to all appearances exactly similar. 'There is, however, method enough in this procedure, for it is not the buds or blossoms themselves that are so eagerly sought for, but the eggs or grubs of insects with which they are so often infested. From their minute size these pests escape human observation, but the keen vision of the tit enables it to detect them. It is scarcely necessary to add that the insects, if unmolested, would not only destroy the buds and blossoms, but would produce a countless progeny as rapacious as themselves. I witnessed, not long ago, a good instance of this apparently destructive propensity. Some blue tits were busily engaged in a willow, stripping the catkins from the twigs, and showering them down on to the road, chuckling to themselves at intervals with evident delight. The whole performance looked as if it were a piece of exuberant mischief, but on examining some of the catkins scattered on the road, I noticed dark-brown channels in their centres, and on gathering further specimens from the willow, the secret of the tits' satisfaction was revealed. For in many of them a little white grub was ensconced, eating out the core of the catkin. It was impossible to resist the idea that chuckles of exceptional vivacity heralded the discovery of grubs of more than ordinary dimensions." 
Smith (105) states: "He does some mischief in the autumn by pecking apples and pears, but all the rest of the year he is looking for small insects and their eggs."

\section{Post-mortem Records.}

\begin{tabular}{|c|c|c|c|}
\hline \multicolumn{2}{|l|}{ ARTICLE OF DIET. } & $\begin{array}{c}\text { Times } \\
\text { occurred. }\end{array}$ & $\begin{array}{l}\text { Number } \\
\text { occurred. }\end{array}$ \\
\hline $\begin{array}{l}\text { BENEFITs. } \\
\text { Aphids } \ldots \\
\text { Scale Insects } \ldots \\
\text { Apple blossom Weevil }(A \\
\text { pomorum, L.) } \ldots \\
\text { Fragments of Beetles } \\
\text { Fragments of Lepidopter } \\
\text { Fragments of Moths (Tir } \\
\text { Fragments of Dipterous } 1 \\
\text { Gall-making insects }(C y\end{array}$ & $\begin{array}{cr}\ldots & \ldots \\
\ldots & \ldots \\
\text { thonomus } \\
\ldots & \ldots \\
\ldots & \ldots \\
\text { ous } & \text { larvae } \\
\text { eina) } & \ldots \\
\text { arvae } & \ldots \\
\text { nips, etc.) }\end{array}$ & $\begin{array}{r}6 \\
16 \\
3 \\
7 \\
20 \\
3 \\
4 \\
8\end{array}$ & $\begin{array}{c}150 \\
500 ? \\
19 \\
100 ? \\
250 ? \\
7 \\
30 \\
29\end{array}$ \\
\hline $\begin{array}{l}\text { INJURIES. } \\
\text { Fruit pulp } \ldots \\
\text { Fragments of wheat } \\
\text { Fragments of bud scales } \\
\text { Particles of apple rind }\end{array}$ & $\begin{array}{l}\cdots \\
\ldots \\
\ldots \\
\ldots\end{array}$ & $\begin{array}{l}7 \\
4 \\
5 \\
3\end{array}$ & \\
\hline $\begin{array}{l}\text { Neutral. } \\
\text { Fruit of Birch } \\
\text { Bits of grass ... } \\
\text { Miscellaneous vegetable } n \\
\text { Spiders } \quad \ldots .\end{array}$ & $\begin{array}{cc}\ldots & \ldots \\
\ldots & \ldots \\
\text { latiter } & \ldots \\
\ldots & \ldots\end{array}$ & $\begin{array}{l}4 \\
1 \\
6 \\
4\end{array}$ & 11 \\
\hline
\end{tabular}

\section{Field Observations.}

The only actual injury I have observed this bird commit is pecking holes in ripe pears, on the other hand I have watched it for hours feeding on various species of Scale Insects and Aphids. Although I have kept a careful watch I have never seen them eat peas, and in no case that has been sent in to me, where the particulars furnished have stated: "shot while eating peas," have I found any trace of peas, on the other hand the stomachs have usually been full of insects.

\section{Food of Nestlings.}

Ten post-mortems have been made. The food consisted entirely of fragments of small Lepidopterous larvae and aphids. In no case was vegetable matter of any kind found. 


\section{Examination of Faeces.}

The examination of a large number of droppings lends support to the view that this species is not concerned in the distribution of weed seeds, and that the bulk of its food is of animal nature. The mouth parts of insects and fragments of the wing-cases and legs were met with in large numbers.

\section{Conclusion.}

In spite of all that has been chronicled against this bird, I am of opinion that it is distinctly beneficial. The harm it does is comparatively insignificant when compared with the great benefits it confers.

\section{WREN.}

Troglodytes parvulus, K. L. Koch.

This species is included as I had four adult specimens sent in and eight nestlings. The wren is essentially an insectivorous bird; there are numerous observations on record supporting this statement, but so far as I am aware these are the first published records obtained from post-mortem examinations.

Post-mortem Records.

\begin{tabular}{|c|c|c|}
\hline ARTICLE OF DIET. & $\begin{array}{c}\text { Times } \\
\text { occurred. }\end{array}$ & $\begin{array}{l}\text { Number } \\
\text { occurred. }\end{array}$ \\
\hline $\begin{array}{l}\text { BENEFITs. } \\
\text { Aphids } \quad \ldots \text {... } \\
\text { Fragments of Lepidopterous larvae } \\
\text { (Geometers) } \ldots . . . \\
\text { Fragments of Leather Jackets }\end{array}$ & $\begin{array}{l}4 \\
4 \\
3\end{array}$ & $\begin{array}{l}20 \\
58 \\
22\end{array}$ \\
\hline $\begin{array}{l}\text { Neutral. } \\
\text { Broken seeds }\end{array}$ & 2 & 11 \\
\hline
\end{tabular}

\section{Field observations.}

A pair of birds nesting close to my house were carefully watched, and counts were made of the number of visits the parents paid to the nest. Between 2 and 3 p.m., 38 visits were made; between 3 and 4 p.m., 36 ; and between 6 and 7 p.m., 29 . On all these occasions Crane Flies constituted the bulk of the food. 


\section{Food of Nestlings.}

The stomach contents of the eight nestlings examined, consisted entirely of Crane Flies and the larvae of some small moth (Geometer).

\section{Conclusion.}

This bird is distinctly beneficial, and should be protected.

\section{GREENFINCH.}

\section{Ligurinus chloris (Linn.).}

Opinions as to the economic status of the greenfinch differ very widely. Archibald (4) speaks of it as feeding "largely on seeds, including corn and turnip seed. When too numerous both this species and the chaffinch do considerable damage, and it may be necessary to keep them within bounds. It is worthy of remark in passing that an undue increase of small birds is the inevitable result of exterminating such of their natural enemies as the sparrow-hawk, jay, and magpie. The greenfinch co-operates with other small birds in devouring the seeds of such weeds as the dandelion, corn marigold, dock, plantain, goosegrass, corn crowfoot, charlock, knot-grass, and wild vetch. Its young are chiefly fed on insects and a few seeds, and immense quantities of moths, flies, caterpillars, and other pests are captured for their sustenance."

Slater (104) states that it "is only occasionally mischievous, when it attacks newly-sown garden seeds. . . . . the mischief it does is triflng on the whole."

Hooper (68) sums up its character more faithfully, he writes: "This strongly built and noisy bird needs, like the chaffinch, no protection; if anything, it is more destructive, and for a longer period. The adult birds, like the sparrow, eat but few insects; they are sometimes very destructive to sprouting crops. A field at Halstead, Kent, sowed with milled sainfoin had to be ploughed up owing to flocks of greenfinches taking all the seed. It eats grain and large quantities of weed seeds, of which it also probably distributes many. Mr. L. H. Page, of Sittingbourne, says it eats the seeds of strawberries when ripe. It does not eat fruit, but accompanies the sparrow destroying buds; it also picks blooms to pieces. It is terribly destructive in pulling hop flowers to pieces to get at the seeds, and comes in large flocks and litters the ground with the flower bracts of the hop."

Theobald (109) states that this bird is a great destroyer of fruit blossoms.

Forty-two adults and thirteen nestlings have been examined. 


\section{Post-mortem Records.}

\begin{tabular}{|c|c|c|}
\hline ARTICLE OF DIET. & $\begin{array}{c}\text { Times } \\
\text { occurred. }\end{array}$ & $\begin{array}{l}\text { Number } \\
\text { occurred. }\end{array}$ \\
\hline BeNEFITS. & & \\
\hline $\begin{array}{l}\text { INJuRIEs. } \\
\begin{array}{lllll}\text { Wheat } & \ldots & \ldots & \ldots & \ldots \\
\text { Turnip seed } & \ldots & \ldots & \ldots & \ldots \\
\text { Fruit buds } & \ldots & \ldots & \ldots & \ldots\end{array}\end{array}$ & $\begin{array}{r}29 \\
1 \\
2\end{array}$ & $\begin{array}{r}230 \\
23\end{array}$ \\
\hline $\begin{array}{l}\text { Neutral. } \\
\text { Seeds of } \\
\text { Mouse-eared Chickweed (Cerastium } \\
\text { triviale, Linn.) } \\
\text { Chickweed (Stellaria media, L.) }\end{array}$ & $\begin{array}{r}4 \\
8 \\
4 \\
4 \\
3 \\
2 \\
\\
1 \\
23 \\
37\end{array}$ & $\begin{array}{r}92 \\
800 \\
18 \\
103 \\
12 \\
11 \\
5\end{array}$ \\
\hline
\end{tabular}

\section{Field Observations.}

I can corroborate all that Hooper and Theobald say with respect to the habits of this bird, in addition to which, in kitchen gardens, it is a most destructive pest.

\section{Food of Nestlings.}

Of the thirteen nestlings examined only nine contained the remains of insects, the contents of the remaining four consisting of broken fragments of some seeds only. In all cases these fragments were present sometimes in the form of a starchy pulp. Remains of fourteen small caterpillars and three spiders were also present, and the wings of nine small Dipterous flies.

Examination of Faeces.

I have elsewhere shown (36a) that by placing the droppings upon sterilised soil, various species of weeds were cultivated. Thirty-eight droppings thus treated produced fifty-two plants referable to the following species: Charlock, curled dock, ribwort, dandelion, knotweed, goosegrass, and corn marigold. 


\section{Conclusion.}

The greenfinch is a very serious enemy of freshly sown and germinating seed, and also helps in distributing the seeds of various weeds. In many parts of the country it is far too numerous, and should be destroyed.

\section{GOLDFINCH.}

Carduelis elegans, Stephens.

I have failed to find any reference to this bird so far as postmortem records are concerned. Neither Newstead (92) nor Florence (47) make mention of it.

Archibald (4) states that its food "consists of the seeds of various weeds, including the thistle, hardhead or horseknop, dandelion, ragwort, groundsel, teasel, burdock, chickweed, and plantain. Like the chaffinch, it picks out the small seeds from fir cones. It also attacks the twigs of lime and willow, stripping off the outer bark for the sake of the inner tissue. Caterpillars, beetles, and other insects are destroyed by it in summer, and it is probable that the young are partly fed on aphides."

Owing to that pernicious pest, the bird-catcher, who seems immune from the Law, this bird is by no means so common in the Midland counties as formerly.

\section{Post-mortem Records.}

Fifty-four specimens have been examined.

\begin{tabular}{|c|c|c|}
\hline ARTICLE OF DIET. & $\begin{array}{c}\text { Times } \\
\text { occurred. }\end{array}$ & $\begin{array}{l}\text { Number } \\
\text { occurred. }\end{array}$ \\
\hline 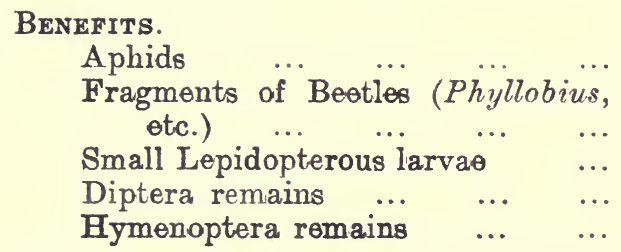 & $\begin{array}{r}17 \\
9 \\
23 \\
11 \\
2\end{array}$ & $\begin{array}{r}80 \\
\\
33 \\
138 \\
70 \\
9\end{array}$ \\
\hline $\begin{array}{l}\text { INJURIES. } \\
\text { Broken buds ... }\end{array}$ & 7 & \\
\hline
\end{tabular}


Neutral.

Seeds of

Burdock (Arctium lappa, L.)

Knapweed (Centaurea nigra, L.) ... Spear Thistle (Cnicus lanceolatus, Hoffm.)

Ragwort (Senecio jacobaea, L.) $\quad \ldots$

Dandelion (Taraxacum officinale,

Wigg.) $\ldots \quad \ldots \quad \ldots \quad \ldots$

Ribwort (Plantago lanceolata, L.)

Chickweed (Stellaria media, L.) ...

Wild Teazle (Dipsacus sylvestris, L.)

Miscellaneous vegetable matter, not identifiable

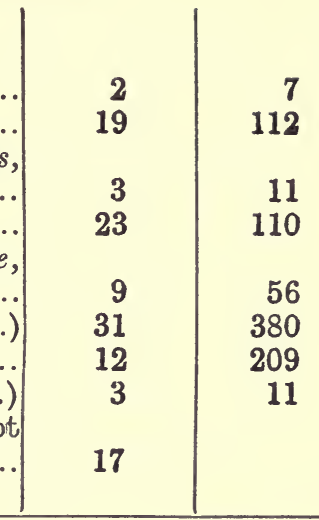

\section{Field Observations.}

I have frequently observed this bird on fruit trees, but have never seen it do any harm.

\section{Conclusion.}

The worst that can be brought against the species is, I think, that it probably aids in the distribution of weed seeds, otherwise it is distinctly beneficial.

\section{HOUSE SPARROW.}

\section{Passer domesticus (Linn.).}

The evidence that has been brought forward, and upon which this bird has been convicted is not altogether satisfactory.

Gurney (57, 58), Russell (58), Coues (58) Miller (58), Barrows (8), Tegetmeier (107), Ormerod (95), and others have referred to this species in the strongest deprecatory language. Gurney (op. cit.) states that " about 75 per cent. of an adult sparrow's food during its life is corn of some kind. The remaining 25 per cent. may be roughly divided as follows:-

$\begin{array}{lcccc}\text { Seeds of weeds } & \ldots & \ldots & 10 & \text { per cent. } \\ \text { Green Peas } \ldots & \ldots & \ldots & 4 & , \\ \text { Beetles } \ldots & \ldots & \ldots & 3 & , \\ \text { Caterpillars } & \ldots & \ldots & 2 & , \\ \text { Insects which fly } & \ldots & \ldots & 1 & , \\ \text { Other things } & \ldots & \ldots & 5 & ,\end{array}$


In young sparrows not more than 40 per cent. is corn, while about 40 per cent. consists of caterpillars, and 10 per cent. of small beetles. This is up to the age of sixteen days."

Gurney's statement is founded upon six hundred and ninetyfour dissections, made by various people, in various places.

Archibald (4) sums up the question very fairly, he writes: "It is evident, therefore, that there are two sides to the "sparrow question,' and many good naturalists have been unable to decide which way the balance inclines. It can, however, scarcely be denied that sparrows are almost everywhere too abundant, and, in all probability, if their numbers were greatly reduced, other more attractive and less mischievous birds would be equally efficacious in keeping the ravages of insects within bounds."

Newstead (92) does not discuss this species in his paper. Florence (47) examined thirty-five specimens, thirty of which contained grain, one seeds, one bread, one remains of an insect, and in three the stomachs were empty.

In view of the above statements it seemed desirable to re-open the question of the nature of the food of this so-called "avian rat." Early in 1910 I commenced to work upon this species, completing by May, 1912, four hundred and four post-mortems of adults, fortytwo of nestlings, and the examination of numerous droppings.

Of the four hundred and four specimens two hundred and seven were shot in or near to orchards or in fruit-growing districts; one hundred and thirty-eight from agricultural districts, and fiftynine from suburban districts. The nature of the food for each series is given separately.

\section{Post-mortem Records.}

1. From Fruit-growing Distriots (207).

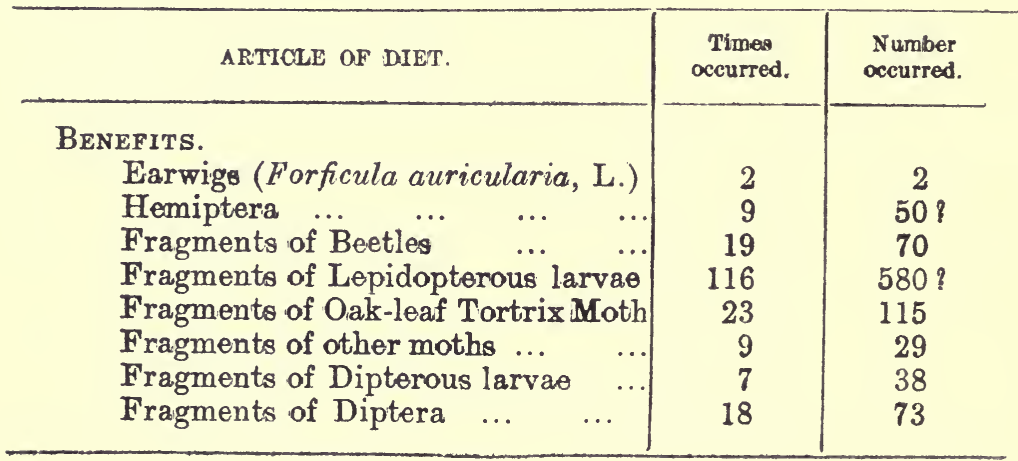




\begin{tabular}{|c|c|c|}
\hline 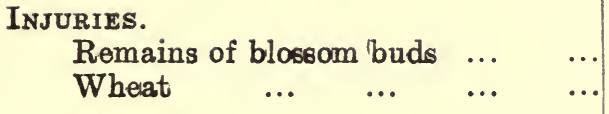 & $\begin{array}{l}23 \\
27\end{array}$ & 105 \\
\hline 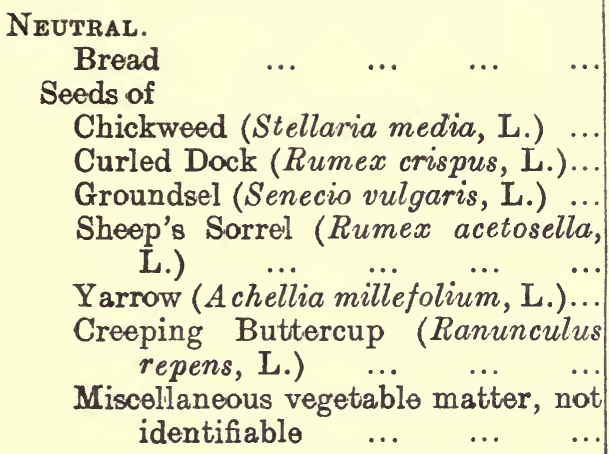 & $\begin{array}{r}93 \\
47 \\
21 \\
15 \\
\\
12 \\
5 \\
\\
23 \\
54\end{array}$ & $\begin{array}{r}212 \\
80 \\
83 \\
64 \\
29 \\
57\end{array}$ \\
\hline
\end{tabular}

2. From Agricultural Districts (138).

\begin{tabular}{|c|c|c|c|c|}
\hline ARTICLE OF DIET. & & & $\begin{array}{c}\text { Times } \\
\text { occurred. }\end{array}$ & $\begin{array}{l}\text { Number } \\
\text { occurred. }\end{array}$ \\
\hline $\begin{array}{l}\text { BENEFITS. } \\
\text { Remains of Beetles ... } \\
\text { Fragments of Insect lar }\end{array}$ & ae & $\begin{array}{l}\ldots \\
\ldots\end{array}$ & $\begin{array}{l}5 \\
7\end{array}$ & $\begin{array}{l}23 \\
43\end{array}$ \\
\hline $\begin{array}{l}\text { INJURIES. } \\
\text { Wheat } \\
\text { Remains of other grain }\end{array}$ & $\begin{array}{l}\ldots \\
\ldots\end{array}$ & $\begin{array}{l}\ldots \\
\ldots\end{array}$ & $\begin{array}{r}115 \\
43\end{array}$ & $1741 ?$ \\
\hline 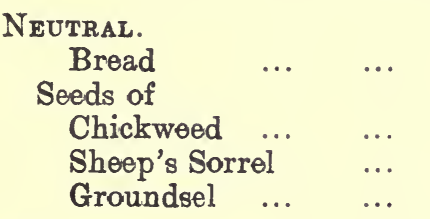 & $\begin{array}{l}\cdots \\
\cdots \\
\cdots \\
\cdots\end{array}$ & $\begin{array}{l}\cdots \\
\cdots \\
\cdots\end{array}$ & $\begin{array}{l}27 \\
56 \\
29 \\
42\end{array}$ & $\begin{array}{l}320 \\
110 \\
220\end{array}$ \\
\hline
\end{tabular}




\section{From Suburban Districts (59).}

\begin{tabular}{|c|c|c|}
\hline ARTIOLE OF DIET. & $\begin{array}{c}\text { Times } \\
\text { occurred. }\end{array}$ & $\begin{array}{l}\text { Number } \\
\text { occurred. }\end{array}$ \\
\hline $\begin{array}{l}\text { BENEFITS. } \\
\text { Aphids } \quad \ldots \quad \ldots \\
\text { Lepidopterous larvae } \\
\text { Diptera (Tipula sp.) } \\
\text { Remains of Dipterous larvae }\end{array}$ & $\begin{array}{r}2 \\
29 \\
7 \\
15\end{array}$ & $\begin{array}{l}12 \\
64 \\
21 \\
70\end{array}$ \\
\hline 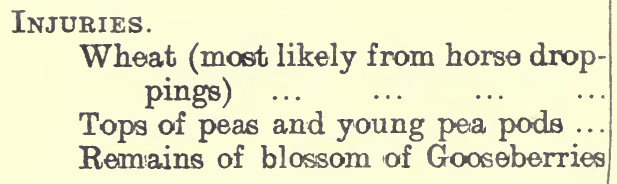 & $\begin{array}{r}9 \\
16 \\
5\end{array}$ & 69 \\
\hline $\begin{array}{l}\text { Neutral. } \\
\text { Bread and household refuse } \\
\text { Seeds of } \\
\begin{array}{llll}\text { Chickweed } & \ldots & \ldots & \ldots \\
\text { Curled Dock } & \ldots & \ldots & \ldots \\
\text { Groundsel } & \ldots & \ldots & \ldots\end{array}\end{array}$ & $\begin{array}{l}51 \\
33 \\
20 \\
32\end{array}$ & $\begin{array}{r}201 \\
95 \\
300\end{array}$ \\
\hline
\end{tabular}

It will thus be seen that in the specimens obtained from fruitgrowing districts the good done by these birds far outweighed the harm, whereas in the agricultural districts the food was mainly wheat and other grains, whilst in the suburban districts a very mixed diet was found.

By keeping separate records of the stomach contents of the birds under these three classes, a truer statement of the actual food, I believe, has been obtained.

\section{Field Observations.}

I have watched this species feeding upon the larvae of the Winter Moth (Cheimatobia brumata, Linn.), and also upon the small Tortrix larvae so plentiful upon apple trees. In one case I observed them picking apple-blossom to pieces to get at the larvae of a Tortrix moth (Tortrix ribeana, Hb.), but I must confess that they did quite as much harm as the larvae would have done.

Slugs they are not particularly fond of excepting those newly hatched, they also eat up the eggs of slugs. 


\section{Food of Nestlings.}

I have elsewhere (34) shown that during the breeding season between 220 and 260 visits are daily paid to the nest by the parent birds. "Observations were made on various dates of 84 visits to the nest, and the following were identified:-12 larvae of the Winter Moth (Cheimatobia brumata, Linn.); 15 beetles (Phyllobius, sp.); 3 ladybird beetles; large number of small Dipterous larvae; number of small Dipterous flies; 2 spiders; on 23 occasions bread, potato, and other kitchen refuse."

Post-mortems made of forty-two nestling birds gave the following results :-

\begin{tabular}{|c|c|c|}
\hline ARTICLE OF DIET. & $\begin{array}{l}\text { Times } \\
\text { occurred. }\end{array}$ & $\begin{array}{l}\text { Number } \\
\text { occurred. }\end{array}$ \\
\hline 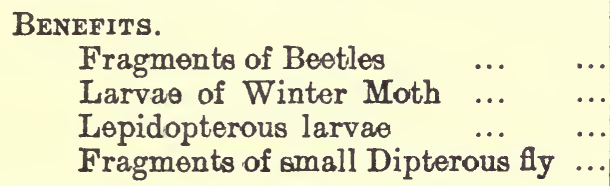 & $\begin{array}{l}8 \\
7 \\
2 \\
9\end{array}$ & $\begin{array}{r}19 \\
21 \\
3 \\
33\end{array}$ \\
\hline $\begin{array}{l}\text { INJURIEs. } \\
\text { Wing-cases of Ladybird Beetle }\end{array}$ & 2 & 7 \\
\hline $\begin{array}{l}\text { Neurral. } \\
\text { Spiders } \quad \ldots \text {... ... ... } \\
\text { Bread, meat, rice grains, and mis- } \\
\quad \text { cellaneous vegetable matter ... }\end{array}$ & $\begin{array}{r}3 \\
39\end{array}$ & 4 \\
\hline
\end{tabular}

Examination of Faeces.

An experiment made on fifty-four droppings which were placed in sterilised soil (36a), resulted in the cultivation of one hundred and thirty-three weed-plants referable to seven species; whilst from a careful examination made of thirty-five droppings the following perfect seeds were obtained :-

Ribwort, 22; Buttercup, 14; Dandelion, 3; Chickweed, 7 ; Sheep's Sorrel, 9; Yarrow, 8; Dock, 8; Daisy, 4; and Groundsel, 10.

Undoubtedly sparrows are very active distributors of injurious weed-seeds.

\section{Conclusion.}

The sparrow has been allowed to increase to such an extent that it has become one of the worst bird pests we have, but if it were reduced to such numbers as to be no commoner than say, the 
robin, I believe the good it would do would more than compensate for the harm. At present the attitude of all farmers must be one of extermination, and to this end it would seem very desirable that the use of poisoned grain should be' permitted.

\section{CHAFFINCH.}

\section{Fringilla coelebs, Linn.}

Apart from what I wrote in 1905 (30) this bird has generally been regarded as beneficial. Archibald (4) states that it "feeds largely on insects, and brings up its young almost entirely on an insect diet. . . . It also eats beechmast and quantities of small seeds, amongst them those of many noxious weeds. Some of the seeds are shelled before being eaten, but others are swallowed without any such preparation. . . . Though it eats corn, it is only when its numbers are very great that it causes any serious loss to the farmer by so doing, but at times it does considerable damage to young turnips, radishes, and similar crops."

Smith (105) writes: "The chaffinch is not generally considered a bad bird, but he is a great disbudder of fruit, gooseberries, currants, and plums, especially after a frost, when these birds will be found in twos and threes all over the plantation, eating the buds. They are responsible for much of the damage done to plums, cherries, gooseberries, and currants, by squeezing the blossom to extract the honey in it; while they are also very fond of lady-birds and their larvae, clearing off large quantities of these useful insects."

Florence (47) who has examined the stomach contents of thirtyfour birds, summarises the contents as follows: " 31 contained grain ; 1 , Indian corn ; 30 , seeds of weeds ; 2 , decomposed vegetable matter; 2 , insect remains."

\section{Post-mortem Records.}

Post-mortems have been made of sixty-eight adult and twelve nestling birds, with the following results:-

\begin{tabular}{|c|c|c|}
\hline ARTICLE OF DIET. & $\begin{array}{c}\text { Times } \\
\text { occurred. }\end{array}$ & $\begin{array}{l}\text { Number } \\
\text { occurred. }\end{array}$ \\
\hline $\begin{array}{l}\text { Benefits. } \\
\text { Aphids } \ldots \ldots \\
\text { Small Lepidopterous larvae }\end{array}$ & $\begin{array}{l}19 \\
22\end{array}$ & $\begin{array}{l}189 \\
211\end{array}$ \\
\hline
\end{tabular}




\begin{tabular}{|c|c|c|}
\hline 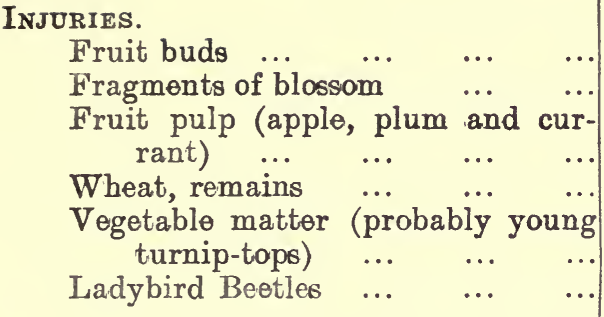 & $\begin{array}{r}29 \\
7 \\
\\
11 \\
27 \\
\\
3 \\
6\end{array}$ & 19 \\
\hline 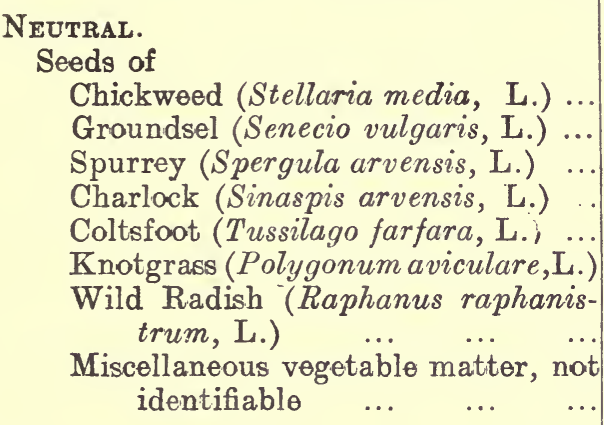 & $\begin{array}{r}19 \\
23 \\
3 \\
28 \\
9 \\
27\end{array}$ & $\begin{array}{r}283 \\
150 \\
11 \\
286 \\
39 \\
380\end{array}$ \\
\hline
\end{tabular}

\section{Field Observations.}

Personal observation in the field and orchard convinces me of the harm this bird does. Apart from what it eats, it occasions considerable damage in the orchard by destroying blossom buds.

\section{Food of Nestlings.}

Twelve post-mortems showed the food to consist almost entirely of the larvae of the Winter Moth (Cheimatobia brumata, Linn.), and another small Geometrid larvae. In five stomachs there were beetle remains, and in one the wings of aphids.

\section{Conclusion.}

For two months or more great harm is done by this bird to sprouting corn, and during the summer it does considerable damage in the orchard. The species is much too plentiful, and requires reducing in numbers. 


\section{LINNET. \\ Linota cannabina (Linn.).}

I have from time to time received complaints about this bird, it has, therefore, been included in the present investigation.

Archibald (4) states that when very abundant they "do considerable damage to turnips, rape, and similar crops, by feeding on their seed, which they attack when newly sown, and also, where the crop is grown for seed, at harvest time. With this exception they are harmless, for the amount of corn taken by them is comparatively trifling. The seeds of flax and hemp are eagerly sought by the linnet, and it devours quantities of weed-seeds, including those of the dock, sorrel, knotgrass, charlock, groundsel, ragwort, chickweed, and plants allied to the deadnettle. Numerous insects and a few berries also form part of its diet, and it is, therefore, a bird which may well be encouraged, except in occasional circumstances."

Theobald (109) states: "it is often harmful in hop gardens with the greenfinch. Where present in large numbers it becomes a great pest, feeding on turnip, swede, rape, cabbage seed, and also where the crop is grown for seed. Flax and hemp are especially destroyed."

Newstead (92) examined only two specimens, and Florence none.

My own work embraces thirty-nine post-mortems of adult, and ten of nestling birds.

Post-mortem Records.

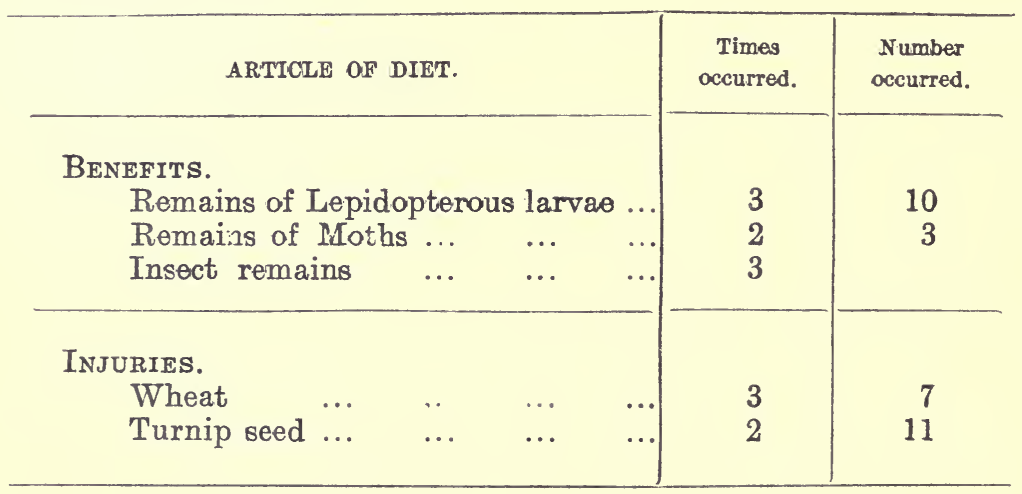


Neutral.

Seeds of

Charlock (Sinaspis arvensis, L.) ... Chickweed (Stellaria media, L.) ... Groundsel (Senecio vulgaris, L.) ... Ragwort (Senecio jacobaea, L.) ... Mouse-ear Hawkweed (Hieracium

$\begin{array}{cccc}\text { pilosella, L.) } & \ldots & \ldots & \ldots \\ \text { Self-heal (Prunella vulgaris, L.) } & \ldots\end{array}$ Knotgrass (Polygonum aviculare, L.) ...

Curled Dock (Rumex crispus, L.)... Common Sorrel (Rumex acetosa, L.) Miscellaneous vegetable matter

\begin{tabular}{r|r|r} 
& & \\
.. & & \\
.. & 23 & 360 \\
.. & 5 & 58 \\
.. & 15 & 148 \\
$m$ & 4 & 42 \\
.. & 2 & 14 \\
.. & 2 & 28 \\
\hline. & & \\
.. & 7 & 23 \\
.. & 6 & 42 \\
.. & 9 & 111 \\
& 12 &
\end{tabular}

\section{Field Observations.}

I have watched large flocks feeding upon the seeds of charlock, groundsel, and dock, also in fruit trees, but the nature of the food I was unable to decide. They seemed very busy in the cracks of broken bark, etc., probably the eggs of some insects formed the food supply.

\section{Food of Nestlings.}

The ten nestlings examined showed that the food consisted of the larvae of some small moth, a few Dipterous larvae, spiders, aphids, and in two cases there were beetle remains.

\section{Conclusion.}

The linnet is a harmless bird, but it would be well to keep a check upon it in districts where it has increased very rapidly in recent years.

\section{BULLFINCH.}

\section{Pyrrhula europaea, Vieillot.}

Considerable diversity of opinion exists both amongst fruitgrowers and ornithologists as to whether this bird should be included amongst those that are injurious or beneficial, thus in a paper read before the Farmers' Club on April 3rd, 1905, Slater (104) writes as follows: "The Bullfinch.-A perfectly harmless and altogether desirable neighbour, as it feeds on hedge fruits, seeds of dock, thistle, and other weeds, except in February and March, when it does serious damage, if not watched, to the gooseberry, 
plum and damson buds. It is never necessary, however, to shoot it-a little stone-throwing, or, better still, catapulting, is quite enough. Shooting at it injures the trees and bushes quite as much as the bullfinches do." That such an opinion is contrary to facts, $I$ hope to prove in the following pages.

Hooper (68) states: "The Bullfinch, which has been briefly described as not having one redeeming feature save his appearance, seems to be somewhat local, and is probably most plentiful near woods. When numerous in a fruit-growing distriet, it seems that for self-protection they must be killed, as the damage they do to the buds is a very serious matter, and often they wantonly destroy the buds without even eating them. They commence soon after Christmas, when the first spell of frost has sweetened the swollen buds, and continue eating them until the buds expand into leaves. The worst time is the beginning of March."

The bullfinch feeds on buds, especially of plants that bear fruit, such as plums, damsons, cherries, gooseberries, currants, apples, and pears; it shows a special liking for Greengage, Black Diamond, Purple Gage, and Early Rivers Plums, which it will first attack in an orchard. It shows a preference for certain varieties of gooseberries, and amongst apples the buds of 'Councellor' are favourites. It also attacks the buds of hawthorn, blackthorn, birdcherry, larch, and beech. Smith (105) says that: "The bullfinches are the most destructive birds the fruit-grower has to contend against. They rove about, in families of five or six, through the winter. A family will come into a fruit tree, and stay there until they have destroyed all the buds-both bloom and fruit buds. They usually begin with 'May Duke' cherries, in the early autumn, and keep on with plums, gooseberries, currants, and medlars; ending, in late spring, with black currants and apples. For six months they live almost entirely on fruit buds; the other six months on seeds of various wild plants."

This, the statement of a careful observer, presents the bullfinch in a rather different, but truer light.

Archibald (4) states: "Most unfortunately, this handsome finch destroys the buds of fruit trees and diminishes the yield to a serious extent. It takes very few insects."

Newstead (92) in his work on the "Food of some British Birds," writes: "The serious nature of the havoc which this bird commits in destroying the buds of various fruit trees is so generally known that it would be superfluous to add to the already extensive literature on this subject."

Testimony from actual fruit-growers is interesting, and from a large number of letters I select the following statements:-

"Are a very serious pest in our orchards, without any redeeming feature save their appearance.-(A. 327/11). 
"The annual loss sustained by us must be upwaros of $£ 100$ from these destructive birds."-(A. 411/11).

"From December to the end of April these birds occasion a considerable amount of damage to our fruit-trees, and during the remainder of the year are active in distributing the seeds of various weeds. They should certainly be destroyed."-(A. 429/11).

"Our plums (Greengage and Black Diamonds) have suffered terribly from these birds. In some cases the whole of the fruitbuds have been destroyed. We are sending ten birds shot to-day for examination."-(A. 512/10).

\section{Post-mortem Records.}

I have made post-mortem examinations of three hundred and eight specimens, received from Worcestershire, Warwickshire, Staffordshire and Hereford, in addition to one hundred and seventy-six examined in the months of April and May in 190?, 1908, 1909 and 1910, making a total of four hundred and eightyfour.

By far the larger number of fruit-growers, interviewed or written to, in the above-mentioned counties, agree that during the past six or seven years there has been a great increase in the number of these birds, and they would welcome any measures for aiding in considerably reducing their numbers.

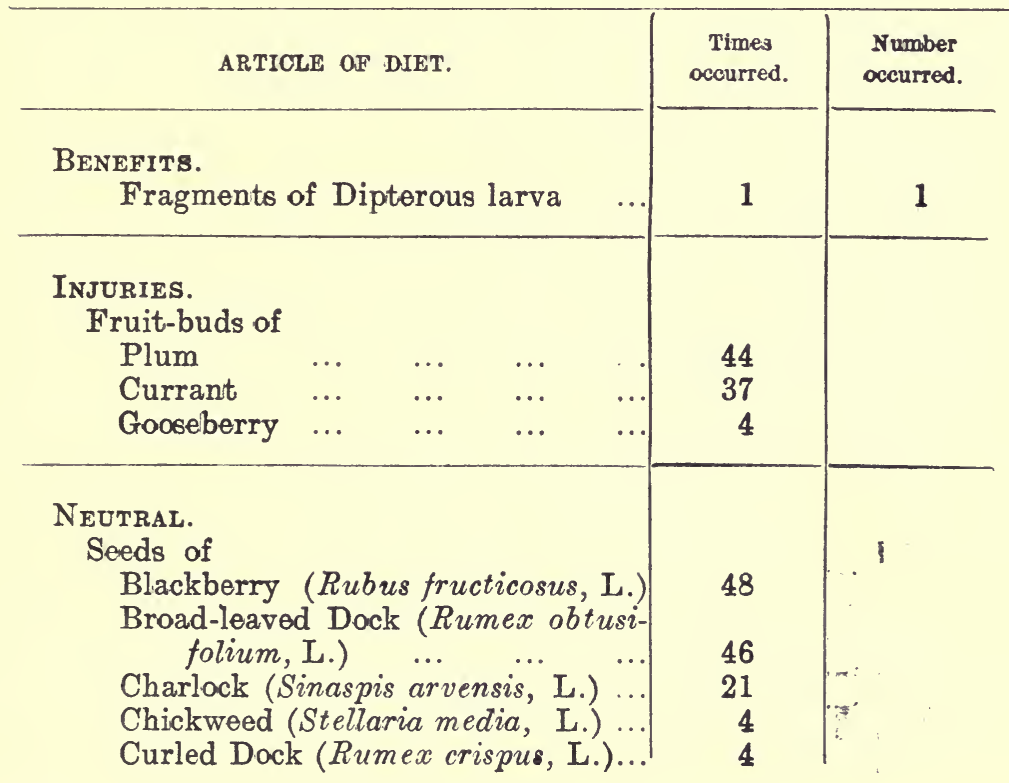




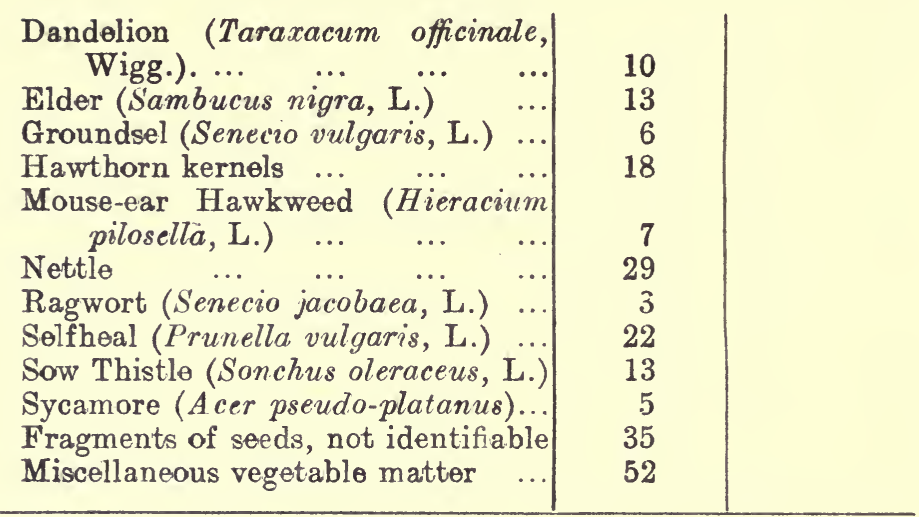

\section{Field Observations.}

During the five months, January to May, the food consists largely of fruit-buds and fruitlets, and in addition to those which are actually eaten, an equal, or even larger, number are wantonly destroyed by this bird. I have watched them for hours on plum trees destroying the buds wholesale, and similarly on currants.

\section{Food of Nestlings.}

An examination of thirteen specimens showed that the stomach contents consisted largely of small Lepidopterous larvae and the remains of some small moth, together with beetle remains and those of some Dipterous flies. There were also remains of fruit in five stomachs and leaf-buds in two.

\section{Conclusion.}

Founded largely upon observations in the field, I cannot arrive at any other conclusion than that the bullfinch is, for quite half the year, most destructive in fruit orchards, causing considerable losses to growers, which far outweigh any little good it may do in keeping down the spread of weeds. Indeed, its value in this respect is extremely doubtful, for it certainly helps in the distribution of such weeds as the dandelion, dock, groundsel, ragwort, charlock, etc. In all fruit-growing districts it should be destroyed.

\section{YELLOW BUNTING.}

Emberiza citrinella, Linn.

Of recent years there has been a considerable increase of this bird, particularly so in certain districts. My own investigations were made some years ago, and, therefore, are in no way influenced by this increase. 
Archibald (4) states that this bird " eats a considerable quantity of corn, both in the fields and in farmyards, but it also destroys many insects, which form the chief food of the young, as well as the seeds of such plants as plantain, dock, wild vetch, chickweed, thistle, and knotgrass. Various green leaves, blackberries, and other wild fruit, are also included in its bill of fare."

Newstead (92) examined only four specimens. Florence (47) summarises the stomach contents of twenty-one specimens as follows : " 20 contained corn ; 1 , carpels of grass ; 1 , insect remains." It is important to point out that nineteen of these specimens were examined in January, 1910, one in March, and one in July.

I have post-mortem records of thirty adult and eight nestling birds, the former, as in all other cases, are fairly well spread over the twelve months of the year.

\section{Post-mortem Records.}

\begin{tabular}{|c|c|c|}
\hline ARTICLE OF DIET. & $\begin{array}{c}\text { Time: } \\
\text { occurred. }\end{array}$ & $\begin{array}{l}\text { Numiter } \\
\text { occurred. }\end{array}$ \\
\hline 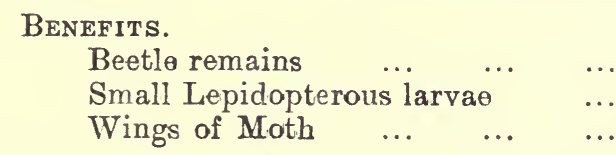 & $\begin{array}{r}13 \\
11 \\
1\end{array}$ & $\begin{array}{r}67 \\
72 \\
3\end{array}$ \\
\hline $\begin{array}{llll} & & & \\
& \ldots & \ldots & \ldots\end{array}$ & 15 & 212 \\
\hline 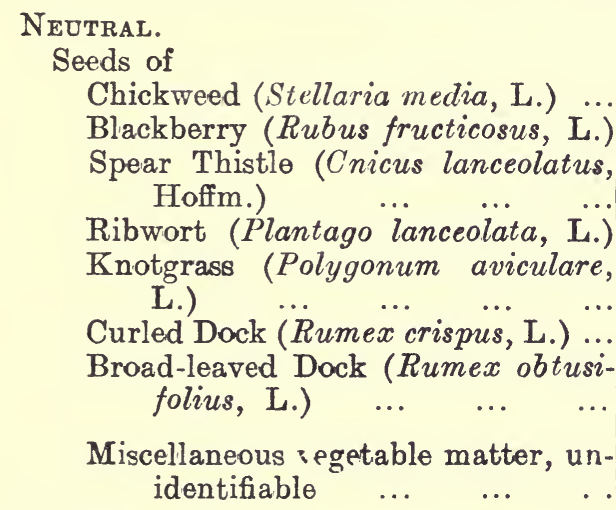 & $\begin{array}{r}3 \\
16 \\
10 \\
8 \\
12\end{array}$ & $\begin{array}{r}312 \\
19 \\
17 \\
482 \\
\\
308 \\
297 \\
339\end{array}$ \\
\hline
\end{tabular}




\section{Field Observations.}

All my observations in the field tend to confirm the opinion generally held, that this bird feeds mainly upon the seeds of weeds.

\section{Food of Nestlings.}

The stomach contents of the eight nestling birds consisted entirely of animal matter, the bulk of the food being the larva of some small Lepidopterous moth and spiders.

\section{Conclusion.}

In districts where it has been allowed to increase it undoubtedly does a certain amount of harm, but these cases are few ; generally speaking, it may be regarded as a beneficial bird.

\section{STARLING.}

\section{Sturnus vulgaris, Linn.}

A very divided opinion exists with reference to this bird, and I cannot do better than quote the opinions of some of those who have paid attention to the nature of its food and habits.

Gilmour (54) who examined the stomach contents of one hundred and ninety birds, states as the result of his investigation, that this species "is a bird rather to be fostered than destroyed; he is a benefactor rather than a foe to the farmer. . . . the starling, as a perusal of the record of his food will show, comes out of the examination with flying colours, and must be regarded most certainly as a friend of the farmer."

During the intervening eighteen years there has undoubtedly been an enormous increase of these birds, due very largely, I believe, to the preservation that is afforded them in other countries (103).

French (50) writing of this bird in Victoria, Australia, states: "There can be no doubt about the starling being a most pernicious enemy to the fruit-grower and viticulturist in this State. The starlings are increasing a thousand times faster than their natural food, hence they must avail themselves of such as is obtainable. Once driven to this an appetite is acquired, and fruit diet being easily obtained, they will not seek any other, even if available. It is pleasing to note that the Shire Councils are offering a bonus for starlings' heads and eggs. . . Valuable insect-eating birds, such as kingfishers, diamond-birds, tree creepers, and tree swallows are being driven out of their nesting places in tree-hollows by swarms of starlings, and before long these insectivorous birds, useful to the farmer and orchardist, will be driven out of the State." 
Smith (105) writes: "I do not think the starling has altered his food. The great increase in their numbers makes it more noticeable when they attack corn (which they have done at times for many years back). They are so rumerous now that the mischief they do is very marked. Cherries and damsons are the fruits they attack most. I believe the mild winters are responsible for the great increase in their numbers. They do a great amount of good as well as mischief, but the number should be kept within bounds."

Hooper (68) regards it as increasing in numbers, as also its taste for fruit.

Newstead (92) examined sixteen specimens, in addition to which, however, he gave the results of some highly important field observations.

Florence (47) enumerates the stomach contents of twenty-eight specimens, which are summarised as follows: " 8 contained insects of injurious groups; 5, beneficial group; 6, indifferent group; 17 , larvae; 4, spiders; 4, snails; 1 , centipede; 1 , earwig; 14, grain; 10 , seeds, etc., of weeds ; 8 , grass."

From January to June, 1911, I examined one hundred and forty-six birds, shot in the vicinity of Birmingham (32). The conclusions arrived at were summarised as follows: "the food of these birds during the first six months of the year was distinctly of an insectivorous character in the vicinity of the City of Birmingham, and that during those months the evidence from the food generally would lead us to place this species amongst those birds beneficial to the agriculturist and horticulturist, but a similar record extending over the same period taken in an agricultural district would, in all probability, reveal the starling as a destroyer of newly-sown grain, and extended over the summer months, would show that it inflicts considerable losses upon fruit-growers." The opinion then expressed has been fully borne out by work done in the latter part of 1911 and during 1912, when one hundred and eighty-two adult birds were examined and ninety-four nestlings. To these results I shall refer later.

Kelso (78) records the damage to corn.

Hammond (60) examined the stomach contents of two hundred and thirty-nine birds, and his conclusions are summarised as follows:-

"1. The starling is very beneficial during the late spring, summer and early winter months, eating many harmful insects, although a number of beneficial ones are also destroyed.

"2. During the autumn, and to a less extent in the spring, much harm is done by the consumption of seed corn (particularly wheat); many harmful insects, however, are also destroyed during this period." 
I have scheduled below the results of the examination of the two series of birds examined by myself.

\section{Post-mortem Records.}

1. 146 Birds from the vicinity of Birmingham, January to June.

\begin{tabular}{|c|c|c|}
\hline ARTICLE OF DIET. & $\begin{array}{c}\text { Times } \\
\text { occurred. }\end{array}$ & $\begin{array}{l}\text { Number } \\
\text { occurred. }\end{array}$ \\
\hline 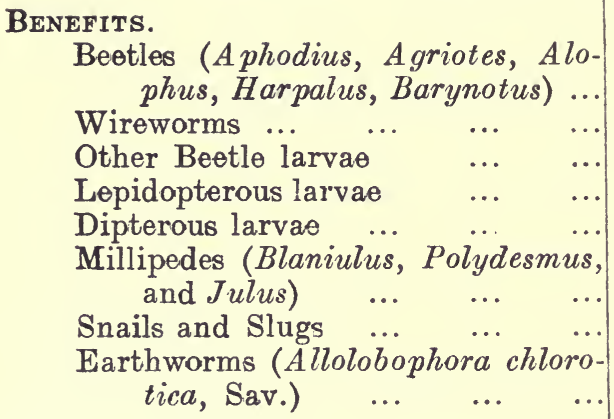 & $\begin{array}{r}123 \\
9 \\
97 \\
54 \\
21 \\
\\
41 \\
18 \\
\end{array}$ & $\begin{array}{r}633 \\
44 \\
418 \\
230 \\
140 \\
\\
64 \\
61 \\
\\
17\end{array}$ \\
\hline $\begin{array}{l}\text { InJuRIES. } \\
\text { Wheat }\end{array}$ & 12 & 83 \\
\hline 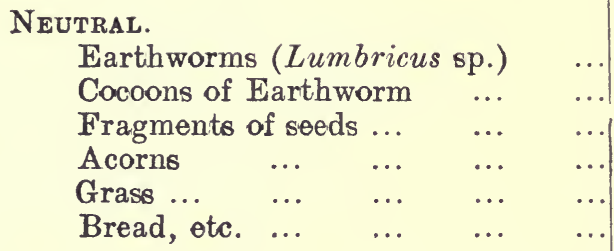 & $\begin{array}{r}2 \\
2 \\
22 \\
3 \\
39 \\
40\end{array}$ & $\begin{array}{l}7 \\
9 \\
5\end{array}$ \\
\hline
\end{tabular}

2. 182 Birds from Agricultural Districts, July to June.

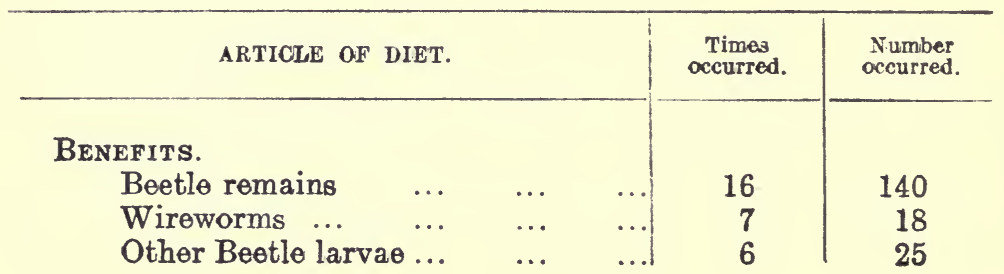




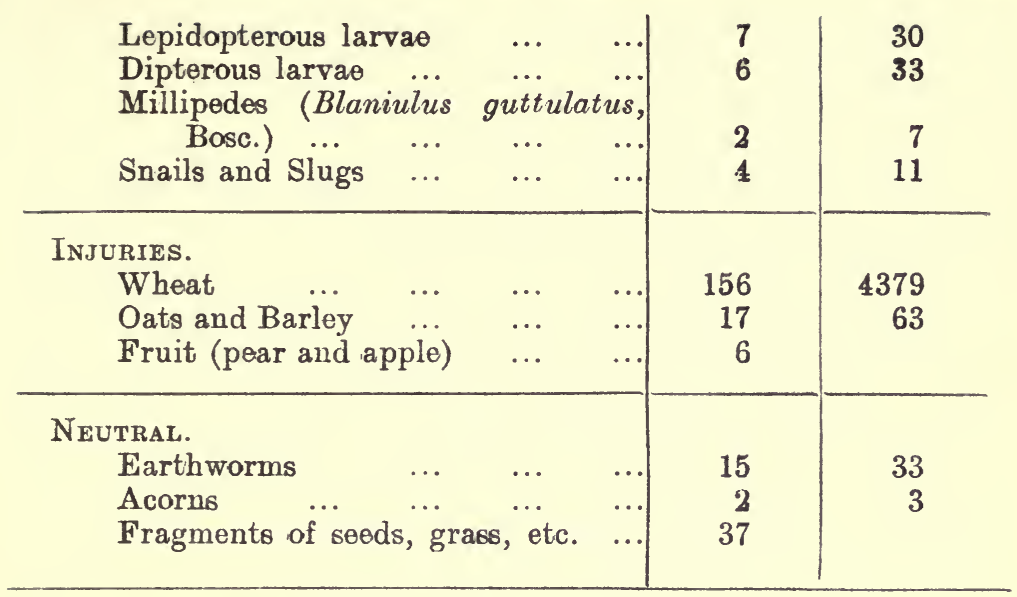

\section{Field Observations.}

I have frequently observed this bird eating slugs and the larvae of Crane Flies, on the other hand I have seen it do considerable damage to newly-sown wheat. In this connection I would refer to the observation of a correspondent, Mr. R. C. Thomas, of Bloxwich, who, in November last, forwarded a bird to me which contained : 37 grains of wheat and many bits of grains, remains of three earthworms, remains of one beetle, and a little grit. $\mathrm{He}$ writes: "The field of wheat from which the bird was shot, has been visited by great numbers of starlings, and I think I shall be well within the mark in estimating the flock at times, at 100,000 units; now, if each bird took 37 grains in one day, they would practically take the seed sown on 2 acres of land. I am quite sure if they were allowed, they would soon ruin the field of wheat in question, and I am afraid they have done a considerable amount of damage, notwithstanding care exercised to keep them away."

Another correspondent, writing from North Wales, writes: "What is the best means of getting rid of a plague of starlings? Perhaps you can hardly believe it, but thousands have come very suddenly to roost in my shrubbery, not only disfiguring the shrubs (some being valuable ones), but actually breaking large branches by their weight."

\section{Food of Nestlings.}

The food contents of the stomachs of ninety-four nestling birds has recently been set forth (34), as also some observations on the food brought to the nest by the parent birds. As these records are of importance, they may be conveniently repeated here. 
On May 11th, 12th, 18th, and 26th, careful notes were made at different periods of the day of the nature of the food, and these are given below.

May 11th, 10.30 to 11.5 a.m.-Fourteen visits were made to the nest, food being brought on each occasion. This consisted of 5 slugs (3 Arion hortensis, Fér., and 1 Agriolimax agrestis, Linn.); 3 earthworms ; 3 wireworms ; 2 larvae of the Great Yellow Underwing Moth (Triphaena pronuba, Linn.); a number of small beetles, too small to be identified, 3 larvae of Crane Fly ; 2 pieces of bread.

May 12th, 10.15 to 11.15 a.m.-Thirty-two visits were made to the nest by the parent birds, and food was brought on thirtyone occasions. The following were identified:-18 larvae of the Great Yellow Underwing Moth (Triphaena pronuba, Linn.), 16 slugs (12 Arion hortensis, Fér., and 4 Agriolimax agrestis, Linn.); 8 small earthworms; several small beetles; 2 spiders; 3 wireworms; a number of Dipterous larvae.

May 18th.-At various times of the day fifty-two visits were observed, at each of which food was brought to the nest. The following were identified:-4 weevils (Barynotus obscurus, Fabr.); 3 wireworms; 15 larvae of the Great Yellow Underwing Moth; many small Geometrid larvae; 4 larvae of Crane Fly; 4 earthworms; 10 slugs (Arion hortensis, Fér.); 2 pieces of meat.

May 26th.-Forty-eight visits were observed. The following food was identified:-6 large Noctuid larvae; 8 larvae of Crane Fly; 4 wireworms; number of small beetles; 11 slugs (8 Arion hortensis, Fér., and 3 Agriolimax agrestis, Linn.) ; 3 earthworms ; 2 spiders; bread and kitchen garbage on 5 occasions.

Thus on one hundred and forty-six visits the following food was conveyed to the nest:-61 insect larvae; a large number of small beetles; 18 earthworms; 42 slugs; 4 spiders; and various Dipterous larvae, bread, etc. The whole fairly represents the food eollected during the period of half a day.

The post-mortem records of ninety-four examples are as follows:

May 20th.-Twenty specimens received. The food contents identified were:-8 larvae of the Great Yellow Underwing Moth; 8 larvae of the Winter Moth; 9 small Lepidopterous larvae; parts of 5 wireworms; wing cases and legs of 3 beetles; few small Dipterous larvae; 3 spiders; remains of slugs; few pieces of earthworms; bread in all cases.

May 23rd.-Fourteen specimens received. The food contents identified were :-5 larvae of the Great Yellow Underwing Moth; 8 small Lepidopterous larvae; many small Dipterous larvae; remains of 9 slugs (Arion hortensis, Fér.); few pieces of earthworms; bread and vegetable matter present in 12 cases. 
May 25th.-Sixteen specimens received. The food contents identified were:-8 larvae of Great Yellow Underwing Moth; 9 larvae of the Winter Moth; 5 wireworms; 7 wing cases of weevils Barynotus obscurus, Fabr.); few Fungus Gnats; 3 spiders; 2 centipedes; remains of 5 slugs; few pieces of earthworms; bread, meat, and vegetable matter present in 7 cases.

May 28th.-Twenty-two specimens received. The food contents identified were:-5 larvae of the Great Yellow Underwing Moth; 7 small Lepidopterous larvae; 8 wireworms; 11 wing cases of weevils (Barynotus obscurus, Fabr.); various small Dipterous flies; 2 spiders; 1 centipede; remains of 11 slugs (Arion hortensis, Fér.); 7 partly digested earthworms (Allolobophora chlorotica, Sav.); bread, meat, and vegetable matter present in 15 cases.

May 29th.-Twenty-four specimens received. The food contents identified were :-6 larvae of the Great Yellow Underwing Moth; 10 larvae of the Winter Moth; 9 wireworms; wing cases, legs and other remains of 23 beetles; 3 spiders; 1 slug (Arion hortensis, Fér.); 9 earthworms (Allolobophora chlorotica, Sav.); bread, meat and vegetable matter present in 19 cases.

\section{Examination of Faeces.}

Large quantities of the encapsuled faeces of young starlings were collected and subjected to careful examination. The results obtained are of interest in that they confirm the observations made on the nature of the food brought to the nest by the parent birds.

The faeces collected and examined during the first ten days gave but poor results, and would seem to point to the fact that worms, slugs, and quite soft food formed the bulk of the food during that period. The following materials were identified:-5 wing cases of beetles; 8 pieces of wings of some Dipterous insect; 14 heads of Lepidopterous larvae; 1 remains of wireworm.

The faeces collected and examined later showed the following remains:-1 wing case of ground beetle (Pterostichus madidus, Fabr.); 19 legs of various small beetles; 1 wing case of ladybird beetle; 23 wing cases of weevils; 27 heads of Lepidopterous larvae; parts of 5 wireworms; half of centipede (Geophilus longicornis); fragments of plant remains; grit.

\section{Conclusion.}

As has long been contended by agriculturists, numerically this bird has increased enormously during the last ten or twelve years. This increase I believe to be largely due to migration and the protection afforded to wild birds in general. Considerably reduced in numbers, I believe the starling would regain the good name it has borne in the past, and prove a most useful bird to the farmer; at present it is far too numerous and a source of considerable loss. 


\section{JAY. \\ Garrulus glandarius, Linn.}

This handsome bird in most districts is becoming rarer and rarer, owing to the persecution of the gamekeeper.

Archibald (6) states that they consume large quantities of pheasant food, and also that they take the eggs of game and strip the pods of peas.

Smith (105) states: "In the neighbourhood of game preserves the jay sometimes does much damage to the apple crops by taking a bite out of any rosy-faced apple that looks tempting, spoiling very many, without consuming any great quantity. He is also a great nut-cracker, taking the point of the nut off as you would with a knife, inserting his beak, and opening the nut. He is very fond of green peas, and plums do not come amiss to him. Where fruit is grown he should be kept down."

Hooper (68) remarks that "when a fruit plantation is near a wood, the jay is apt to peck and disfigure apples; it takes nuts, is fond of green peas and plums, and is said to feed on ripe cherries. It eats the eggs of the blackbird and wood pigeon, and is useful in this way. Its food consists of acorns, beech-nuts, worms, snails, slugs, cockchafers, beetles, insect larvae, mice, eggs and young birds."

Newstead (92) examined twenty-three specimens, the stomach contents of which he summarises as follows: " 10 contained insects of the injurious group; 4, beneficial group; 4, indifferent group; 5 , wheat and oats ; 9 , acorns ; 2 , potato ; 2 , shells of birds' eggs; 1 , miscellaneous ; 1 , grass ; 2 , bones of mammal."

Of eighteen specimens examined, the stomach contents are scheduled below.

Post-mortem Records.

\begin{tabular}{|c|c|c|c|}
\hline ARTICLE OF DIET. & & $\begin{array}{c}\text { Times } \\
\text { occurred. }\end{array}$ & $\begin{array}{l}\text { Number } \\
\text { occurred. }\end{array}$ \\
\hline 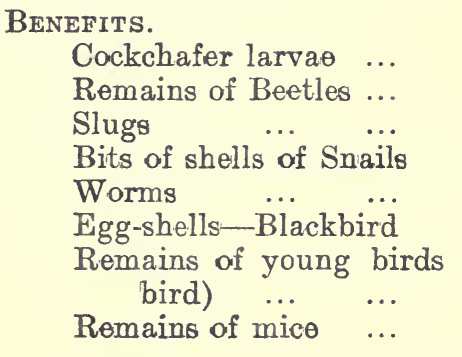 & $\begin{array}{cr}\ldots & \ldots \\
\ldots & \ldots \\
\ldots & \ldots \\
\ldots & \ldots \\
\ldots & \ldots \\
\ldots & \ldots \\
(? & \text { Black- } \\
\ldots & \cdots \\
\ldots & \cdots\end{array}$ & $\begin{array}{r}6 \\
7 \\
3 \\
3 \\
11 \\
5 \\
\\
2 \\
2\end{array}$ & $\begin{array}{l}22 \\
38 \\
11\end{array}$ \\
\hline
\end{tabular}




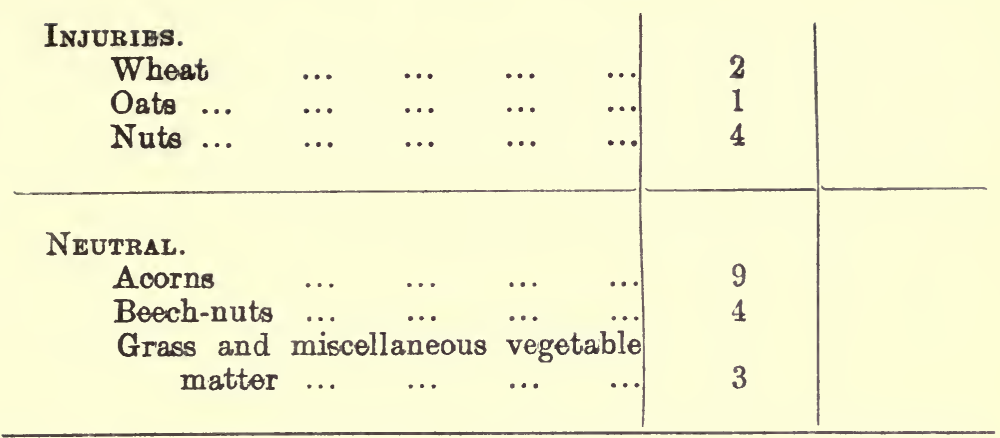

\section{Field Observations.}

The only injury I have personally seen this bird commit was to apples, many of which had a piece bitten out.

\section{Conclusion.}

I regard the Jay as an almost neutral factor. In some districts where more plentiful than elsewhere, it undoubtedly damages fruit, on the other hand it destroys blackbirds and mice, and consumes a large quantity of insect larvae and slugs.

\section{MAGPIE.}

\section{Pica rustica (Scopoli).}

To fix the economic status of this bird is a problem of some difficulty, for, whilst beneficial to a great extent to the fruit-grower and agriculturist, it is very destructive to game. The opinions given below and the schedule of the stomach contents of twentyfour birds, will in some measure, help to overcome this difficulty I hope.

Archibald (6) states: "It destroys quantities of eggs and young birds of all kinds, and, like the rest of its family, will eat almost anything. To the farmer and fruit-grower it renders considerable service by destroying insects, rats, mice, and the eggs of wood-pigeons and many fruit-eating birds."

Hooper (68) remarks that it eats cherries, but is valuable in destroying the wood-pigeon.

Theobald (109) refers to this bird as affording "a most difficult problem." "It is an arrant thief," he states, "it will take young chicks and eggs, it strips rows of peas, and will even attack young and sickly stock." 
Newstead (92) examined only eight specimens: the stomach contents he summarises as follows: " 7 contained insècts of the injurious group ; 4 , beneficial group; 4 , indifferent group; 1 , wheat and oats; 1, acorns; 1, a holly berry; 1, a field vole; 2, pellets of sheep's wool." Florence (47) examined a single specimen only.

\section{Post-mortem Records.}

\begin{tabular}{|c|c|c|}
\hline ARTICLE OF DIET. & $\begin{array}{c}\text { Times } \\
\text { occurred. }\end{array}$ & $\begin{array}{l}\text { Number } \\
\text { occurred. }\end{array}$ \\
\hline 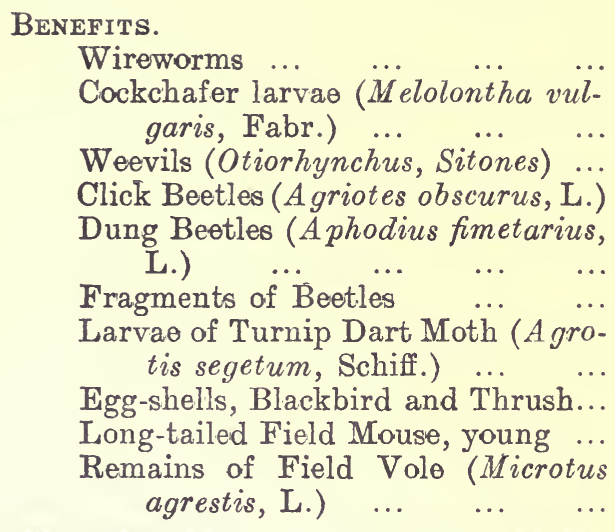 & $\begin{array}{r}7 \\
9 \\
12 \\
3 \\
\\
2 \\
14 \\
\\
6 \\
4 \\
1 \\
1\end{array}$ & $\begin{array}{c}43 \\
\\
41 \\
99 \\
26 \\
\\
9 \\
180 ? \\
27\end{array}$ \\
\hline $\begin{array}{l}\text { INJURIES. } \\
\text { Egg-shells, Pheasant } \\
\text { Remains of chicken }\end{array}$ & $\begin{array}{l}1 \\
1\end{array}$ & \\
\hline $\begin{array}{l}\text { Neutral. } \\
\begin{array}{llll}\text { Acorns } & & & \\
\text { Holly berries } & \ldots & \ldots & \ldots \\
\text { Miscellaneous vegetable matter } & \ldots\end{array}\end{array}$ & $\begin{array}{l}3 \\
1 \\
5\end{array}$ & 4 \\
\hline
\end{tabular}

\section{Field Observations.}

I have quite a number of records of this species destroying young birds-blackbirds, thrushes and wood-pigeons. The number of eggs of these birds that a pair of magpies will destroy in a season must be considerable. On more than one occasion I have disturbed them when feeding upon the field vole, but only once upon young game. The damage they do to young game and the eggs of game birds, is, I think, exaggerated. 


\section{Conclusion.}

Apart from the question of game, the mapgie is a bird that is beneficial to the agriculturist, feeding, as it does, largely upon soil larvae and beetles, whilst it destroys field mice, voles, blackbirds and wood-pigeons.

\section{JACKDAW.}

Corvus monedula, Linn.

Curious as it may seem we have very little detailed information as to the exact nature of the food of this interesting bird.

The following extracts from a series of reports on this bird will illustrate the strange diversity of opinion.

i. "From the farmers' standpoint this is decidedly a beneficial bird, and I should not recommend its destruction at all."

ii. "Far too many of these birds, which do considerable damage to the eggs of game birds."

iii. "Certainly injurious to orchards and game eggs, should welcome a considerable decrease in their numbers."

iv. "Destructive to peas, grain crops and far too numerous."

Archibald (6) states: "Jackdaws eat a quantity of snails and insects, but they are very mischievous, devouring eggs, young birds, corn and fruit."

Hooper (68) remarks that it "does little injury to fruit, is partial to cherries, destroys many insects, including wireworms."

Theobald (109) writes: " is a great wireworm and insect destroyer, and if it does a little injury to cherries and other fruit in dry seasons, and takes a few eggs and now and then fowl's food, it nevertheless must be looked upon as beneficial, as far as evidence goes at present."

Newstead (92) examined the stomach contents of eleven specimens, his summary is as follows: " 7 contained insects of the injurious group; 1 , beneficial group ; 4 , indifferent group; 7, wheat and oat glumes; 1 , potato ; 1 , molluse ; 2 , sheep's wool." 
Post-mortem Records.

\begin{tabular}{|c|c|c|}
\hline ARTICLE OF DIET. & $\begin{array}{c}\text { Timies } \\
\text { occurred. }\end{array}$ & $\begin{array}{l}\text { Number } \\
\text { occurred. }\end{array}$ \\
\hline 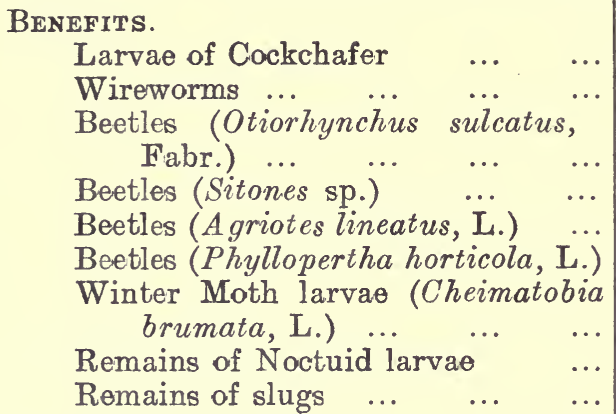 & $\begin{array}{r}3 \\
18 \\
\\
7 \\
3 \\
8 \\
4 \\
\\
3 \\
13 \\
3\end{array}$ & $\begin{array}{r}11 \\
157 \\
62 \\
17 \\
73 \\
36 \\
\\
10 \\
67 \\
14 ?\end{array}$ \\
\hline $\begin{array}{l}\text { INJURIEs. } \\
\qquad \begin{array}{llll}\text { Wheat } \quad \ldots & \ldots & \ldots & \ldots \\
\text { Potatoes (young) } \ldots & \ldots & \ldots \\
\text { Pheasant or fowl food } & \ldots & \ldots \\
\text { Beetles (Carabus violaceus, L., and } \\
\text { Pterostichus madidus, Fabr.)... }\end{array}\end{array}$ & $\begin{array}{l}4 \\
2 \\
2 \\
2\end{array}$ & $\begin{array}{r}38 \\
6 \\
5\end{array}$ \\
\hline $\begin{array}{l}\text { Neurral. } \\
\text { Ball of sheep's wool ... } \\
\begin{array}{l}\text { Miscellaneous vegetable matter, not } \\
\text { identifiable } \quad . .\end{array} \quad \ldots \quad \ldots\end{array}$ & 1 & \\
\hline
\end{tabular}

\section{Field Observations.}

That the jackdaw is an inveterate thief, few will deny, but a long acquaintance with the habits of this bird does not justify me in describing it as an injurious species. Insect larvae, beetles, and slugs form a very large proportion of its food, and, although I have watched it carefully in the orchard, the only charge I have against it, is that in dry summers it devours ripe cherries, but these have usually been more than paid for by the number of larvae of the Winter Moth eaten earlier in the season.

I have been unable to obtain any nestlings, but have watched the parent birds during the breeding season carrying food to the nest, which consists almost entirely of insect larvae.

\section{Conclusion.}

Unless exceedingly numerous, the good the jackdaw does far outweighs any harm, and I think that frequently its destruction is quite unnecessary. 


\section{ROOK.}

\section{Corvus frugilegus, Linn.}

Few birds are better known than the rook, partly owing to the fact of its living in flocks, and also that it usually selects for its breeding places a situation close to human habitation.

In some localities it has undoubtedly rapidly increased during the last ten years; this is particularly so in Scotland, where it is said to destroy eggs on a large scale.

During the autumn months there is a large migration from the Continent on our east coast, and a return migration has been noted in the early spring.

The nest is usually built about the middle of March, but in some localities the birds have been observed building both earlier and later. Tall trees are usually selected, but sometimes firs, pollard-willows and even bushes have been chosen, and occasionally chimney-tops and church spires.

The nest consists of twigs and turf, lined with roots and straw. Here the three to five bluish-green eggs, blotched and streaked with olive-brown, are laid.

Breeding commences when the birds are nearly two years old.

Excepting the house-sparrow, no other wild bird has had so much attention devoted to its economic status as has the rook.

Gilmour's (54) well-known investigation, in which he made post-mortems of three hundred and fifty-five birds, showed that:-

Cereal grain and husk occurred 290 times or 58 per cent.

Insects, grubs, etc.

Miscellaneous

Roots

Leaves

Flowers

Fruits and seeds, not cereals

,",

116 ,

60,

36,

0 ,

0 ,

0,
23,

12,

7,

0 ,

0 , ,

0,

"These figures show that at least three-fourths of rook-food (81 per cent.) is cereal grain and husk, with insect and grub; also that grain and husk are at least twice as frequently met with as insects and grubs."

"Taken altogether," he concludes, "the rook has almost no claim to agricultural regard." 
Newstead (92) only examined fourteen specimens, nine of which were shot on one day in May.

Florence (47) examined one hundred and sixty-two, and Hammond (60) gives the results of the examination of a dozen specimens.

Thring (31) in 1908 made post-mortems of one hundred and forty-one, and in 1907 and '08 I examined 58, and six hundred and thirty-one in 1909, and since then a further 32 , so that we now have the records of 1,393 stomach contents.

As I have elsewhere mentioned (31) it has generally been supposed that the food of the rook consists very largely of beetles, insect larvae, and earthworms. A well-known ornithologist, the Rev. F. O. Morris, presented the following calculation before the "Wild Birds' Protection Committee of the House of Commons of 1873 " : "A rook," he states, " requires at least one pound of food in a week, and of this nine-tenths is insect and worms. A rookery of 10,000 rooks will consume in one year 209 tons of worms, insects, and their larvae." Other writers have made similar statements, but without any convincing evidence, so far as I am aware.

Of the 631 specimens I opened, 70 per cent. of their food consisted of grain, 15 per cent. of seed, fruits, roots, and miscellaneous vegetable matter; 4 per cent. of wireworms, 4 per cent. of other insects (mostly injurious), 1 per cent. millipedes, 2 per cent. earthworms, 4 per cent. miscellaneous food. Adding these to the 141 rooks recorded by Mr. Douglas T. Thring, and the fiftyeight specimens previously dissected by myself, the results may be tabulated as follows:-

\begin{tabular}{|c|c|c|c|c|}
\hline No. of Rooks... & 631 & 58 & 141 & $\begin{array}{l}\text { Total. } \\
830\end{array}$ \\
\hline Grain ... ... & 70 & 65 & & \\
\hline $\begin{array}{l}\text { Seeds, fruits, roots, and } \\
\text { miscellaneous vegetable }\end{array}$ & & & 53 & $71 \%$ \\
\hline $\begin{array}{cccc}\text { matter } & \ldots & \ldots & \ldots\end{array}$ & 15 & 10 & & \\
\hline Wireworms ... & 4 & 6 & & \\
\hline Other insects & 4 & 6 & 30 & $15 \%$ \\
\hline Millipedes $\quad .$. & 1 & 1 & & \\
\hline Earthworms $\ldots \quad \ldots \quad \ldots$ & 2 & $1:$ & 17 & $10.5 \%$ \\
\hline 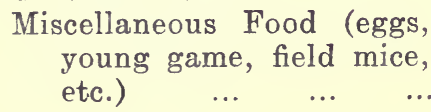 & 4 & 6 & - & $\%$ \\
\hline
\end{tabular}

The following diagram illustrates at a glance, the monthly consumption of food, animal and vegetable. 


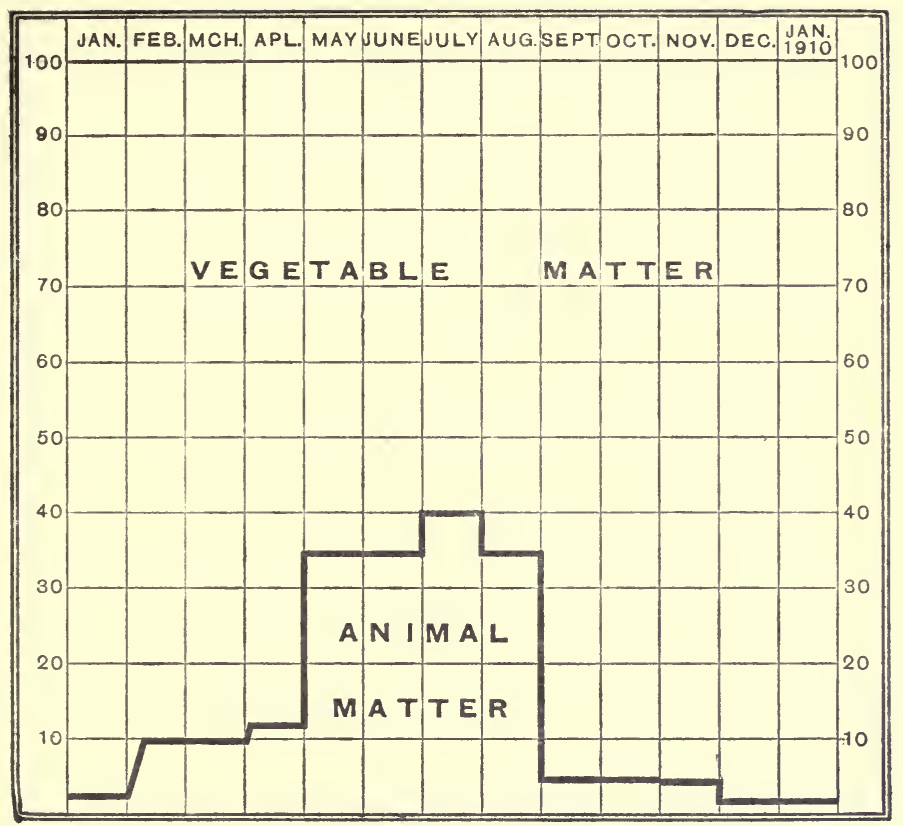

\section{Post-mortem Records.}

The following summary shows the stomach contents of six hundred and sixty-three birds, eighty-one of which were empty.

ARTICLE OF DIET.

\section{Benefits.}

Earwig (Forficula auricularia, L.)

Plant Bug (Pentatoma sp.)

Wireworm

\section{... $\quad \ldots$}

$\ldots$

$\cdots$

…

Click Beetles (Agriotes lineatus, L.)
Green Rose Chafer (Cetonia aurata, L.)

Black Vine Weevil (Otiorhynchus sulcatus, Fabr.)

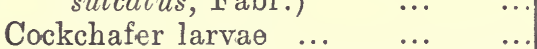

May Bug (Phyllopertha horticola,

L.) $\quad \ldots \quad$... $\quad \ldots \quad \ldots$

June Bug (Rhizotrogus solstitialis,

L.)
Times occurred.

Number occurred. 
Remains of Beetles ...

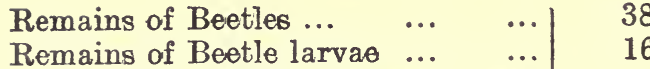

Larvae of Lepidoptera (mostly Noc-

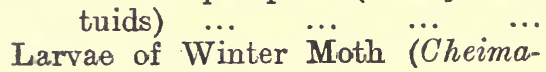
tobia brumata, L.)

Larvae of Turnip Dart Moth (Agrotis segetum, Schiff.) ... ...

Leather Jackets $\quad \ldots \quad \ldots \quad \ldots$

Blow Fly $\quad \ldots \quad \ldots \quad \ldots . \quad \ldots$

Wasps

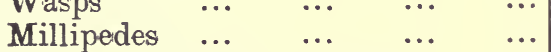

Land shell (Helix hispida)...

Small Birds ...

Blackbirds

Egg shells of Blackbird

Long-tailed Field-mouse

Intestine of Rabbit...

\section{INJURIES.}

$\begin{array}{lllll}\text { Grain } & \ldots & \ldots & \ldots & \ldots \\ \text { Broad beans } \ldots & \ldots & \ldots & \ldots\end{array}$

Grass and other roots $\quad \ldots \quad \ldots$

Black Ground Beetle (Pterostichus madidus, Fabr.) $\quad \ldots \quad$...

$\begin{array}{lllll}\text { Bees } \ldots & \ldots & \ldots & \ldots & \ldots \\ \text { Centipede } & \ldots & \ldots & \ldots & \ldots\end{array}$

$\begin{array}{llll}\text { Pheasant eggs } & \ldots & \ldots & \ldots\end{array}$

Pheasant food $\quad \ldots \quad \ldots$...

Red Currant

Gooseberries

Neutral.

Acorns

Seeds of

Charlock (Sinaspis arvensis, L.) ...

Dock (Rumex crispus, L.) ... ...

Knotgrass (Polygonum aviculare, L.) L.)

Goosegrass (Galium verum, L.)

Dung Beetles

Other Beetles

Earthworms ... $\quad \ldots \quad \ldots$

$\begin{array}{lll}\cdots & \cdots & \cdots\end{array}$

Bread, potatoes, etc. $\quad \ldots . \quad \cdots$

Miscellaneous vegetable matter

2

\section{8}




\section{Conclusion.}

There is ample evidence to show that with the present large number of rooks, a grain diet is preferred.

So far as the evidence of this inquiry shows, the rook is not a particularly beneficial bird to the agriculturist, although its usefulness might be considerably increased were it less numerous.

\section{SKYLARK.}

\section{Alauda arvensis, Linn.}

The results obtained from an investigation of forty post-mortems of adults and nine of nestlings agree fairly closely with those obtained by Hammond (60), indeed, the only difference is the method of tabulation, thus I regard Collembola as distinctly injurious, whereas he places them under the heading "neutral," and seeds of weeds under "benefits."

Archibald (4) states: "The food of the skylark is composed to some extent of farm produce, but for this it makes amends by eating many destructive insects, including the wireworm, as well as the seeds of such pernicious weeds as charlock, knotgrass, and chickweed. Seed corn, especially autumn-sown wheat, both before and after sprouting, possesses great attractions for it, but it is only in exceptional cases that the crop is materially injured in eonsequence."

Hammond (60) sums up as follows: "The bulk of the food consists of weed seeds; this is eked out in the summer months by insects, and in the winter by pieces of leaf, for the most part of crops. . . the damage to leys and wheat is done for the most part by the migratory birds; but the damage to 'small seeds' is probably done by the birds breeding here. The conclusion reached is that, on the whole, the lark is beneficial; but, owing to the injuries done at certain times of the year, there is no reason why it should be specially protected, although its wholesale slaughter is to be deprecated."

\section{Post-mortem Records.}

Forty stomachs were examined, the specimens being obtained during each month of the year. The materials found may be suminarised as follows:- 


\begin{tabular}{|c|c|c|}
\hline ARTICLE OF DIET. & $\begin{array}{c}\text { Times } \\
\text { occurred. }\end{array}$ & $\begin{array}{l}\text { Number } \\
\text { occurred. }\end{array}$ \\
\hline 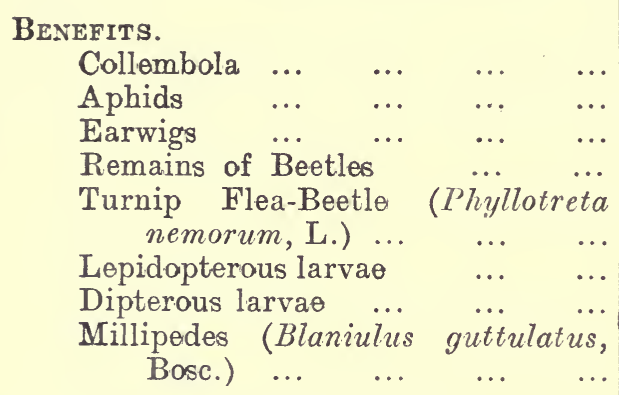 & $\begin{array}{r}1 \\
3 \\
2 \\
19\end{array}$ & $\begin{array}{r}11 \\
89 \\
3 \\
123\end{array}$ \\
\hline 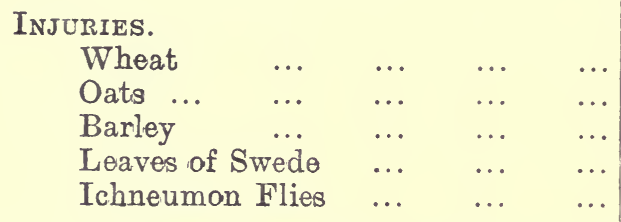 & $\begin{array}{l}7 \\
2 \\
1 \\
2 \\
2\end{array}$ & $\begin{array}{r}64 \\
5 \\
3 \\
\\
7\end{array}$ \\
\hline $\begin{array}{l}\text { Neutral. } \\
\text { Spiders } \quad \ldots \quad \ldots \\
\text { Seeds of } \\
\text { Charlock (Sinaspis arvensis, L.) }\end{array}$ & $\begin{array}{r}1 \\
15 \\
14 \\
4 \\
9 \\
\\
6 \\
9 \\
3 \\
4 \\
6\end{array}$ & $\begin{array}{r}3 \\
\\
300 \\
322 \\
31 \\
141 \\
\\
70 \\
211 \\
39 \\
15\end{array}$ \\
\hline
\end{tabular}

\section{Field Observations.}

The only time I have observed this bird doing any damage is during hard weather when food has been scarce. In some districts the farmers say there are too many larks, and that they require lessening in number. 


\section{Food of Nestlings.}

The food of the nine nestlings consisted entirely of the remains of insects, amongst these a small Jepidopterous larva, aphids and beetle remains were prominent. In two cases wireworms were present.

\section{Conclusion.}

The lark, generally speaking, does more good than harm. The migratory birds arriving in the autumn should to some extent be destroyed.

\section{BARN OWL.}

\section{Strix flammea, Linn.}

The habits of this much maligned bird will bear the strictest investigation; indeed, the more we know of the details the more manifest is its beneficial character shown to be. Few who have studied it, have anything but good to record, thus Archibald (3) writes: "It subsists mainly on mice and shrews, including tho destructive little vole, or, as it is more commonly called, the short-tailed field mouse. . . . The quantity of these small devastating animals thus consumed is, indeed, enormous; and, even if the barn-owl were mischievous in other ways-which it is not-its very great services in keeping down an enemy, capable of such wholesale destruction, should cause it to be rigidly protected throughout the year.

"Its diet is frequently varied with rats, moles, and water-rats, whilst bats, large insects, and even fish are also sought for, . . . Small birds are occasionally taken, but not often; thus, in the examination of 706 pellets, Dr. Altum found the remains of nineteen sparrows, one greenfinch, and two swifts."

Smith (105) states: "I must say a good word for our friend the owl. I am sorry to say he will soon be a rare bird unless something can be done to save him. There is a general idea among keepers that the owl is a destroyer of game, but I do not think he deserves that character; he lives chiefly on mice, rats, beetles and moles. I once gave a tame owl eleven mice; the last one certainly stuck out of his mouth for some time, but by jumping vigorously, with his head pointing straight upward, the bird succeeded it getting it down!"”

Hooper (68) says: "The Barn Owl is a most valuable mouse killer, nine-tenths of its food appears to consist of mice; the number 
it catches is wonderful. In 1,124 pellets examined by Mr. L. E. Adams, remains of 2,397 mice and rats, and 97 sparrows were found."

Newstead (92) examined twelve specimens, and summarises the stomach contents as follows: " 1 contained insects of the injurious group ; 1 , beneficial group; 2 , indifferent group ; 5 , voles ; 2 , mice ; 2 , shrews ; 1 , bats ; 3 , birds.'

Adams (1) examined eleven hundred and twenty-four pellets of this species, and records the following animals :-

\begin{tabular}{|c|c|c|c|c|c|c|c|}
\hline \multicolumn{7}{|c|}{ ARTICLE OF DIET. } & \multirow{2}{*}{$\begin{array}{c}\text { Number } \\
\text { occurred. } \\
5\end{array}$} \\
\hline Mole ... & $\ldots$ & ... & ... & $\cdots$ & $\ldots$ & $\ldots$ & \\
\hline Common Shrew & $\ldots$ & $\ldots$ & $\ldots$ & $\ldots$ & $\ldots$ & $\ldots$ & 413 \\
\hline Lesser Shrew & $\ldots$ & $\ldots$ & $\ldots$ & $\ldots$ & $\ldots$ & $\ldots$ & 28 \\
\hline Water Shrew & $\ldots$ & $\ldots$ & $\ldots$ & $\ldots$ & $\ldots$ & $\ldots$ & 28 \\
\hline Long-tailed Field & Mouse & $\ldots$ & $\ldots$ & $\ldots$ & $\ldots$ & $\ldots$ & 697 \\
\hline House Mouse ... & $\ldots$ & $\ldots$ & $\ldots$ & .. & .. & & 29 \\
\hline Brown Rat ... & . & $\ldots$ & $\ldots$ & $\ldots$ & $\ldots$ & $\ldots$ & 205 \\
\hline Short-tailed Field & Mouse & (Field & Vole) & $\ldots$ & $\ldots$ & $\ldots$ & 861 \\
\hline Bank Vole ... & $\ldots$ & $\ldots$ & $\ldots$ & $\ldots$ & $\ldots$ & $\ldots$ & 136 \\
\hline Water Vole ... & $\ldots$ & $\ldots$ & $\ldots$ & $\ldots$ & $\ldots$ & $\ldots$ & 10 \\
\hline Rabbit $\quad \ldots$ & $\ldots$ & $\ldots$ & $\ldots$ & $\ldots$ & $\ldots$ & $\ldots$ & 2 \\
\hline Frog $\ldots$ & $\ldots$ & $\ldots$ & $\ldots$ & $\ldots$ & $\ldots$ & $\ldots$ & 9 \\
\hline Sparrow & $\ldots$ & $\ldots$ & $\ldots$ & $\ldots$ & $\ldots$ & $\ldots$ & 97 \\
\hline Thrush or Blackbi & & $\ldots$ & $\ldots$ & $\ldots$ & $\ldots$ & $\ldots$ & 23 \\
\hline Starling $\quad \ldots$ & $\ldots$ & $\ldots$ & $\ldots$ & $\ldots$ & $\ldots$ & $\ldots$ & 4 \\
\hline Other Small Birds & 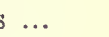 & $\ldots$ & $\ldots$ & $\ldots$ & $\ldots$ & $\ldots$ & 54 \\
\hline Squirrel $\quad \ldots$ & $\ldots$ & $\ldots$ & $\ldots$ & $\ldots$ & $\ldots$ & $\ldots$ & 1 \\
\hline Beetles & $\ldots$ & $\ldots$ & $\ldots$ & $\ldots$ & $\ldots$ & $\ldots$ & 3 \\
\hline Total No. of Anim & nals & $\ldots$ & $\ldots$ & $\ldots$ & $\ldots$ & $\ldots$ & 2605 \\
\hline
\end{tabular}

An examination of the stomach contents of seven specimens $I$ examined is given below.

Post-mortem Records.

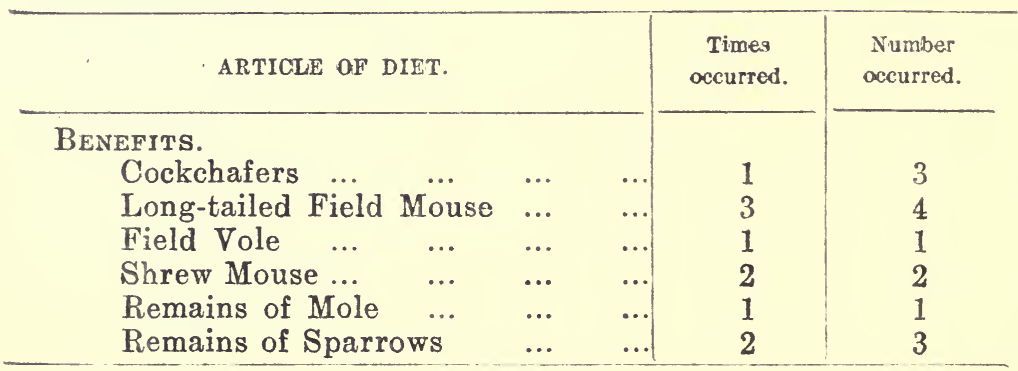


Examination of 83 Pellets.

\begin{tabular}{|c|c|c|c|c|c|c|c|c|}
\hline \multicolumn{8}{|c|}{ ARTLCLE OF DIET. } & \multirow{2}{*}{$\begin{array}{r}\begin{array}{r}\text { Number } \\
\text { occurred. }\end{array} \\
1\end{array}$} \\
\hline Mole ... & ... & $\ldots$ & $\ldots$ & $\ldots$ & $\ldots$ & $\ldots$ & ... & \\
\hline Field Vole & $\ldots$ & $\ldots$ & ... & $\ldots$ & $\ldots$ & $\ldots$ & $\ldots$ & 16 \\
\hline Bank Vole & $\ldots$ & $\ldots$ & $\ldots$ & $\ldots$ & $\ldots$ & $\ldots$ & ... & 17 \\
\hline \multirow{2}{*}{\multicolumn{3}{|c|}{$\begin{array}{l}\text { Common Shrew Mouse } \\
\text { Long-tailed Field Mouse }\end{array}$}} & $\ldots$ & $\ldots$ & $\ldots$ & $\ldots$ & $\ldots$ & 56 \\
\hline & & & $\ldots$ & $\ldots$ & $\ldots$ & $\ldots$ & ... & 29 \\
\hline \multicolumn{2}{|c|}{ House Mouse } & $\ldots$ & $\ldots$ & $\ldots$ & $\ldots$ & $\ldots$ & $\ldots$ & 3 \\
\hline Blackbird & $\ldots$ & $\ldots$ & $\ldots$ & $\ldots$ & $\ldots$ & $\ldots$ & ... & 2 \\
\hline \multirow{2}{*}{$\begin{array}{l}\text { Thrush } \\
\text { Starling }\end{array}$} & $\ldots$ & ... & $\ldots$ & $\ldots$ & $\ldots$ & $\ldots$ & $\ldots$ & 2 \\
\hline & $\ldots$ & $\ldots$ & $\ldots$ & $\ldots$ & $\ldots$ & $\ldots$ & $\ldots$ & 1 \\
\hline \multicolumn{2}{|c|}{ House Sparrow } & $\ldots$ & $\ldots$ & $\ldots$ & $\ldots$ & $\ldots$ & $\ldots$ & 33 \\
\hline \multicolumn{3}{|c|}{ Dung Beetles, remains } & $\ldots$ & $\ldots$ & $\ldots$ & $\ldots$ & $\ldots$ & 7 \\
\hline \multicolumn{3}{|c|}{ Cockchafer, remains } & $\ldots$ & $\ldots$ & $\ldots$ & $\ldots$ & ... & 16 \\
\hline
\end{tabular}

\section{Conclusion.}

A most valuable bird to the agriculturist, and perfectly harmless otherwise. Should certainly be protected.

\section{BROWN OWL.}

\section{Syrnium aluco (Linn.).}

In spite of years of persecution the Brown or Tawny Owl is still fairly plentiful.

Writing at some length on the habits and food of this bird, Archibald (3) says: "With regard to the accusation that the brown owl habitually destroys game-birds, a small amount of reflection makes the practical impossibility of such a proceeding manifest, for the simple reason that young pheasants and partridges are safely hidden beneath their mother's wing long before the tawny owl considers it fit to stir abroad. Even the most uncompromising preserver could hardly consider its fancy for the young of ground game a very great sin, whilst this taste is in itself an additional claim upon the sympathies of the agricultural world.

"A very large portion of its food consists of rats and mice, and it ranks with the barn owl and kestrel as one of the farmer's best friends. Water-rats, moles, and young rabbits frequently form part of its diet, and more rarely leverets, squirrels, small birds and fish; whilst beetles, including the destructive cockchafer, are sometimes devoured by it in great numbers."

Newstead (92) examined ten specimens, and summarises the stomach contents as follows: " 1 contained insects of the injurious 
group; 1, indifferent group; 1 , beneficial group; 1, worms; 1 , slugs; 3 , grass ; 3 , voles ; 2 , mice ; 1 , shrews ; 3 , birds."

Florence (47) examined fifteen examples. The summary of the stomach contents is as follows: " 3 contained birds; 1 , a mole; 2 , shrews ; 1 , field-mouse ; 1 , insect of indifferent group; 1 , earth ; 4, grass."

\section{Post-mortem Records.}

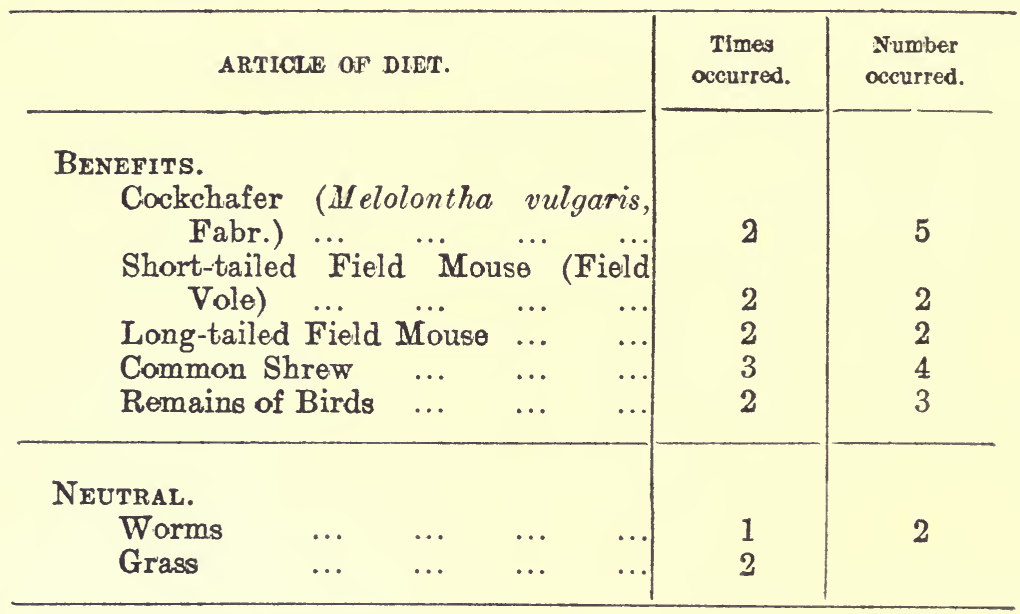

Examination of 108 Pellets.

\begin{tabular}{|c|c|c|c|c|c|c|c|}
\hline \multicolumn{7}{|c|}{ ARTICLE OF DIET. } & \multirow{2}{*}{$\begin{array}{c}\begin{array}{c}\text { Number } \\
\text { occurred. }\end{array} \\
1\end{array}$} \\
\hline Mole ... ... & $\ldots$ & $\cdots$ & $\cdots$ & $\ldots$ & $\ldots$ & $\cdots$ & \\
\hline Common Shrew & $\ldots$ & $\ldots$ & $\ldots$ & ... & $\ldots$ & ... & 47 \\
\hline Lesser Shrew & $\cdots$ & $\ldots$ & $\ldots$ & $\ldots$ & $\ldots$ & $\ldots$ & 5 \\
\hline Long-tailed Field & Mouse & $\ldots$ & $\ldots$ & $\ldots$ & $\ldots$ & $\ldots$ & 39 \\
\hline Brown Rat ... & $\ldots$ & $\ldots$ & $\ldots$ & $\ldots$ & $\ldots$ & $\ldots$ & 12 \\
\hline Short-tailed Field & Mouse & (Field & Vole) & $\ldots$ & $\ldots$ & ... & 34 \\
\hline Bank Vole ... & $\ldots$ & $\ldots$ & $\ldots$ & $\cdots$ & $\cdots$ & $\cdots$ & 7 \\
\hline Sparrow $\quad \ldots$ & $\cdots$ & $\ldots$ & $\cdots$ & $\ldots$ & $\ldots$ & $\cdots$ & 14 \\
\hline Thrush or Blackbi & & $\cdots$ & $\ldots$ & $\ldots$ & $\cdots$ & $\ldots$ & 4 \\
\hline
\end{tabular}

\section{Conclusion.}

There is no longer any doubt as to the value of this bird to the agriculturist, and it deserves all protection. 


\section{KESTREL.}

\section{Falco tinnunculus, Linn.}

During a few weeks of the year the kestrel undoubtedly does considerable harm, but apart from this period it is one of the most useful birds we have in its relation to agriculture.

Archibald (3) states: "Three facts about the kestrels should always be borne in mind. The first is that they very frequently bring up their young within easy reach of hand-reared game without taking a single chick, but, notwithstanding the temptation, continue to lead a life of harmless utility. Secondly, it is only during a very brief period of the game-bird's existence that any danger need be apprehended from the windhover, for it will not touch them except during their helpless infancy. Thirdly, throughout the rest of the year the kestrel does incalculable and unmixed good, by the destruction of hosts of field-mice and injurious beetles. The value of farm produce thus saved from destruction is almost beyond estimation. It is, therefore, a short-sighted policy to exterminate such beautiful and useful birds because they do a certain amount of harm, that harm being confined to a very few weeks in the year."

Smith (105) says: "The kestrel should be reckoned with the owl as one of our best friends, living on young rats, mice, black beetles, grasshoppers, and some small birds. Like the owl he will soon be exterminated if something is not done to preserve him from the gamekeeper."

Newstead (92) examined the stomach contents of nineteen specimens. He summarises them as follows: " 3 contained insects of the indifferent group ; 9 , voles ; 1 , mice ; 1 , frogs ; 1 , birds."

\section{Post-mortem Records.}

Only sixteen specimens have been examined.

\begin{tabular}{|c|c|c|c|c|}
\hline ARTICLE OF DIET. & & & $\begin{array}{c}\text { Times } \\
\text { occurted. }\end{array}$ & $\begin{array}{l}\text { Number } \\
\text { occurred. }\end{array}$ \\
\hline $\begin{array}{l}\text { BenEFITS. } \\
\text { Long-tailed Field Mouse } \\
\text { Short-tailed Field Mouse } \\
\text { Thrush or Blackbird } \\
\text { Nestling birds } \quad . .\end{array}$ & $\begin{array}{l}\cdots \\
\cdots \\
\cdots\end{array}$ & \begin{tabular}{l|}
$\cdots$ \\
$\cdots$ \\
$\cdots$
\end{tabular} & $\begin{array}{l}3 \\
4 \\
3 \\
4\end{array}$ & $\begin{array}{r}5 \\
12 \\
7 \\
9\end{array}$ \\
\hline $\begin{array}{l}\text { Neutral. } \\
\text { Earthworm remains } \\
\text { Beetle remains } \ldots\end{array}$ & $\begin{array}{l}\cdots \\
\cdots\end{array}$ & $\begin{array}{l}\cdots \\
\ldots\end{array}$ & $\begin{array}{l}1 \\
2\end{array}$ & \\
\hline
\end{tabular}




\section{Examination of Pellets.}

Newstead (92) examined fifty-seven pellets, which contained remains of 62 voles, 1 bird, and 5 indifferent insects.

Adams (1) states: "The analysis of the kestrels' pellets likewise determines its usual food. . . . Most of those that have come under my personal notice have been composed entirely of the wing-cases of all sorts of beetles and the wings of flies, and sometimes the remains of a small vole or mouse, but I have never discovered the remains of birds or rabbits."

\section{Field Observations.}

I have frequently seen this bird carry off sparrows and young blackbirds.

\section{Conclusion.}

The benefits this bird confers on agriculture, far outweigh the harm it does by its occasional and brief havoc amongst young game.

\section{SPARROW HAWK.}

\section{Accipiter nisus (Linn.)}

The sparrow hawk is undoubtedly too fond of game and poultry to merit protection, nevertheless, it destroys a considerable number of wood-pigeons, blackbirds, sparrows and mice, in addition to numerous insects.

Newstead (92) examined twelve specimens, and summarises the food contents as follows: "1 contained insects of the indifferent group; 11, birds; 1, frogs."

I hàve made post-morterns of six specimens, all of which con. tained remains of wild birds, most of which were blackbirds.

\section{Conclusion.}

I should not advocate any protection for this bird.

\section{WOOD PIGEON.}

Columba palumbus, Linn.

Some years ago, in a note on the food of this bird, which appeared in the Field, an anonymous writer described it as being "devoid of a single redeeming quality." For purposes of sport and food, however, they may be regarded as of some use, but from the standpoint of the farmer they are "wholly destructive and useless" (Newstead).

Gilmour (54) referring to the following table of injuries and 
benefits arrived at after examining the stomach contents of 265 birds,

\begin{tabular}{llll|r|r|r}
\hline \multicolumn{3}{r}{ Part of Plant used. } & & $\begin{array}{c}\text { Crops. } \\
\text { No. of times } \\
\text { taken. }\end{array}$ & $\begin{array}{c}\text { Trees. } \\
\text { No. of times } \\
\text { taken. }\end{array}$ & $\begin{array}{c}\text { Weads. } \\
\text { No. of times } \\
\text { taken. }\end{array}$ \\
\hline Roots $\ldots$ & $\ldots$ & $\ldots$ & $\ldots$ & 29 & 0 & 2 \\
Leaves & $\ldots$ & $\ldots$ & $\ldots$ & 79 & 1 & 23 \\
Flowers & $\ldots$ & $\ldots$ & $\ldots$ & 0 & 13 & 16 \\
Cereal grains & $\ldots$ & $\ldots$ & 123 & 0 & 0 \\
Qther fruits and seeds & $\ldots$ & 23 & 33 & 32 \\
\hline
\end{tabular}

States: "There is no uncertainty, no dubiety about the meaning here: the figures, as given by himself, condemn, and we cannot but convict. The root crops stand entirely against him; amongst the leaves, the clovers accuse him most strongly; and in the case of cereal grains no extenuation whatever for his outrage is offered. Though grain be left entirely out of count, the pigeon stands utterly condemned by the heavy black score still standing against him for root-crop and clover-leaf destruction."

Slater (104), Hooper (68), Theobald (109) and Newstead (92) all condemn this bird. Florence (47) examined eleven birds, and thus summarises the stomach contents: " 9 contained corn; 4, barley ; 3 , turnip-tops; 3 , peas ; 1 , beans ; 2 , beech nuts; 6 , weeds (leaves and seeds); 1 , holly seeds."

\section{Post-mortem Records.}

Three hundred and eighty-eight birds have been examined.

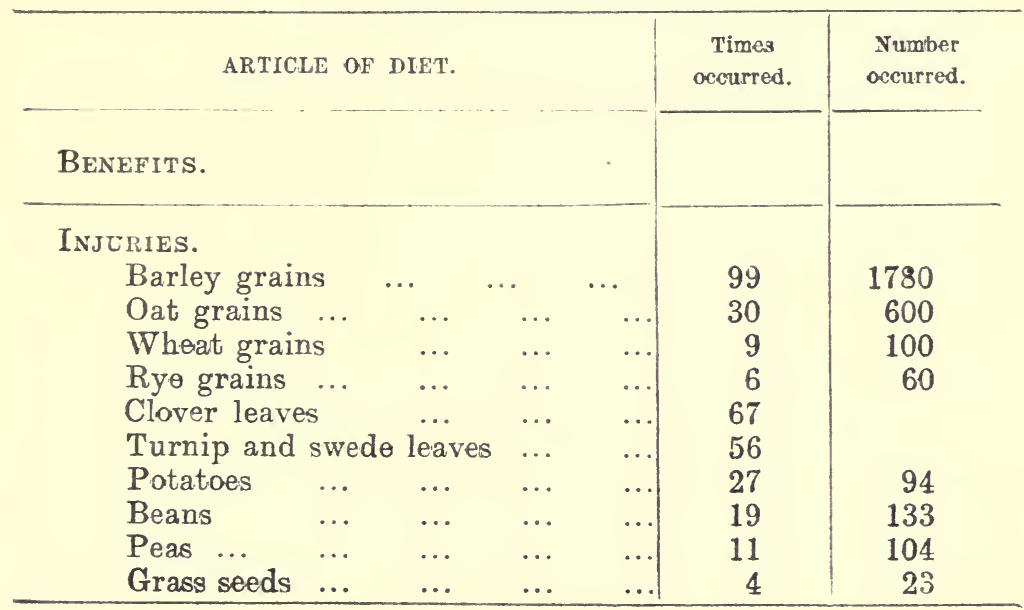


Neutral.

Seeds of

Charlock (Sinaspis arvensis, L.) ...

Chickweed (Stellaria media, L.) ...

Goosegrass (Potentilla anserina, L.)

Buttercup (Ranunculus repens, L.)

Curled Dock (Rumex crispus, L.)

Knotgrass (Polygonum aviculare,

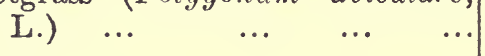

Leaves of

Lesser Celandine (Ranunculus

Fruits of

$$
\text { ficaria, L.) } \quad \ldots \quad \ldots \quad \quad \ldots
$$

Spurrey (Spergula arvensis, L.) ...

Beech Nuts ... $\quad \ldots \quad \ldots \quad \ldots$

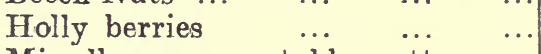

Miscellaneous vegetable matter, unidentifiable

\begin{tabular}{r|r} 
& \\
33 & 796 \\
9 & 215 \\
3 & 42 \\
8 & 124 \\
7 & 107 \\
3 & 19 \\
& \\
1 & \\
7 & \\
15 & \\
7 & \\
5 &
\end{tabular}

\section{Txamination of Faeces.}

A careful examination of large quantities of the faeces shows that many injurious weeds, such as charlock, dock, goosegrass, knotgrass, etc., are distributed by this species.

\section{Conclusion.}

There are no extenuating circumstances that lead me to alter the opinion formed many years back, that no quarter should be shown to this bird, and that every means should be taken to destroy it.

\section{STOCKDOVE.}

\section{Columba oenas, Linn.}

The feeding habits and food of this bird are very similar to those of the wood-pigeon, and practically all who have studied the bird condemn it.

In the thirty-four specimens examined by me, I could detect no difference in the nature of the food from that of the wood-pigeon, grain, clover, swede and turnip leaves, beans and peas, being in about the same proportions. 


\section{PLOVER.}

Vanellus vulgaris, Bechstein.

It would be difficult to exaggerate the value of this bird to the agriculturist. In many districts it has been greatly reduced in numbers owing to the destruction of its eggs. "There is no bird," writes Theobald (109) "more beneficial to the cultivator than the Lapwing. Its food consists entirely of wireworms, leatherjackets, surface larvae, snails, slugs, and many other injurious animals. The good done by the Lapwing cannot be overestimated: no one has said, or can say, a bad word against it. In spite of this, people are allowed to collect the eggs wholesale, and the demand increases, and, in consequence, in many parts the bird is decreasing. With this decrease goes a concomitant increase of wireworm and other grubs.

"Surely where, as in this case, we have an unanimous opinion, the somewhat useless and seldom-enforced Wild Birds' Protection Acts might be employed, so as to make it not only illegal to take the eggs, but to offer them for sale in shops."

The apathy displayed by agriculturists in regard to this very valuable bird forms a most striking illustration of how little they are able to help themselves, and the uselessness of their Chambers and Societies. Long ago the bird and its eggs should have been more strictly protected than game or any other birds. It is the farmer's best friend, and whilst his crops annually suffer more and more from wireworms and surface larvae, he stands and watches its gradual reduction with indifference.

\section{Post-mortem Records.}

I have purposely avoided destroying any large number of birds, only twelve examinations have, therefore, been made.

\begin{tabular}{|c|c|c|}
\hline ARTICLE OF DIET. & $\begin{array}{c}\text { Tinies } \\
\text { occurred. }\end{array}$ & $\begin{array}{l}\text { Number } \\
\text { occurred. }\end{array}$ \\
\hline 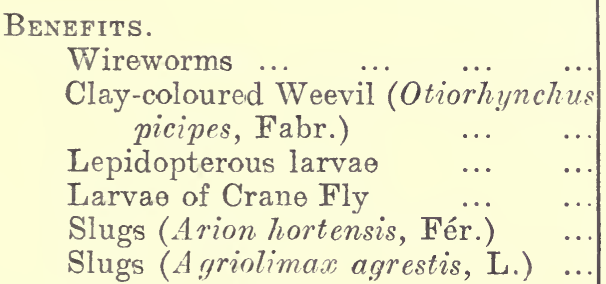 & $\begin{array}{l}2 \\
1 \\
3 \\
4 \\
3\end{array}$ & $\begin{array}{r}99 \\
9 \\
4 \\
26 \\
18 \\
22\end{array}$ \\
\hline
\end{tabular}


Neutral.

Seeds of

Buttercup (Ranunculus repens, L.)

Knotgrass (Polygonum aviculare,

L.)

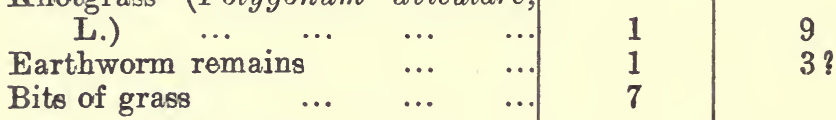

\begin{tabular}{l|l} 
& \\
1 & 4 \\
1 & 9 \\
1 & $3 ?$
\end{tabular}




\section{CHAPTER VI.}

\section{BIRDS AS DESTROYERS AND DISTRIBUTERS OF WEED SEEDS.}

"The problem of weed destruction is perennial in every land where agriculture is practised. Indeed, so serious is it, that soil culture may be said to be an everlasting war against weeds."

Sylvester D. Judd (72, p. 221).

\section{1.-Destruction of Weed Seeds.}

No one will deny that birds annually destroy a large quantity of the seeds of various weeds. The inspection of an acre of truck land in the autumn is recorded by Judd $(68, p .78)$ as giving some idea of the work of weed-destroying birds. "Crab-grass and pigeon-grass formed a low undergrowth, while lamb's-quarters, pigweed, and giant ragweed from 6 to 10 feet high rose in a thick weed forest. A flock of fifteen quail foraged in the centre of the area, twenty-five doves were scattered over the upper end, and fully two hundred native sparrows scurried about at the lower end, while a band of three hundred goldfinches clung to the ragweed stalks plucking off seeds.

"If we make the fair assumption that the birds remained on this acre of plenty long enough to obtain a full meal, we can reckon approximately the destruction wrought. At a moderate estimate twenty seeds apiece may be allowed for the goldfinches, one hundred for the sparrows, provided that they were from crabgrass or pigeon-grass, and five hundred for the doves and bobwhites, or a total of 46,000 seeds destroyed at a single breakfast."

Writing of the bobwhite, the same author refers to three coveys of these birds. In the first covey one bird was shot; seven from the second, and five from the third. The stomach contents were examined and showed that these thirteen birds had taken weed seed to the extent of 63 per cent. of their food. Thirty-eight per cent. consisted of ragweed, two per cent. of tick-trefoil, partridge pea, and locust seeds, and twenty-three per cent. of miscellaneous weed seeds. Although the stomachs and crops were not well filled, the birds had eaten 5,582 weed seeds.

In another case (p. 25) Judd records the finding of three hundred seeds of amaranth in the stomach of one Nuttall's sparrow, and three hundred seeds of lamb's-quarters in a second; in a tree sparrow seven hundred seeds of pigeon-grass were found, and in a snowflake (Passerina nivalis) were 1,500 seeds of amaranth. 
Beal (15) estimated the amount of weed seed eaten by various sparrows during their winter sojourn in the State of Iowa at about 875 tons.

\section{2.-Distribution of Weed Seeds.}

We have already seen that the food of many wild birds consists, for a considerable part of the year, of the seeds of weeds and other plants, and it has, all too hastily, been assumed that such seeds are destroyed, either before being swallowed or in their passage through the intestinal canal. Such, however, is not always the case.

Judd $(74$, p. 49) writing of the relation of sparrows to agriculture, states: "During January and February, 1900, a series of experiments was carried out to ascertain how far sparrows are responsible for the dissemination of the seeds upon which they subsist. The only birds available for these experiments were seven English sparrows, but the conclusions reached are, in a measure, applicable to all sparrows. The birds were fed on seeds of different weeds, and all their droppings were examined to ascertain the condition in which the seeds were voided. The seeds of climbing false buckwheat and ragweed were found to be thoroughly pulverized, although quite a number of small fragments of the black, shiny coats of the former were found in the droppings. This result was expected, since the birds crack these seeds before swallowing them. The seeds of lamb's-quarters and amaranth were next tried. These, because of their small size and hard structure, it was supposed, would be swallowed whole, and would partially escape destruction in their passage through the bird's digestive tract. But such proved not to be the case. The birds cracked them as they had the others. Halves of seed shells were found in the seed cup, and many broken smaller pieces; and the droppings of the birds showed no whole seeds, although some few empty split seeds with the two half-shells clinging together were found. Usually only the finely pulverized dust of the seed coats was found in the faeces. When the sparrows were not under experimentation they were fed chiefly on millet, the grain of which is inclosed by two corrugated siliceous glumes. These were similarly removed by the birds. No whole seeds were found in the dung, and only an occasional small piece of one of the glumes. The closely related seeds of pigeon-grass (Choetocloa viridis) are inclosed by much stronger glumes, but when these were fed to the birds the cracking of the grain and the removing of the glumes appeared to be just as complete as in the case of the millet, and seemed as certainly to preclude any possibility of subsequent germination.

"Some experiments were made with the seeds of crab-grass (Panicum sanguinale). A well-known firm of seedsmen suggested to 
the Department the probability that the English sparrow was responsible for the occurrence of crab-grass in lawns and golf links sown with pure seed of the finest brand. Much complaint was received from the buyers of lawn-grass seed because, after the seed was planted and the turf well-established, crab-grass appeared in it, often so thickly as to necessitate plowing under the whole lawn. Two sparrows were fed with 100 of the seeds. Instead of manipulating them as they did the seeds of millet and pigeon-grass they swallowed them whole, without removing any of the ensheathing glumes. Gravel was furnished so that the grinding power of the birds' gizzards might be facilitated, and after several hours six droppings were collected and examined. No whole seeds were found. There were, however, three nearly entire glumes and a pulverized mass of matter which, under the miscroscope, was seen to consist of fragments of broken glumes. Several days later about 500 crab-grass seeds were fed to the same sparrows, no gravel being given at the time or during the interval between the two experiments. Twelve droppings were examined and the results were substantially the same as in the first experiment. Three different sparrows were then fed with about 1,000 crab-grass seeds and twenty droppings were collected. The result was the same. Not one of the 1,000 seeds was passed in a condition to germinate. Although these experiments are by no means conclusive, yet they strongly indicate that the English sparrow, however harmful it may be in other ways, can not be held responsible for the occurrence of crab-grass in lawns."

It seemed desirable, in view of the statement of so careful an observer as Dr. Judd, to institute a series of experiments with the house sparrow and other birds, and the results obtained are set forth below.

In order to test to what extent, if any, different species of birds were instrumental in disseminating weeds, a quantity of soil was sterilised and then placed in ordinary flower pots, etc. Droppings of the different species were then collected and placed upon the soil and a little fine soil scattered above them. The following tables show the number of plants and species that were thus cultivated, and the number of droppings examined.

\section{House Sparrow.}

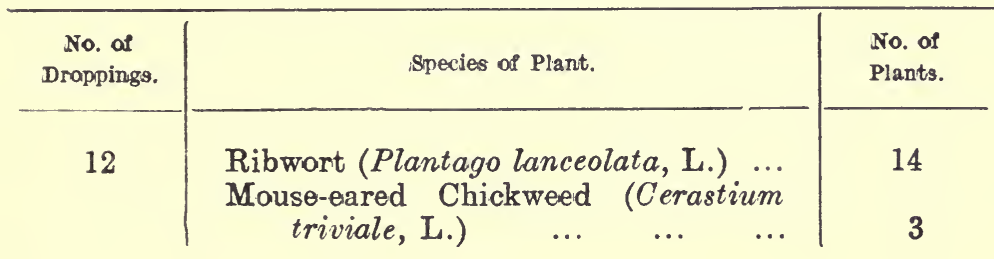




\begin{tabular}{|c|c|c|}
\hline & Groundsel (Senecio vulgaris, L.) & 12 \\
\hline 6 & Ribwort (Plantago lanceolata, L.). & 5 \\
\hline 6 & Ribwort & 9 \\
\hline \multirow[t]{2}{*}{10} & Sheep's Sorrel (Rumex acetosella, $\mathrm{L}$.) & 10 \\
\hline & $\begin{array}{lllll}\text { Ribwort } & \ldots & \ldots & \ldots & \ldots\end{array}$ & 19 \\
\hline \multirow[t]{3}{*}{12} & Daisy (Bellis perennis, L.) & 22 \\
\hline & Ribwort $\quad \ldots \quad \ldots$ & 13 \\
\hline & Mouse-eared Chickweed $\quad \ldots$ & 7 \\
\hline \multirow[t]{3}{*}{8} & Yarrow (Achillea millefolium, L.) & 8 \\
\hline & Croeping Buttercup (Ranunculu & \\
\hline & repens, L.) & 11 \\
\hline 54 & No. of species of weeds & 133 \\
\hline
\end{tabular}

A careful examination was made of thirty-five droppings and the following perfect seeds were obtained: 22 Ribwort, 14 Buttercup, 3 Dandelion, 7 Chickweed, 9 Sheep's Sorrel, 8 Yarrow, 8 Dock, 4 Daisy, 10 Groundsel. follows :-

In regard to the bullfinch and greenfinch the results were as Bullfinch.

\begin{tabular}{|c|c|c|}
\hline $\begin{array}{l}\text { No. of } \\
\text { Droppings. }\end{array}$ & Species of Plant. & $\begin{array}{l}\text { Yo. of } \\
\text { Plants. }\end{array}$ \\
\hline 8 & $\begin{array}{ll}\text { Self-heal (Prunella vulgaris, L.) } & \ldots \\
\text { Charlock (Sinaspis arvenis, L.) } & \ldots \\
\text { Ribwort (Plantago lanceolata, L.) } & \ldots\end{array}$ & $\begin{array}{l}5 \\
3 \\
4\end{array}$ \\
\hline 15 & 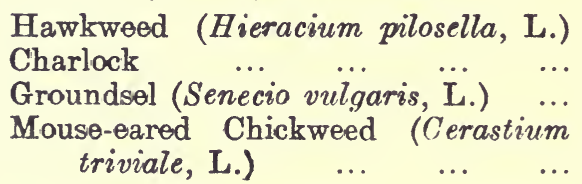 & $\begin{array}{r}8 \\
7 \\
11 \\
9\end{array}$ \\
\hline 14 & 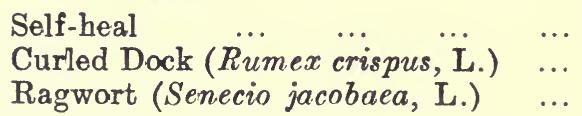 & $\begin{array}{r}3 \\
12 \\
5\end{array}$ \\
\hline 10 & $\begin{array}{lcccc}\text { Sow Thistle (Sonchus oleraceus, L.)... } \\
\text { Hawkweed } & \ldots & \ldots & \ldots & \ldots \\
\text { Self-heal } & \ldots & \ldots & \ldots & \ldots\end{array}$ & $\begin{array}{r}11 \\
6 \\
3\end{array}$ \\
\hline 3 & $\begin{array}{llll}\text { Sow Thistle } & \ldots & \ldots & \ldots \\
\text { Curled Dock } & \ldots & \ldots & \ldots\end{array}$ & $\begin{array}{l}5 \\
4\end{array}$ \\
\hline 50 & No. of species of weeds & 96 \\
\hline
\end{tabular}


Birds as Destroyers and Distributers of Weed Seeds.

Greenfinch.

\begin{tabular}{|c|c|c|}
\hline $\begin{array}{l}\text { No. of } \\
\text { Droppings. }\end{array}$ & Species of Plant. & $\begin{array}{l}\text { No. of } \\
\text { Plants. }\end{array}$ \\
\hline 6 & $\begin{array}{ll}\text { Charlock (Sinaspis arvenis, L.) } & \ldots \\
\text { Curled Dock (Rumex crispus, L.) } & \ldots \\
\text { Ribwort (Plantago lanceolata, L.) } & \ldots\end{array}$ & $\begin{array}{l}4 \\
5 \\
3\end{array}$ \\
\hline 14 & $\begin{array}{l}\begin{array}{l}\text { Curled Dock } \\
\text { Dandelion }\end{array} \text { (Taraxacum } \quad \text { officinale, } \\
\text { Wigg.) } \\
\text { Knotweed (Polygonum aviculare, L.) }\end{array}$ & $\begin{array}{l}7 \\
6 \\
9\end{array}$ \\
\hline 8 & Goose-grass (Galium aparine, L.) ... & 5 \\
\hline 10 & $\begin{array}{cccc}\text { Corn Marigold } & \text { (Chrysanthemum } \\
\text { segetum, L.) } & \ldots & \ldots & \ldots\end{array}$ & 13 \\
\hline 38 & No. of species of weeds & 52 \\
\hline
\end{tabular}

Kerner (79) remarks that: "The modes of dispersion of fruits and seeds through the agency of animals are almost as varied as the different methods of dissemination by the wind. In many cases such dispersion is brought about by the animals using the fruits and seeds in question for food; the undigested parts are excreted, and any embryos which may have survived the passage through the alimentary canal subsequently germinate." As the fact of this mode of dispersion has been a matter of dispute amongst botanists, and could only be established by experiment, Kerner determined to feed various animals with selected fruits and seeds, and to ascertain, first of all, whether the embryos preserve their vitality after passing through an animal's intestinal canal. For this purpose he took fruits and seeds belonging to two hundred and fifty different species of plants and fed them to the following birds:-Blackbird, song-thrush, rockthrush, robin, jackdaw, raven, nutcracker, siskin, goldfinch, serinfinch, titmouse, bullfinch, cross-bill, pigeon, fowl, turkey, and duck; and also the following mammals: Marmot, horse, ox, and pig. "The faeces were examined after each meal, to ascertain what seeds they contained, and were then laid on a separate bed of earth, and at the same time fruits and seeds of the same plants which had not been used for food were planted in an adjoining bed. It would be out of place to set forth here all the precautions which it was necessary to take in conducting these laborious researches; a statement, however, of the most important results obtained from five hundred and twenty separate experiments will suffice for our purpose."

The birds resolved themselves into three groups in relation to the matter in question. The first group includes those which grind up even the hardest fruits and seeds in their muscular gizzards, 
which are, in addition, usually filled with small stones and sand. Amongst these, some strip the fruits and seeds when they first lay hold of them, and thereby condemn them to destruction. To this group the following birds of those employed in the experiments belong, viz., the turkey, the common fowl, the pigeon, the duck, the cross-bill, the bullfinch, the goldfinch, the siskin, the serin-finch, the nutcracker, and the titmouse. No seed, under ordinary conditions, was found capable of germination, in the excrement of these birds; only when on a few occasions food was forcibly administered to the fowl and to ducks, so that their crops must have been overloaded, were a few seeds found to have escaped pulverization, and to still possess the power of development. The seeds used were those of Arenaria serpyllifolia, Papaver rhaeas, Sisymbrium sophia, Ribes rubrum, Ligustrum vulgare, Fragaria indica, and other species.

Ravens and jackdaws form a second group, in that the stones of the drupes and hard-coated seeds of the berries which they ate passed uninjured through the intestine, whilst soft-coated seeds and fruits were all destroyed. Kerner emphasises the fact that after these birds had been fed with cherries their excrements contained cherry-stones $15 \mathrm{~mm}$. in diameter, every one of which was able to germinate. Of the birds selected for experiment, the blackbird, the song-thrush, the rock-thrush, and the rabin formed the third group. Of these the blackbird was the least fastidious about its food. It even swallowed the fruits of the yew without afterwards relieving its crop of the stony seeds, and it never rejected a single fruit that was mixed with its food. The song-thrush refused all dry fruits of $5 \mathrm{~mm}$. in diameter or more, even when they were mixed with the finely-chopped meat with which the bird was fed. They also avoided certain strong-smelling fruits, such as that of the yarrow. On the other hand the aromatic fruits of Umbelliferae (e.g., Bupleurum rotundifolium and Carum carvi) were eaten with great avidity. The seeds of the tobacco-plant, henbane, and foxglove mixed with the food were not rejected and caused no ill effects, neither did the berries of the deadly nightshade, which were greedily devoured. On the other hand, however, a song-thrush sickened after eating berries of Phytolacea. When fleshly fruits with seeds of diameter exceeding $5 \mathrm{~mm}$., such as those of Berberis, Ligustrum, Opuntia, and Viburnum were introduced into the crop, the pulp passed into the gizzard, but all the seeds were thrown up. Many seeds, as, for example, those of Lychnis fos-jovis, were carefully removed from the rest of the food with which they had been mixed. The seeds of fleshy fruits which were greedily devoured were thrown out of the crop if, the stones which they enclosed measured as much as $3 \mathrm{~mm}$.

The interval of time between ingestion and evacuation in those species belonging to the third group was surprisingly short. 
thrush fed with Ribes petraeum at 8 a.m. excreted numbers of the seeds after the lapse of three-quarters of an hour, and seeds of Sambucus nigra were found to have passed through the alimentary canal in half an hour; but the majority of seeds took from one and a half to three hours to perform the journey. Curiously enough, the small smooth fruits of Myosotis sylvatica and Panicum diffusum were retained for the longest period.

Kerner goes on to observe that of the fruit and seeds which passed through the intestine, 75 per cent. germinated in the case of the blackbird, 85 per cent. in the case of the thrush, 88 per cent. in the case of the rock-thrush, and 80 per cent. in the case of the robin. The germination of fruits and seeds that had undergone ingestion and excretion was usually (i.e., in from 74 to 79 per cent. of the cases), tardy as compared with that of similar fruits and seeds which had not been treated in this way, but were only germinated for the purpose of comparison. In the case of a few berries, however, e.g., Berberis, Ribes, Lonicera, the period of germination was hastened by this ingestion; while the seeds of such plants as grow on richly-manured soil, e.g., A maranthus, Polygonum, Urtica, after passing uninjured through the intestines, produced stronger seedlings than did those which were cultivated without such preliminaries.

"From these experiments we may assume that the dispersion of edible fruits through the agency of thrushes and blackbirds is not, as was formerly supposed, an exceptional phenomenon obtaining in the mistletoe only, but one that may take place in the case of many other plants, and other observations prove that, as a matter of fact, it does take place. Plants possessing fleshly fruits are undoubtedly disseminated in this manner. The occurrence of such plants as epiphytes upon trees, and also their unexpected appearance on the tops of high rocks and old walls thus receives a natural explanation.

"Seeing that the seeds and stones containing seeds of the fleshly fruits eaten by thrushes and blackbirds only remain a short time in the crop and intestine of the bird, it is probable that the plants in question are disseminated by this agency to the distance of a few leagues at most, in the course of a single year, and that it takes many years to distribute them, step by step, as it were, over large areas. We may reasonably suppose that distribution is affected principally in the direction of those parts of the world towards which thrushes and blackbirds are in the habit of journeying by short daily stages when autumn, the season of the maturity of most fleshly fruits, sets in.

"It is well known that nutcrackers, jays, squirrels, and marmots, keep stores of food in larders, which they fit up in holes 
in rocks, or in the earth, or in some other secret hiding-place of the kind, and that such fruits and seeds as they conceal there are liable to be left permanently for one reason or another. The hiding-place may be forgotten, or, as is still more likely, the creature that occupied it may fall a victim to a bird of prey. The fruits and seeds may then germinate in the place of concealment, and, inasnuch as the latter is always more or less distant from the spot whence the fruits were taken, this must also be accounted one of the modes of dispersion of the plants in question. I have myself observed this curious phenomenon also in the case of the dissemination of the arolla Pine (Pinus cembra) by nutcrackers, of beeches, oaks, and hazels by jays, and of hazels by squirrels.'"

Pycraft (99) refers to the valuable evidence on this subject brought together by Ridley, "who found that in the Malay Archipelago the principal carriers were bulbuls, the dark-blue starling (Calornis chalybca), the minah (Mainatus savatus), and the horn-bills (Buceros, Anthracoceros, etc.), the latter being especially fond of the nutmeg. The parrots of the genus Palaeornis also aided in this work. The granivorous finches of the genus Munia he found aided considerably in the dispersal of adhesive seeds, which were carried about by the feathers and finally dropped. $\mathrm{He}$ states, on the authority of Mr. G. Clunies Ross, that on Cocos Islands "when boobies are not nesting, and have consequently left, the frigate-birds (Tachypetes aquila) are unable to procure their ordinary food, which consists of fish taken from the boobies, and that they then swallow seeds of Guilandina and beans which they find floating on the sea, and on flying to the land vomit them up again, apparently merely using them to fill up temporarily empty crops!"”

Darwin* mentions that: "In the course of two months I picked up in my garden twelve kinds of seeds, out of the excrement of small birds, and these seemed perfect, and some of them, which were tried, germinated. But the following fact is more important: the crops of birds do not secrete gastric juice, and do not, as I know by trial, injure in the least the germination of seeds ; now, after a bird has found and devoured a large supply of food, it is positively asserted that all grains do not pass into the gizzard for twelve or even eighteen hours. A bird in this interval might easily be blown to the distance of 500 miles, and hawks are known to look out for tired birds, and the contents of their torn crops might thus readily get scattered. Some hawks and owls bolt their prey whole, and, after an interval of from twelve to twenty hours, disgorge pellets, which, as I know from experiments made in the Zoological Gardens, include seeds capable of germination. Some seeds of the oat, wheat, millet, canary, hemp, clover, and beet germinated after

*Origin of Species, 6th ed. 1902, p. 510. 
having been from twelve to twenty-one hours in the stomachs of different birds of prey; and two seeds of beet grew after having been thus retained for two days and fourteen hours."

"Other and unknown agencies probably have also played a part. I have stated that fresh-water fish eat some kinds of seeds, though they reject many other kinds after having swallowed them; even small fish swallow seeds of moderate size, as of the yellow water-lily and Potamogeton. Herons and other birds, century after century, have gone on daily devouring fish; they take flight and go tc other waters, or are blown across the sea; and we have seen that seeds retain their power of germination when rejected many hours afterwards in pellets or in the excrement." (p. 539).

Beal (c. 17, p. 74) has shown that the Wren Tit (Chamaea fasciata), the California Thrasher (Toxostoma rediviva), and other species disseminate the seeds of poison oak (Rhus diversiloba).

Judd (75, p. 62) writing on this subject, states: "The large consumption of wild fruit results in a wide distribution of seeds, which are voided by birds and germinate where they are dropped. Some observations on crows will illustrate this dispersion.

"On November 17th, 1899, a large flock on the wing was noticed in the distance, . . . they came on down the river in a line that, at times, stretched almost from one bank to the other. The flock numbered at least a thousand, and hoarse caws and croaks gave evidence that it was made up to some extent of fish crows. After the birds had remained on the shore fifteen minutes they were put to flight by a farmer's boy, and flew on down the river, lessening to specks, and finally disappearing on the horizon.

"Going to the place where they had alighted, I found the sandy beach cut up for more than a hundred yards with their tracks. Many led out to the water, and floating black feathers here and there showed where baths had been taken. The most interesting trace of their sojourn, however, was several hundred pellets of fruit material which they had ejected through their mouths and dropped on the ground.

"These pellets were about an inch in length and half an inch in diameter. They were of a deep purplish colour, due to the fruit of woodbine, wild grape, and pokeberry, of which they were mainly composed. In fifty pellets collected there were only eleven seeds of other plants-namely, holly, bitter-sweet, and poison ivy. Pokeberry seeds were by far the most numerous. Mr. A. J. Pieters, of the Botanical Division of the [U.S.] Department of Agriculture, germinated some of them, thus demonstrating the fact that they were distributed uninjured. 
"Little is known of the distribution of fruit seeds by crows during migration, but it is certain that they do this work effectively while they fly to and from the roosts where they congregate in winter, for their feeding grounds often cover an area stretching out on all sides from the roost for fifty miles or more."

The same writer records visiting in February, 1901, a crow dormitory, in which probably 100,000 birds slept every winter night. He found strewn on the ground the disgorged pellets which contained the seeds of poison ivy, poison sumac, and other sumacs, smilax, cedar, sour gum, and flowering dogwood.

On March 27th, 1901, a two hours' search was made beneath a large black walnut tree, remote from other woody vegetation. In all 172 fruit seeds were found, including mulberry, cultivated cherry, wild black cherry, wild grape, woodbine, pokeberry, cedar, sassafras, blackberry, and sumac.

Numerous other cases might be cited, but it will suffice to record one instance that came under my own observation a short time ago. A number of sycamore seedlings were noticed in a newly. made garden enclosed by a high fence, and as the nearest trees of that species were nearly a mile away, it was concluded that the seeds had been washed off the fence, by the rain, from some bird droppings. In order to settle the matter I carefully collected a large supply of droppings from the fence and placed the same in sterilised soil. The following plants were grown:-Sycamore (Acer pseudo-platanus), ribwort-plantain (Plantago lanceolata, Linn.), mouse-ear chickweed (Cerastium triviale, Linn.), broadleaved dock (Rumex obtusifolius, Linn.), groundsel (Senecio vulgaris, Linn.), and charlock (Sinaspis arvensis, Linn.).

Although many writers hold the opinion that seed-eating birds are as a class beneficial, I cannot regard them as such, for, to a much larger extent than is generally supposed, they act as distributers of the seeds of weeds. Mason (89) believes that in India birds which eat weed-seeds are of no value whatever and observes that: "they may keep weeds down to a certain extent, but this is of minor importance in a country where labour is cheap and where farming is not practised on such intensive lines as elsewhere. Even in intensive cultivation we cannot rely on weeds being kept down by birds, and the expense of cultivation to eliminate weeds is, I believe, not reduced in the slightest by the action of birds. We cannot expect the complete elimination of any one of the commoner weeds by the agency of birds alone. If any species of bird fed almost entirely on one species of weed and there seemed to be every possibility of that weed being eliminated, the bird, finding its food supply diminishing, would migrate." 


\section{CHAPTER VII. \\ BIRDS IN RELATION TO FORESTRY.}

" Interference with the balance of Nature must only be undertaken with knowledge and discretion."
O. Hermann (64, p. 381).

The wild birds that are directly hurtful to for ests in this country are happily few in number, whilst the majority of species found in or near forests are distinctly beneficial.

The destructive species destroy buds, young shoots, and seedlings, they scratch up sowings and seed beds, feeding upon the seeds. Some damage or eat the fruits, whilst a few do damage to the trees by making holes in them.

Of the beneficial species, those which destroy such small mammals as field mice, voles, shrews, moles and rabbits, are ex tremely valuable, as well as the purely insectivorous species.

The chief destructive species are:

Siskin, Chrysomitris spinus (Linn.).

Greenfinch Ligurinus chloris (Linn.).

Hawfinch, Coccothraustes vulgaris, Pall.

Chaffinch, Fringilla coelebs, Linn.

Bramling, Fringilla montifringilla, Linn.

Crossbill, Loxia curvirostra, Linn.

Nutcracker, Nucifraga caryocatactes (Linn.).

Jay, Garrulus glandarius (Linn.).

Great Spotted Woodpecker, Dendrocopus major (Linn.).

Lesser Spotted Woodpecker, Dendrocopus minor (Linn.).

Green Woodpecker, Gecinus viridis (Linn.).

Wood Pigeon, Columba palumbus, Linn.

Stock Dove, Columbacenas, Linn.

Turtle Dove, Turtur communis, Selby.

Capercaillie, Tetrao urogallus, Linn.

Black Grouse, Tetrao tetrix, Linn.

Pheasant, Phasianus colchicus, Linn. 
The extent to which these cause injury varies according to local and other circumstances. The actual amount of damage, however, seldom assumes serious proportions. The injury caused by finches is mainly to fruits and seeds, sometimes they prove very destructive to sowings; at the same time, it must be remembered that for part of the year their food consists of weed-seeds and insects.

The crossbills are mainly injurious to the cones of Scote pine and spruce, as are the nutcracker and jay, only to a much greater extent.

Much diversity of opinion exists as to the precise economic status of the woodpeckers. On the one hand they are described as destructive from the fact that they peck holes in various species of trees, they wound saplings, eat the seeds of numerous forest trees, and at times girdle trees.

On the other hand, they destroy large numbers of some of the worst forest insects known, e.g., Pissodes pini, Linn., and Pissodes notatus, Fabr.; Hylastes ater, Pk., the Black Pine Beetle; Myelophilus piniperada, Linn., the Pine Bark Beetle, also the larvae of various other beetles, moths, sawflies, etc.

Fisher (45a, p. 143) writes: "Opinions regarding the utility or otherwise of woodpeckers from a forestry point of view have varied from time to time. Towards the end of the eighteenth century they were considered hurtful by pecking holes into trees which were sometimes sound ones.

" In Beckman's " Handbuch der Jagdwissenschaft," published at Nuremberg in 1802, this opinion was adopted, and in consequence a reward of 2d. per head was offered in Germany for their destruction. Bechstein was the first, in 1802 , to consider them useful, and Walther in 1803 ; also Gloger about 1860. Foresters then went to the other extreme, considering woodpeckers as extremely active in destroying insects, and ignoring their propensity for making holes in trees. Altum in his "Forst-zoologie" reverted to the former opinion, stating that woodpeckers were practically useless against dangerous bark-beetles, but attacked the larger and less important longicorn-beetles, and that they themselves did considerable damage to trees.

"Altum wished, however, to protect woodpeckers on aesthetic grounds, because they enliven the forest and please the eye. Judeich follows Altum's views to a certain extent. König, Döbner, Vogt, the brothers Müller, Taschenberg, Borggreve, Nördlinger, and others consider that the utility of woodpeckers outweighs the harm they may do, and Hess expresses himself as of the same opinion, from the most recent observations on the subject." 
More recently Beal (19a) has dealt with the American species in an exhaustive manner.

The wood-pigeon and its relatives eat up seeds and do much harm to seedlings. Complaints have also been received of them setting upon young trees and breaking the branches.

The amount of damage done by game birds to forests has been considerably exaggerated. The capercaillie undoubtedly in'jures forest nurseries as well as the buds and young shoots of various conifers. On the other hand it destroys many injurious insects, and it affords both sport and food. The black grouse and pheasant, although both are included amongst the destructive species, are, in my opinion, far more beneficial than injurious. Grimshaw (56) has recently set forth in some detail the crop contents of a single bird, which are as follows:-

\section{Analysis of Contents.}

Insects-Diptera: Bibio lepidus, Lw. Pollenia rudis, Fab. 2,286 specimens 1 , Coleoptera: Lochmaea suturalis, Thoms. (Heather Beetle) ... ... ... Hymenoptera : Myrmica rubra, L. (Ant) Orthoptera: Stenobothrus sp. (Grass-

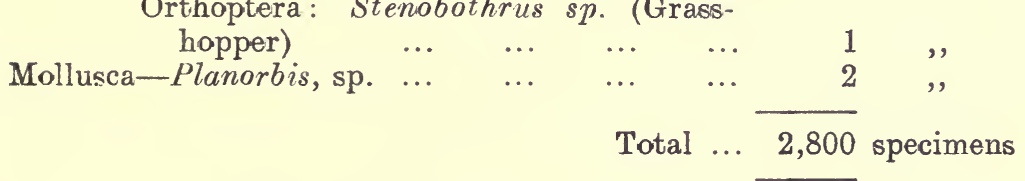

$508 \quad$,

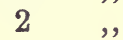

-

Vegetable remains.-Numerous tubers of Lesser Celandine (Ranunculus ficaria), one seed-capsule of Mouse-Ear Chickweed (Cerastium), fragments of mosses and grasses, small stem with leaves of Heath Bed-straw (Galium saxatile), tiny shoots of Heather (Calluna vulgaris), many fragments of leaves of the Bulbous Crowfoot (Ranunculus bulbosus), and a few leaflets of the Cuckoo-flower (Cardamine pratensis).

On the whole we may state that birds in this country do not commit any serious amount of damage to forests. On the other hand the beneficial species are excoedingly valuable. Of these, those concerned in the destruction of "forest vermin " are, perhaps, the most important, such, for example, as the Barn Owl (Strix flammea, Linn.), the Tawny Owl (Syrnium aluco (Linn.)), and other species, and the Kestrel (Falco tinnunculus, Linn.). Fortunately, we now have carefully recorded acoounts of the stomach contents of these birds, and also of the nature of the castings or pellets (see p 62) 
Writing of the common field vole Fisher (45a) states that it " is the greatest scourge of the agriculturist, and comes from the fields into light forests, where it does enormous damage."

A description of the damage done in 1814 by this species and the long-tailed field mouse is given in Nicholls' account of the Forest of Dean. They destroyed all the young oak-saplings in the forest except four or five per acre, eating through the roots just below the ground. The long-tailed species was found chiefly on wet ground, and the vole everywhere. To exterminate these pests, trenches two feet deep were dug twenty yards apart, and 100,000 tails were brought in for reward. The voles breed much more rapidly than mice. In one species, which gives birth to eight or ten young every six to eight weeks, from March till late autumn, the female commences to breed when eight weeks old, and it has been estimated that she may have as many as 10,000 descendants in a year.

When we call to mind the immense damage done by voles, shrews, mice, etc., to agricultural crops in addition to forest trees, and realise that the bulk of the food of owls consists of these animals, it does indeed seem strange that birds, that should be protected by very stringent laws, are so ruthlessly destroyed.

The Long-eared Owl (Asio otus (Linn.)), and the Short-eared Owl (A sio accipitrinus (Pall)), although not so common as the two previously mentioned species, are equally beneficial.

The Kestrel (Falco tinnunculus, Linn.), is another persecuted bird, that confers far more good than it does harm. The greater portion of its food consists of mice, beetles and their larvae. It occasionally causes sad havoc amongst young pheasants, but not infrequently it is blamed for the misdeeds of the Sparrow Hawk.

Of the insectivorous birds none is of more importance to the forester than the Nightjar or Goatsucker (Caprinulgus europaens, Linn.), unfortunately it is still destroyed and classed as a Hawk by that large class of men known as unintelligent gamekeepers.

\section{Remedial and Protective Methods.}

Much can be done to prevent damage to sowings and nursery seed-beds by protecting them with wire-netting or covering them with branches of hawthorn.

The provision of nesting boxes in forests for insectivorous birds is becoming more and more necessary. Merely to protect these birds is not sufficient: their multiplication must also be looked after. 
Where too plentiful, finches should be shot, as also wood pigeons, but as the former destroy numerous insects, this action should not be taken unless actually necessary. As Beal (12) remarks : "After years of misdirected effort, man is at last learning the lesson that Nature's adjustments are not to be lightly set aside; that when undisturbed by his influence each species maintains a certain normal maximum of abundance at which it does the most good and the least harm; and that its fluctuations either above or below this normal are temporary and local-from which it follows that his best efforts should be directed to restore and maintain this harmony, and, in all places where he is obliged to disturb it, he should seek for means of counterbalancing the mischief. In the case of insect depredations, while more immediate remedies may be necessary at first, there is little room for doubt that the protection and encouragement of insectivorous birds offer, in most cases, the surest means of relief." 


\section{CHAPTER VIII.}

\section{LEGISLATION.}

"The farmer has only recently learned to appreciate the full value of birds as insect destroyers. More exact knowledge of their food liabits has resulted in a higher estimate of their utility on the farm, and demonstrated more clearly than ever the necessity of active measures to insure their protection."

T. S. Palmer (97).

Apart from those birds protected by the Game Laws, no wild birds in the United Kingdom were protected by law until the year 1880 , and there is ample evidence that many species distinctly beneficial, e.g., kestrel, barn owl, etc., were considerably reduced in numbers, whilst others, once common, were becoming scarce or had already disappeared from our fauna, e.g., bustard, bittern, reeve, etc.

Prior to the year 1880 , and to a lesser extent since, gamekeepers ruthlessly destroyed all species which they thought to be injurious to game, and others about which they were generally ignorant. These depredations have been further assisted by a class of people known as collectors-pseudo-scientific students of birdlife who revel in large collections and rarities of both eggs and birds, and in no way related to the scientific ornithologist. Finally, many farmers, fruit-growers, and others interested in raising crops, destroyed most species without discrimination.

The Act of 1880 is a curious one and clearly evidences how little its framers know or thought of the interests of farmers, fruit-growers, etc. It enacts that between March 1st and August 1st any person taking or killing any wild bird shall, for the first offence be reprimanded and pay the costs of the prosecution, for subsequent offences a fine not exceeding $5 \mathrm{~s}$. and costs would be imposed. Owners or occupiers of land, and those authorised by them were exempted from this clause.

It further provides that a fine not exceeding $£ 1$ should be imposed on any person taking or killing any wild bird in the Schedule of the Act between March 1st and August 1st. 
The Schedule is a curious one, omitting, as it does, practically all the commoner insectivorous species, and enumerating many rare visitors to this country, whilst certain species were indicated by their local names only (bouxie, purre, tystey, etc.). Most of the sea-birds were included.

In the following year a second Act was passed, which explained Clause 3 of the 1880 Act, and added the name of the lark to the Schedule.

Not until the year 1894 was anything further done. In that year a further Act was passed whereby the Secretary of State, upon application by a County Council, may, by order, prohibit the taking or destroying of wild birds' eggs in any year or in any place within that county: or of the eggs of any specified kind of wild bird that they may recommend; or that the principal of the Act of 1880 may be extended to apply to any species of wild bird not included in the Schedule of the Act. The fine for taking or destroying eggs to be a sum not exceeding $£ 1$ for each egg.

Two years later, the Act of 1896 , ignores the County Cuuncils and reverts to Sec. 8 of the 1880 Act, whereby, on application by the justices in Quarter Sessions, the powers under that section are extended to the taking and killing of particular kinds of wild birds during those periods of the year not covered by the principal Act. Power is also given to forfeit any trap, net, snare, or decoy bird used for taking any wild bird.

A further short Act was passed in 1902 authorising the forfeiture of any wild bird or egg, in addition to the penalty mentioned.

Finally, in 1904, a really valuable Act was passed which provided a penalty not exceeding 40 s. for the first offence and $£ 5$ for every subsequent offence, for the use of pole traps.

After reviewing these Acts at somewhat greater length, a recent writer states: (1) "that they were all passed, not in the interests of agriculturists of any class, but to satisfy the outcry against bird destruction raised by the bird-loving public at large."

Although conceived with the best intentions, there is no evidence to show that the framers of these various Acts ever took seriously into account what would be the probable ultimate effect of their legislation. These effects are beginning to make themselves 
very seriously felt in many quarters, and it is now impossible to take up a paper without the probability of finding in its columns letters from fruit-growers, farmers, and gardeners complaining that their crops, both of fruit and grain, are destroyed wholesale by hordes of small birds.

Though this is probably the worst side to the question, and that most pressingly requiring amendment, there is another side that must not be forgotten.

The great increase of certain specially vigorous species, such as the rook, jackdaw, starling, and sparrow, is causing the destruction, indirectly, of other birds we can ill afford to lose.

The increase of rooks and jackdaws has definitely changed their habits, and, owing to the insufficiency of their natural food, such as grubs and worms, they have become almost purely predatory at certain times of the year in many places. Their wholesale destruction of game birds' eggs is well known to keepers. They also hunt systematically for the eggs of all ground-nesting birds such as grouse and plovers; and even the eggs of the smaller birds of prey and other tree-nesting birds often fall to their share.

The barn owl is now rarely seen in many districts where, until recently, it was very common. This is probably largely owing to the increased number of jackdaws, the result being that the owls are disturbed and their nests robbed by these pestilent and pertinacious marauders.

It may probably surprise many to learn that so recently as about the year 1830, a well-known old sportsman was unable to obtain a single specimen of a starling in the County of Northumberland, where they now exist in countless thousands, and had to send into Cumberland to get one for tying trout flies.

Again, house martins are seriously interfered with, and their eggs constantly destroyed by the ever-present house sparrows, who seize their nests as soon as they are constructed, and take no denial.

The Acts have certainly had their share in the results that have arisen. Village boys no longer dare go on bird-nesting expeditions, lest they fall into the clutches of the law. It is questionable whether the consequent ignorance concerning birds amongst the rising generation of country boys is altogether an advantage, and 
at any rate provision should have been made for reasonable relaxation in the case of bona fide collectors for scientific purposes, whilst at the same time some efficient stop should be placed on those who successfully and systematically trade in the eggs of our rarer birds in defiance of the law."

As Sir Walter Gilbey has so pertinently remarked (53) "Bird protection within reasonable limits is an excellent thing, but sentimental ideas cannot be allowed to over-ride practical considerations, and those who know the extent of the injury done by birds will agree that protection has been carried too far."

It is to be hoped that any future legislation will take into consideration the work of recent investigators; will have a definite object in view; and also be subject to revision at stated times and for different parts of the country according to varying conditions. 


\section{CHAPTER IX.}

\section{PROTECTIVE MEASURES.}

" I would submit that it is a matter for serious consideration, whether the great encouragement of bird-life beyond the natural balance, such as is now often recommended, may not lead to very contrary results to what is intended."

$$
\text { E. A. Ormerod, Rpt. Inj. Ins., 1883, p. v. }
$$

\section{The Planting of Wild Fruit Trees.}

It has been suggested (86) that it is desirable to plant in the neighbourhood of orchards, trees, the fruits of which are of little or no value to man, but which to birds are more acceptable than the cultivated kinds, such for instance as the Russian mulberry (Morus alba), the paper mulberry (Broussonetia papyrifera), the European bird cherry (Prunus padus), the choke cherry ( $P$. virginiana), the black cherry ( $P$. serotinia), the bird cherry ( $P$. pennsylvanica), the elders (Sambucus).

In introducing such trees into hedgerows, etc., it must be remembered that there is always the possible danger of their being a worse pest than the birds, as they might serve as breeding grounds for various insect pests injurious to cultivated fruits, particularly so the various species of Prunus.

\section{Bird Sanctuaries.}

Wherever special protection is provided with a view to encouraging or increasing bird life, great care is necessary. There can be little doubt but that the indiscriminate protection of wild birds has had much to do with the abundance of many species at the present time. In bird sanctuaries there is naturally a reluctance to destroy any birds, in consequence of which protection is afforded to species, which when present in large numbers become distinctly injurious. 
The enthusiastic bird-lover states: "We do not protect birds solely beeause they are useful, but chiefly from ethical and aesthetical reasons, as birds give beauty and animation to Nature. We also wish to preserve their species, and hence the protection of birds signifies the preservation of the monuments of Nature" $(66, p 18)$. The same arguments might logioally be advanced for the rat, the mosquito, and a host of other obnoxious animals.

From the work just quoted, I find that in 1906 on the Experimental Station at Seebach, the following birds, amongst others, were bred :-

200 pairs of linnets, 100 pairs of greenfinches, 5 pairs of song thrushes, 5 pairs of blackbirds, 10 pairs of goldfinches, 5 pairs of chaffinches, ànd 30 pairs of starlings.

\section{Drinking Water.}

It has frequently been stated that one of the reasons that birds attack fruit is to quench their thirst, certainly where there are facilities for olbtaining drinking water in the neighbourhood of orchards, the fruit has not suffered to anything like the extent of that where these facilities did not exist.

\section{Nesting Boxes.}

The provision of nesting boxes and nesting places for insectivorous birds is to be strongly recommended, and those described by Hiesemann in the work referred to above (66) meet the case admirably. 


\section{CHAPTER X.}

\section{SUMMARY AND CONCLUSHON.}

\section{our search." \\ "To try and find Truth is gain, even if we make mistakes in} LiCHTENBERG.

In the foregoing pages $I$ have set forth in considerable detail the results obtained from an examination of 3,048 post-mortems of adult birds, 312 post-mortems of nestling birds, large quantities of faeces, 191 pellets of two species, and observations made in the field, extending over the past eight years.

In all twenty-nine species have been examined (for List see p. 14), of these-five are distinctly injurious, viz., the house sparrow, bullfinch, sparrow-hawk, wood pigeon, and stockdove; six are two plentiful and consequently injurious, viz., missel thrush, blackbird, greenfinch, chaffinch, starling, and rook; one is injurious, but not plentiful, viz., the blackcap; the jay I regard as neutral, and the remaining sixteen as beneficial, most of them meriting protection, especially the owls, the wren, and the plover.

Numerous abservations have been brought forward regarding the frequency of the visits paid by the parent birds to their young, whilst in the nestling stage, also as to the nature of the food of the young birds.

Details as to the weed seeds distributed by wild birds are given and the results of extended examinations of the faeces, and of experiments made with such.

The relation of wild birds to forestry has been briefly reviewed, and the subjects of legislation and bird protection dealt with.

In conclusion, no one realises more than the author the shortcomings of such a work as this. The different methods of dealing with and tabulating extended observations and voluminous notes extending over a period of eight years, have presented many perplexing difficulties. To reduce such a series of data to a form that would be concise yet lucid has often proved a difficult task, but if I have at all succeeded in more clearly defining the precise economic position of the species of birds dealt with, I shall have been more than repaid. 


\section{BIBLIOGRAPHY.}

1. Adams, Lionel E.-A Plea for Owls and Kestrels.

Journ. Northamptionshire Nat. Hist. Soc., 1898, pp. 45-55, 1 plt.

2. Anon.-The Protection of Wild Birds.

Journ. Land Agents' Soc., 1906, vol. 5, pp. 559-565.

3. Archibald, C. F.-Wild Birds Useful and Injurious. Pt. I. Journ. R. Agric. Soc., 1892, vol. 3, pp. 658-684, 10 figs.

4. Pt. II., Ibid., 1894, vol. 5, pp. 60-84.

5. Archibald, C. F.-Wild Birds Useful and Injurious.

Journ. R. Agric. Soc., 1908, vol. 68, pp. 1-16.

6. Archibald, C. F.-A Few Notes on the Food of Wild Birds. Univ. of Leeds, Bull. No. 11, 1910, pp. 3-10.

7. Bailey, V.-Birds known to eat the Boll Weevil.

U.S. Dept. Agric., Biol. Surv., Bull. No. 22, 1905, pp. 1-16.

8. Barrows, W. B.-The English Sparrow (Passer domesticus) in North America, especially in its relation to Agriculture.

U.S. Dept. Agric., Div. Ornith., Bull. No. 1, 1889, pp. 1-405, 1 plt., 9 figs. and map.

9. Barrows, W. B., and E. 1. Schwarz.-The Common Crow of the United States.

U.S. Dept. Agric., Div. of Ornith. and Mam., Bull. No. 6, 1895, pp. 1-98, 1 plt. and 2 figs. 
10. Beal, F. E. L.-The Crow Blackbirds, and their Food. Yearbook U.S. Dept. Agric., 1894, pp. 223-248.

10a. Beal, F. E. L.-Preliminary Report on the Food of Woodpeckers.

U.S. Dept. Agric., Biol. Surv., Bull. No. 7, pp. $7-33,1$ plt. and 4 figs.

11. Beal, F. E. L.-The Meadow Lark and Baltimore Oriole. Yearbook U.S. Dept. Agric., 1895, pp. 419-430.

12. Beal, F. E. L.-Birds that injure Grain.

Yearbook U.S. Dept. Agric., 1897, pp. 345-354.

13. Beal, F. E. L.-How Birds affect the Orchard.

Yearbook U.S. Dept. Agric., 1900, pp. 291-304, 5 figs.

14. Beal, F. E. L.-Food of the Bobolink, Blackbirds, and Grackles.

U.S. Dept. Agric., Div. Biol. Surv., Bull. No. 13, 1900, pp. 1-77, 1 plt. and 6 figs.

15. Beal, F. E. L.-Some Common Birds in their relation to Agriculture.

U.S. Dept. Agric., Farmers' Bull. No. 54, 1904, pp. $1-48,22$ figs.

16. Beal, F. E. L.-The Relations of Birds to Fruit-growing in California.

Yearbook U.S. Dept. Agric., 1904, pp. 241-254.

17. Beal, F. E. L.-Birds of California in relation to the Fruit Industry. Pt. I.

U.S. Dept. Agric., Biol. Surv., Bull. No. 30, 1907, pp. 1-100, plts. i-v.

18. Beal, F. E. L.-Birds of California in relation to the Fruit Industry. Pt. II.

U.S. Dept. Agric., Biol. Surv., Bull. No. 34, 1910, pp. 1-96, plts. i-vi. 
19. Beal, F. E. L.-The Relations between Birds and Insects.

Yearbook U.S. Dept. Agric., 1908, pp. 343-350.

19a. Beal, F. E. L.-Food of the Woodpeckers of the United States.

U.S. Dept. Agric., Biol. Surv., Bull. No. 37, 1911, pp. 1-64, 6 plts. and 3 figs.

20. Beal, F. E. L., and S. D. Judd.-Cuckoos and Shrikes in their relation to Agriculture.

U.S. Dept. Agric., Div. Biol. Surv., Bull. No. 9, 1898, pp. 1-26, 1 plt. and 1 fig.

21. Berney, F. L.-The Food of the Birds.

Emu, vol. 7, pp. 79-81.

22. Bruner, L.-Birds in their relation to Agriculture.

Ann. Rpt. Nebraska State Bd. Agric., 1900, 1901, pp. 210-221.

23. Bryant, H. C.-The Relation of Birds to an Insect Outbreak in Northern California during the Spring and Summer of 1911.

The Condor, 1911, vol. 13, pp. 195-208.

24. Bryant, H. C.-The Economic Status of the Meadowlark in California.

Mon. Bull. State Comms. Hort., Sacr., Cal., 1912, vol. 1, pp. 226-231, 2 figs.

25. Bryant, H. C.-Some Insects and other Arthropods in the Diet of the Western Meadowlark.

Pomona Coll. Journ. Entom., 1912, vol. 4, pp. 807-809.

26. Cathcart, Earl.-Wild Birds in relation to Agriculture.

Journ. R. Agric. Soc., 1892, vol. 3, pp. 325-338. 
27. Cleland, J. B.-Examination of the Contents of Stomachs and Crops of some Australian Birds.

Emu, 1910, vol. 9, pp. 219-226.

28. Cleland, J. B.-Examination of Contents of Stomachs and Crops of 57 Australian Birds.

Agric. Gaz., Sydney, N.S.W., 1910, vol. 21, pp. 401-405.

29. Cockerell, T. D. A. -Notes on the Food of Birds.

New Mexico Agric. Exp. Stat., Bull. No. 37, 1901, pp. 35-51.

80. Collinge, Walter E.-On the Preservation of Wild Birds. 3rd Rpt. Inj. Insects, 1906, pp. 45-52, 9 figs.

81. Collinge, Walter E.-The Feeding Habits of the Rook, Corvus frugilegus, Linn.

Journ. Land Agents' Soc., 1910, vol. 9, pp. 183. 201 ; and Journ. Econ. Biol., 1910, vol. 5, pp. 49-67.

82. Collinge, Walter E.-Some Observations on the Food of the Starling (Sturnus vulgaris, Linn.).

Second Rpt. on Econ. Biol., 1912, pp. 63-66, 1 fig.

33. Collinge, Walter E.-The Food of the Bullfinch, Pyrrhula europaea, Vieillot.

Journ. Econ. Biol., 1912, vol. 7, pp. 49-57.

34. Collinge, Walter E.-Some Observations on the Food of Nestling Birds.

Journ. Board Agric., 1912, vol. 19, pp. 460-465.

35. Collinge, Walter E.-The Economic Status of Wild Birds.

Journ. Land Agents' Soc., 1912, vol. 11, pp. 534-538.

36. Collinge, Walter E.-The Relation of Wild Birds to Forestry. Journ. Land Agents' ISoc., 1912, vol. 12, pp. 143-146. 
36a. Collinge, Walter E.-The Destruction and Dispersal of Weed Seeds by Wild Birds.

Journ. Board Agric., 1913, vol. 20, pp. 15-26.

87. Coward, T. A.-A Note on the Little Owl, Carine noctua (Scop.), and its Food.

Mem. and Proc. Manch. Lit. and Phil. Soc., 1912, vol. $56, \mathrm{pp} .1-11$.

38. Dearborn, N.-How to Destroy English Sparrows.

U.S. Dept. Agric., Farmers' Bull. 383, 1910, pp. 1-11, 4 figs.

39. Dunlop, G. A.-The Feeding Habits of Owls.

Kilmarnock Ann. Glen Ramblers Soc., 1910, No. 6, pp. $77-79,1$ plt.

40. Estabrook, A. H.-The Present Status of the English Sparrow problem in America.

Auk, 1907, vol. 24 n.s., pp. 129-134.

41. Eifrig, C. W. G.-Stomach Contents of some Canadian Birds. Ottawa Nat., 1910, vol. 24, pp. 18-20.

42. Fisher, A. K.-The Hawks and Owls of the United States in their relation to Agriculture.

U.S. Dept. Agric., Div. Ornith., Bull. No. 3, 1893, pp. 210, plts. $1-25$.

43. Fisher, A. K.-Hawks and Owls as related to the Farmer.

Yearbook U.S. Dept. Agric., 1894, pp. 215-232, 3 plts.

44. Fisher, A. K.-Hawks and Orls from the standpoint of the Farmer.

U.S. Dept. Agric., Biol. Surv., Circ. No. 61, 1907, pp. 1-18, 6 figs. 
45. Fisher, A. K.-The Economic Value of Predaceous Birds and Mammals.

Yearbork U.S. Dept. Agric., 1908, pp. 187.194, 3 plts.

45a. Fisher, W. R.-Forest Protection.

Schlich's Manual of Forestry, vol. 4, 2nd ed., 1907.

46. Fletcher, T. B.-Swallows and Seed-dispersal.

Spolia Zeylanica, 1907, vol. 4, p. 63.

47. Florence, Laura.-The Food of Birds.

Trans. H. and A. Soc. Scotland, 1912, pp. 180-219.

48. Forbush, E. H.-Useful Birds and their Protection.

Mass. State Bd. Agric., Boston, 1905, pp. xx. +437 .

49. French, C.-A Handbook of the Destructive Insects of Victoria.

Pt. i, 1890, pp. 24-29 ; Pt. ii, 1893, pp. 181-183;

Pt. iii, 1900, pp. 139-158, 8 plts. ; Pt. iv, 1909, pp. $147-188,14$ plts. ; Pt. v, 1911, pp. 139-162, 12 plts. Melbourne.

50. French, Jr., C.-Fruit-Eating Birds.

Journ. Agric., Melbourne, 1905, pp. 1-7.

51. Frohawk, F. W.-On the Food and Feeding Habits of the Razorbill.

British Birds, 1910, vol. 4, pp. 90-92.

62. Gentry, T. G.-The House Sparrow at Home and Abroad. Philadelphia: 1878.

53. Gilbey, Walter.-Birds and Fruit Damage.

“Daily Telegraph,” 1910, Sept. 26th.

54. Gilmour, J.-Bird Investigation; an enquiry concerning the relation of certain birds to the Agricultural Interest, as shown by their diet.

Trans. H. and A. Soc. Scotland, 1896, pp. 21-112. 
55. Green, E. E.-Bird Life and its Effect on our Industries.

Tropical Agriculturist, 1912, vol. 38, no. 2, pp. 1-3.

66. Grimshaw, P. H.-The Food of the Common Pheasant.

Scottish Nat., 1912, pp. 249-251.

67. Gurney, Jun., J. H.-Are Sparrows sufficiently destructive to Agricultural Crops to be destroyed, considering the caterpillars they eat?

Reprint from “" Norfolk Chronicle," Aug. 1st, 1895, pp. 1-10, 1 fig.

58. Gurney, Jun., J. H., Russell, C., etc.-The House Sparrow. Also contains: Coues, E.-On the Present Status of Passer domesticus in America. Pp. 50-62. Miller, O. T. -A Ruffian in Feathers. Pp. 63-70.

London: 1885, pp. vii. $+70,1$ fig.

59. Gurney, J. I.-The Economy of the Cuckoo (Cuculus canorus).

Trans. Norfolk and Norwich Nat. Soc., 1898, vol. 6, pp. 365-384, 2 figs.

60. Hammond, John.-An Investigation concerning the Food of certain Birds.

Journ. Agric. Sci., 1912, vol. 4, pp. 380-409.

61. Henshaw, H. W.-Value of Swallows as Insect Destroyers.

U.S. Dept. Agric., Bur. Biol. Surv., Circ. No. 56, 1907, pp. 1-4.

62. Henshaw, H. W.-Does it Pay the Farmer to Protect Birds?

Yearbook U.S. Dept. Agric., 1907, pp. 165-178, 4 plts.

63. Henshaw, II. W.-Our Mid-Pacific Bird Reservation.

Yearbook U.S. Dept. Agric., 1911, pp. 155-164, plts. i, ii and 2 figs.

64. Herman, 0.-The Food of Birds.

Ornis., 1907, vol. 14, pp. 163-175. 
65. Herman, O., and J. A. Owen.-Birds Useful and Birds Harmful.

Manchester, 1909, pp. viii. + 388.

66. Hiesemann, M.-How to Attract and Protect Wild Birds. London: 1912, pp. 1-100.

67. Howell, A. H.-Birds that eat the Cotton Boll Weevil.

U.S. Dept. Agric., Biol. Surv., Bull. No. 25, 1906, pp. 1-22.

67a. Howell, A. H.-The Relation of Birds to the Cotton Boll Weevil.

Ibid., Bull. No. 29, 1907, pp. 1-31, 6 figs.

68. Hooper, Cecil H.-Fruit-Growing and Bird Protection.

Journ. Soc. Arts, 1906, vol. 55, pp. 72-88.

69. Hooper, Cecil H.-Birds in Relation to the Farm, the Orchard, the Garden and the Forest.

Agric. Students' Gaz., 1907. Reprint pp. 1-8.

70. Judd, S. D.-Four Common Birds of the Farm and Garden. Yearbook U.S. Dept. Agric., 1895, pp. 405-418.

71. Judd, S. D.-Methods in Economic Ornithology. Amer. Nat., 1897, vol. 31.

72.-Judd, S. D.-Birds as Weed Desiroyers.

Yearbook U.S. Dept. Agric., 1898, pp. 221-232, plt. $x v$ and 7 figs.

73. Judd, S. D.-The Food of Nestling Birds.

Yearbook U.S. Dept. Agric., 1900, pp. 411-436, plts. xlix-liii and 9 figs.

74. Judd, S. D.-The Relation of Sparrows to Agriculture.

U.S. Dept. Agric., Div. Biol. Surv., Bull. No. 15, 1901, pp. 1-98, plte. i-iv and 19 figs. 
75. Judd, S. D.-Birds of a Maryland Farm. A Local Study of Economic Ornithology.

U.S. Dept. Agric., Div. Biol. Surv., Bull. No. 17, 1902, pp. 1-116, plts. i-xvii and 41 figs.

76. Judd, S. D.-The Bobwhite and other Quails of the United States in their Economic Relations.

U.S. Dept. Agric., Bur. Biol. Surv., Bull. No. 21, 1905, pp. 1-66, plts. i, ii and 10 figs.

77. Judd, S. D.-The Grouse and Wild Turkeys of the United States, and their Economic Value.

U.S. Dept. Agric., Biol. Surv., Bull. No. 24, 1905, pp. 1-55, plts. i, ii.

78. Kelso, J. E. H.-Havoc wrought by the Starling (Sturnus vulgaris).

Zoologist, 1910, pp. 144-149, 1 fig.

79. Kerner and Oliver.-The Natural History of Plants.

Vol. 2, pp. 862-866. London: 1895.

80. Laidlaw, T. G.-Food of the Black-headed Gull (Larus ridibundus).

Ann. Scott, N.H., 1908, pp. 139-141.

81. Long, H. C.-The Value of Birds in Destroying Weed Seeds.

Common Weeds of the Farm and Garden. London: 1910, pp. 429-431.

81a. Lucas, F. A.-The Tongues of Woodpeckers. Relation of the Form of the Tongue to the Character of the Food.

U.S. Dept. Agric., Biol. Surv., Bull. No. 7, 1895, pp. $35-44$, plts. $1-3$.

82. HoAtee, W. L.-The Horned Larks and their relation to Agriculture.

U.S. Dept. Agric., Biol. Surv., Bull. No. 23, 1905, pp. 1-37, plts. i, ii and 12 figs. 
83. McAtee, W. L.-A Buried Treasure of Economic Ornithology. Science, 1906, pp. 308-312.

84. MeAtee, W. L.-Birds that eat Scale Insects.

Yearbook U.S. Dept. Agric., 1906, pp. 189-198, 3 figs.

85. McAtee, W. L.-Food Habits of the Grosbeaks.

U.S. Dept. Agric., Biol. Surv., Bull. No. 32, 1908, pp. 1-92, plts. i-iv and 40 figs.

86. McAtee, W. L.-Plants useful to attract Birds and Protect Fruit.

Yearbook U.S. Dept. Agric., 1909, pp. 185-196.

87. McAtee, W. L.-Bird Enemies of the Codling Moth.

Yearbook U.S. Dept. Agric., 1911, pp. 237-246, plts. $x$, xi.

87a. McAtee, W. L.-Woodpeckers in relation to Trees and Wood products.

U.S. Dept. Agric., Biol. Surv., Bull. No. 39, 1911, pp. 1-99, 12 plts. and 44 figs.

87b. McAtee, W. L.-Methods of Estimating the Contents of Birds' Stomachs.

Auk, 1912, vol. 29, pp. 449-464.

88. Magrath, H. A. F.-Shrikes' Larders.

Journ. Bombay N.H. Soc., 1910, vol. 20, pp. 227 228.

89. Mason, C. W., and H. Maxwell-Lefroy.-The Food of Birds in India.

Mem. Dept. Agric. India, Entom. Ser., 1912, vol. 3, pp. 1-371.

90. Myers, H. W.-Notes on Regurgitation.

Condor, Hollywood, Calif., 1910, vol. 12, pp. 165167. 
91. Nash, C. W.-The Birds of Ontario in relation to Agriculture. Rpt. Farmers. Insts. Ontario, 1897-8.

92. Newstead, Robert. - The Food of some British Birds. Suppl. Journ. Bd. Agric., 1908, vol. 15, pp. viii-87.

93. Nice, Margaret M.-Food of the Bobwhite.

Journ. Econ. Entom., 1910, vol. 3, pp. 295-313.

94. Oberholser, H. C.-The North American Eagles and their Economic Relations.

U.S. Dept. Agric., Biol. Surv., Bull. No. 27, 1906, pp. 1-31, plts. i, ii and 2 figs.

95. Ormerod, E. A., and W. B. Tegetmeier.-The House Sparrow (Passer domesticus, Linnaeus).

Pp. 1-8.

96. Palmer, T. S.-A Review of Economic Ornithology in the United States.

Yearbook U.S. Dept. Agric., 1899, pp. 259-292, plts. vi-viii.

97. Palmer, T. S.-Legislation for the Protection of Birds other than Game Birds.

U.S. Dept. Agric., Div. Biol. Surv., Bull. No. 12, rev. ed., 1902, pp. 1-143, plts. i-iv and 7 figs.

98. Pickering, C.-On the Introduction of the European House Sparrow into America, as threatening a Great Evil.

Proc. Bost. Soc. N.H., 1867, vol. 11, pp. 157, 158.

99. Pycraft, W. P.-A History of Birds.

Pp. xxxi. +458, 14 plts. and 50 figs. London: 1910.

100. Riley, C. V.-The English Sparrow in America.

U.S. Dept. Agric., Div. Ornith., Bull. No. 1. 
101. Rorig, G.-Schutz der nutzligh en Vogel Deutsche Landw. Gesel., 1904, H.98, pp. 153-176.

102. Shipley, A. E., and others.-Feeding Habits of British Birds; First Report of the Committee.

Rept. Brit. Assoc., 1909, 1910, pp. 196, 197.

108. Shrubsole, W. H.-The Protection of Useful Birds in Hungary and in Great Britain : a Contrast.

Agric. Record, 1911, pp. 12, 13.

104. Slater, H. H.-Wild Birds and the Farm.

Journ. Farmers' Club, 1905, pp. 243-260.

105. Smith, F.-The Fruit Grower and the Birds.

Maidstone, 1906, pp. 1-10.

106. Stewart, M. W.-The Food of the Black-headed Gull.

British Birds, 1908, vol. 1, p. 293.

107. Tegetmeier, W. B.-The House Sparrow (The Avian Rat) in relation to Agriculture and Gardening, with practical suggestions for lessening its numbers.

London: 1899, pp. vii. $+90,8$ figs.

108. Theobald, F. V.-Birds in the Field and Garden: Their Chief Economic Value to Man.

Live Stock Journ., 1904, Summer Number.

109. Theobald, F. V.-Economic Ornithology in relation to Agriculture, Horticulture and Forestry.

Sci. Progress, 1907, pp. 263-283.

110. Thorpe, L. D., and I. E. Hope.-Report on the Food of the Black-headed Gull.

Cumberland C. C., 1907.

111. Thorpe, L. D., and L. E. Hope.-The Food of the Blackheaded Gull.

British Birds, 1908, vol. 1, pp. 259, 260; 293, 294. 
112. Tschudi, Frederic de.-Destructive Insects and the Immense Utility of Birds.

Journ. R. Agric. Soc., 1862, vol. 23, pp. 231-246.

113. Warburton, C.-The Wild Birds' Protection Act of 1894.

Journ. R. Agric. Soc., 1895, vol. 6. pp. 365-369.

114. Wenninger, F. J.-The Economic Value of Birds.

Notre Dame, Ind., Amer. Midl. Nat., 1909, pp. 105-109.

Many useful notes and articles are to be found in the Farmers' Bulletins and Annual Reports and Yearbooks of the U.S. Department of Agriculture, the "Field," "Country Life," and the "Auk." 


\section{INDEX.}

A

\begin{tabular}{cccc} 
Accipiter nisus & \multicolumn{3}{c}{ PAG } \\
Alauda arvonsis & $\ldots$ & $\ldots$ & 66 \\
Alcedo ispida & $\ldots$ & $\ldots$ & 59 \\
A merican yellow - bellied & \\
wood-pecker, change & in \\
food habits & $\ldots$ & $\ldots$ & \\
"Avian Rat" & $\ldots$ & $\ldots$ & 3
\end{tabular}

\section{B}

Barn Owl, 61 ; post-mortem records, 62 ; examination of pellets, 62,63 ; conclusion $\ldots . \quad \ldots \quad \ldots$

Bibliography $\quad$.. $\quad$...

Bird Sanctuaries ... ...

Birds and agriculture, I ; alteration of environment, I ; and animal pests, I ; change in food habits, 2 ; as destroyers of weed seeds, $7 \mathrm{I}$; as distributers of weed seeds, 71 ; economio importance of, 9 ; establishment of orchards, 2 ; facilities for nesting, 2 ; failure of natural food supply, I; majority of species beneficial, 3 ; number of British, 4 ; number examined, 14 ; planting of fruit trees, 2 ; species examined, 14; undue increase of, Io; wholesale destruction of, unsound, 9; in relation to forestry ...

Birds of Prey ... ...

Blackbird, 19; post-mortem records, I9; field observations, 20 ; food of nestlings, 20 ; examination of faeces, 20; number trapped, 19; conclusion, 21 ; change in food habits
Blackcap, 22 ; post-mortem records, 22 ; field observations, 23; food of nestlings, 23; conclusion, 23; change in food habits ... ...

Black Grouse ... ...

Blue Tit, 25; post-mortem records, 26 ; field observations, 26 ; food of nestlings, 26 ; examination of faeces, 27,74 ; conclusion, 27 ; change in food habits Bobwhite eating weed seeds Bramling ... ... ... Brown Owl, 63 ; post-mortem records, 64 ; examination of pellets, 64 ; conclusion Rullfinch, 39 ; post-mortem records, 41 ; field observations, 42 ; food of nestlings, 42 ; conclusion ...

\section{PAGE}

\section{C}

Californian Thrasher

Calonnis chalybea

Capercaillie

Capringulus europaeus

Carduelis elegans

Carpodacus mexicanus frontalis ... ... ...

Chaffinch, 36 ; post-mortem records, 36 ; field observations, 37 ; tood of nestlings, 37 ; conclusion ...

$\begin{array}{cc}\ldots & 79 \\ \ldots . & 78 \\ \ldots . & 81 \\ \ldots . & 84 \\ \ldots . & 30 \\ \ldots & \\ \ldots & \text { I0 }\end{array}$

Chamaea fasciata ..

Chipping Sparrow ... $\quad$... $\quad 12$

Chrysomitris spinus $\quad \ldots \quad 8 \mathrm{I}$

Coccothraustes vulgaris $\quad \ldots . \quad 8 \mathrm{r}$

$\begin{array}{llll}\text { Columba oenas } \quad . . & \ldots & 68\end{array}$

Columba palumbus... $\quad \ldots .66$

$\begin{array}{llll}\text { Columbidae } & \ldots & \ldots & \text { II }\end{array}$

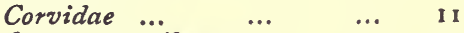

Corvus frugilegus ... $\quad \ldots \quad 55$

Corvus monedula ... $\quad \ldots \quad 53$ 


$\begin{array}{lrrr} & & & \\ \text { Crossbill ... } & \ldots & \ldots & 81 \\ \text { Crows, Judd's observations on } & 79 \\ \text { Cuckoo } \ldots & \ldots & \ldots & \text { II } \\ \text { Cuculus canorus } & \ldots & \ldots & \text { II }\end{array}$

D

Dark-blue Starling...

Darwin's observations on the dispersion of seeds $\quad \ldots \quad 78$

Dendrocopus major... $\quad . . \quad 8 \mathrm{I}$

Dendrocopus minor $\quad$... 8I

Dipper .. $\quad \ldots \quad$... 11

Drinking water, provision of 9 !

E

Economic Ornithology _.. I

Emberiza citrinella $\quad \ldots \quad 42$

Experimental Station at See-

bach ... ... ...

\section{F}

Faeces, Examination of $8,73,75$

Falco tinnunculus ... $\quad . .6 \quad 65$

Fieldfare, 18 ; post-mortem records $\quad . . . \quad$...

Field Vole, 84 ; damage done, 84 ; fecundity of $\quad .$.

Flycatchers

Food of Birds, 1 ; change in food habits, 2 ; failure of natural food ... ..

Food of Nestlings, Observations on

Forests, Birds in relation to

Frigate - birds distributing seeds ... .. $\quad$...

Fringilla coelebs ... $\quad . .78$

Fringilla montifringilla $\quad \ldots \quad 8$...

G

Game-birds $\begin{array}{lll}\text {... } & \text {... II }\end{array}$

Garrulus glandarius $\quad$... 50

Gecinus viridis $\quad . . \quad \ldots \quad \ldots \quad 8 \mathrm{I}$

Goldfinch, 30 ; post-mortem records, 30 ; field observations, 31 ; conclusion

Great Spotted Woodpecker

Great Tit, 23 ; post-mortem records, 24 ; field observations, 24 ; food of nest. lings, 24 ; conclusion ...

Greenfinch, 28 ; post-mortem records, 29 ; field observations, 29 ; food of nest- lings, 29 ; examination of faeces, 29,75 ; conclusion Green Woodpecker .. 8 r Gulls $\quad \ldots \quad \ldots \quad \ldots$ II

\section{H}

$\begin{array}{llll}\text { Hawfinch .. } & \text {.. } & \ldots & 8 \mathrm{r}\end{array}$

$\begin{array}{lllr}\text { Historical Review ... } & \ldots & 5 \\ \text { Hornbills ... } & \ldots & \ldots & 78\end{array}$

House Finch, ro ; animal food eaten, 10 ; fruit, 10 ; stomachs examined, 10 ; weed seed ... ...

House Sparrow, 31 ; postmortem records, 32 ; field observations, 34 ; food of nestlings, 35; examination of faeces, 35,73 ; conclusion, 35 ; relation to agriculture

$$
\text { ... } \quad \ldots
$$

$\begin{array}{llll}\text { House Wren } & \ldots & \ldots & 12\end{array}$

\section{I}

Injury to insectivorous birds Injury to trees $\quad \ldots \quad \ldots, 3,8$ $\begin{array}{llll}\text { Introduction } & \ldots & \ldots & \text { I }\end{array}$ Iynx torquilla $\quad \ldots \quad$... $\quad$ I $\mathrm{J}$

Jackdaw, 53 ; post-mortem records, 54 ; field observations, 54 ; conclusion ... Jay, 50 ; post - mortem records, $5^{\circ}$; field observations, $5^{1}$; conclusion ... Judd's observations on crows Judd's observations on the dispersion of seeds $\quad \ldots \quad \quad 7^{2}$

\section{K}

Kerner's experiments on the dispersion of seeds ...

Kestrel, 65 ; post-mortem records, $6_{5}$; examination of pellets, 66 ; field observa. tions, 66 ; conclusion ... King fisher

L 
Lesser Spotted Woodpecker

Ligurinus chloris ... ...

Linnet, 38 ; post-mortem records, 38 ; field observations, 39 ; food of nestlings, 39 ; conclusion ..

Linota cannabina ... $\quad . . . \quad 38$

List of birds examined $\quad$... $\quad$ I4

List of birds injurious to forests $S_{\text {I }}$

Long-eared Owl $\quad \ldots \quad \quad \ldots \quad 84$

Long - tailed field mouse, damage done by $\quad \ldots \quad 84$

Loxia curvirostra ... $\quad \ldots \quad 8$ I

\section{M}

Magpie, $5^{1}$; post-mortem records, 52 ; field observations, 52 ; conclusion ...

Mainatus savatus ... ..

Martins ... ... ...

Mason's observations on seedeating birds

Melanerpes erythrocephala ...

Methods of examination ...

Minah

Missel Thrush, I5 ; post-mortem records, I6 ; field observations, I6; conclusion

\section{$\mathbf{N}$}

Nesting Boxes, provision of

Nestlings, 12 ; food of, 12 ; number examined $\quad \ldots \quad$ I5

$\begin{array}{lllll}\text { Nightjar } & . . & \ldots & \ldots & 84\end{array}$

Nucitraga caryocatactes ... $8 \mathrm{I}$

$\begin{array}{llll}\text { Nutcracker } & \ldots & \ldots & 81\end{array}$

$\begin{array}{lllll}\text { Nuthatch } & \ldots & \ldots & \ldots & \text { I I }\end{array}$

Nuttall's sparrow eating weed seeds ... ...

O

Observations in the Field

Observations on the food of

\begin{tabular}{ccccr}
\multicolumn{2}{r}{ nestlings } & $\ldots$ & $\ldots$ & 8 \\
Owls & $\ldots$ & $\ldots$ & $\mathbf{i}, 83,84$
\end{tabular}

\section{$\mathbf{P}$}

$\begin{array}{lccr}\text { Parus caeruleus } & \ldots & \ldots & 25 \\ \text { Parus major } & \ldots & \ldots & 23 \\ \text { Passer domesticus } & \ldots & \ldots & 3 \mathrm{I} \\ \text { Passerina nivalis } & \ldots & \ldots & 7 \mathrm{I} \\ \text { Pellets, Examination of, } & 8,62,63,64 \\ \text { Phasianus cocchicus } & . . & 8 \mathrm{I}\end{array}$

5

84

84




\begin{tabular}{|c|c|c|c|c|c|}
\hline & & & GE & & AGE \\
\hline Sturnus vulgaris & ... & .. & 44 & W & \\
\hline Swallows ... & ... & .. & II & Wagtails ... & I I \\
\hline Sylvia atricapilla & ... & ... & 22 & Warblers ... & I I \\
\hline Sylvia cinerea & $\cdots$ & $\cdots$ & 21 & Weed seeds destroyed by birds & 71 \\
\hline Syrnium aluco & ... & ... & 63 & $\begin{array}{l}\text { Weed seeds distributed by } \\
\text { birds ... } \\
\text { Whitethroat, } 2 \text { I ; post-mortem } \\
\text { records, } 2 \text { I ; field obser- }\end{array}$ & 72 \\
\hline Tachypetes aquila & ... & ... & $7^{8}$ & & 22 \\
\hline Tawny Owl & .. & $\ldots$ & 83 & $\begin{array}{l}\text { Wild Birds Protection Acts } \ldots \\
\text { Woodpeckers, } 82 \text { economic }\end{array}$ & \\
\hline Tetrao tetrix & $\cdots$ & .. & $8 \mathrm{I}$ & status, 82 ; in relation to & \\
\hline $\begin{array}{l}\text { Tetrao urogullus } \\
\text { Toxostoma rediviva }\end{array}$ & $\cdots$ & $\cdots$ & $8 I$ & forests & 82 \\
\hline $\begin{array}{l}\text { Toxostoma rediviva } \\
\text { Tree Creepers }\end{array}$ & a. & $\cdots$ & $\begin{array}{l}79 \\
\text { I I }\end{array}$ & Wood Pigeon, 66 ; post-mor- & \\
\hline Troglodytes aëdon & $\cdots$ & $\cdots$ & 12 & tem records, 67 ; examina- & \\
\hline Troglodytes parvult & & $\cdots$ & 27 & clusion $\quad \ldots$, & 68 \\
\hline Turdidae ... & $\cdots$ & $\cdots$ & $1 \mathrm{I}$ & Wren, 27 ; field observations, & \\
\hline $\begin{array}{l}\text { Turdus merula } \\
\text { Turdus musicus }\end{array}$ & $\cdots$ & $\cdots$ & $\begin{array}{l}19 \\
16\end{array}$ & 27 ; food of nestlings, 28 ; & \\
\hline Turdus pilaris & $\ldots$ & $\ldots$ & 18 & conclusion & 28 \\
\hline Turdus viscivorus & $\ldots$ & $\ldots$ & I5 & Wren Tit ... & 79 \\
\hline Turtle Dove & .. & $\ldots$ & $8 \mathrm{I}$ & Wryneck $\ldots$ & I I \\
\hline Turtur communis & . & $\ldots$ & 81 & & \\
\hline & & & & $\mathbf{Y}$ & \\
\hline V & & & & $\begin{array}{l}\text { Yellow Bunting, } 42 \text {; post- } \\
\text { mortem records, } 43 \text {; field }\end{array}$ & \\
\hline $\begin{array}{l}\text { Vanellus vvlgaris.. } \\
\text { Voles }\end{array}$ & & $\cdots$ & 69 & observations, 44 ; food of & \\
\hline voles $\cdots$ & ... & $\cdots$ & 04 & s, 44 & 44 \\
\hline
\end{tabular}




\section{PROTE(T \\ CORNFIEL

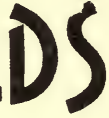

Barley, Wheat, Peas, Oats, Beans, Maize, Cares, FROM

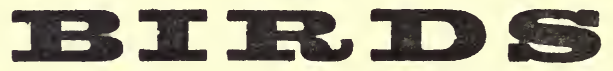

PREMATURE GROUND ROT AND SMUT BY USING
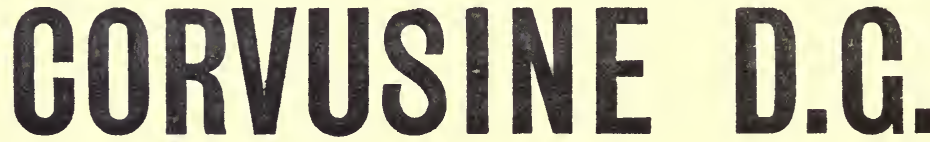

The Wonderful non-poisonous Beed Dressing.

\section{NO TROUBLE FROM}

ROOKS, WOODPIGEONS, PHEASANTS, AND OTHER BIRDS.

CAREFUL MEN READ THIS.

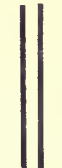

Thousands of Farmers, including the Royal Farms, and the Principal Estates in the Country, annually use and recognise the incomparable value of Corvusine. Ask for and be sure you get CORVUSINE D.G., the original Liquid Seed Dressing, which is prepared by an exclusive process to produce the highest percentage of germination and wall not injure the seed. Refuse worthless imitations if you value your crops.

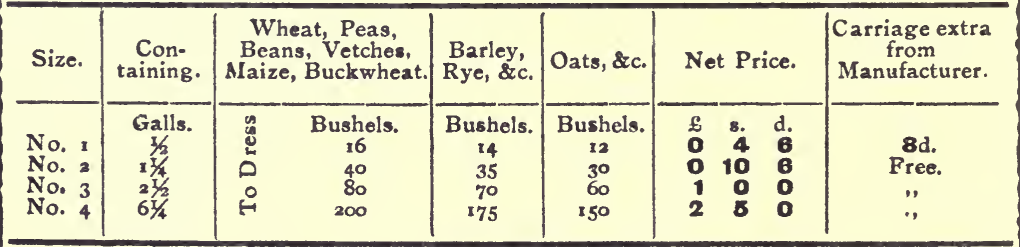

Stocked by Corn-Seedsmen, Chemists and Ironmongers everywhere, or in case of difficulty write direct to the Sole Manufacturer

Manufactured only by

ARTHUR E. HAWKER, 59 Mark Lane, LONDON, E.C. 
"Very interesting and suggestive,"-Garden Life.

- Well written and illustrated, and gives directions. suggestions and hints from practical growers for the safeguarding of agricultural crops, fruit and vegetables."-Mark Lane Express.

\section{Farm, Garden, \& Birds:}

How to Protect Corn, Fruit and Vegetable Crops without destruction of Bird-life.

Prize Essay by E, Purnell Jones and E. J. Platt. and Extracts from 26 others. The Judges were: Mr. G. L. Courthope, M.P.. Mr. C. F. Archibald, and Dr. F, P. Haviland.

ONE SHILLING, post free, from the ROYAL SOCIETY FOR THE PROTECTION OF BIRDS, 23, Queen Anne's Gate, S.W.

Encourage useful Insectivorous Birds by putting up

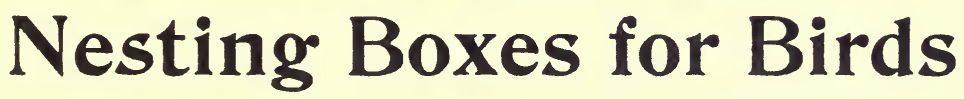

Illustrated Catalogue of British and Berlepech Patterns sent free by the ROYAL SOCIETY FOR THE PROTECTION OF BIRDS, 23. Queen Anne's Gate, S.W.

Boxes for Owls, Flycatchers, Wrynecks, Nuthatches, Woodpeckers, Tits. Wagtails and others.

READ THE SOCIETY'S QUARTERLY-

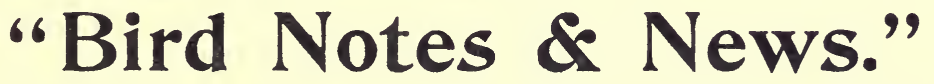

ONE SHILLING per annum; Single Number. THREEPENCE.

\section{Cbe Royal Socieiy for the Protection of Birds,}

23, QUEEN ANNE'S GATE, LONDON, S.W. 


\section{Geo Roobottom \& Sons, Limited,}

Printers.

Aston, Birmingham. 


S.ST

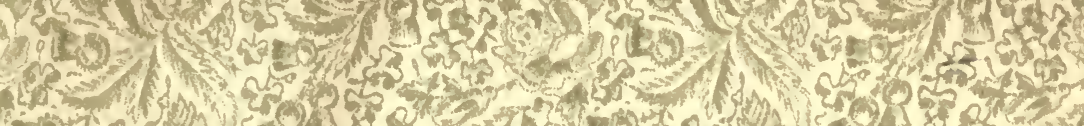

$3<-9$

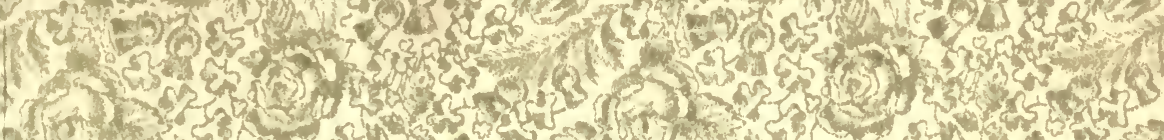

(1) 4. ज.

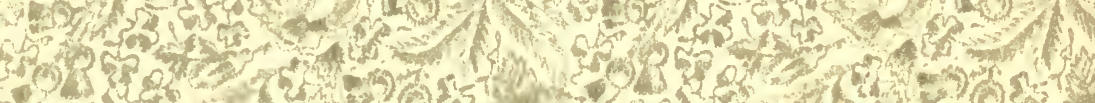
a 4 -

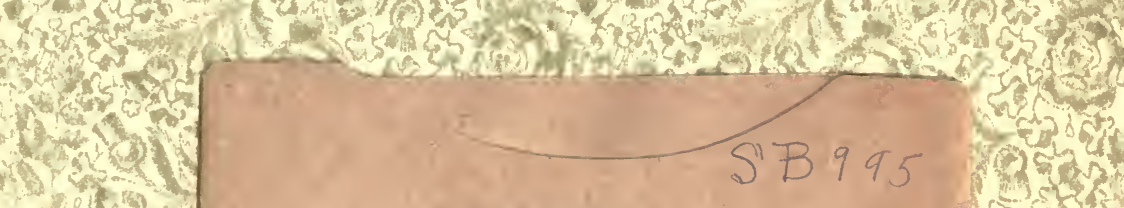

$$
\begin{aligned}
& -\infty
\end{aligned}
$$

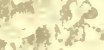

$$
\begin{aligned}
& \text { (1) } \\
& \cos 20 \\
& 274254 \\
& \text { @ollinge, } 6.6 \text {. } \\
& \text { YC } 6 \text { igng }
\end{aligned}
$$
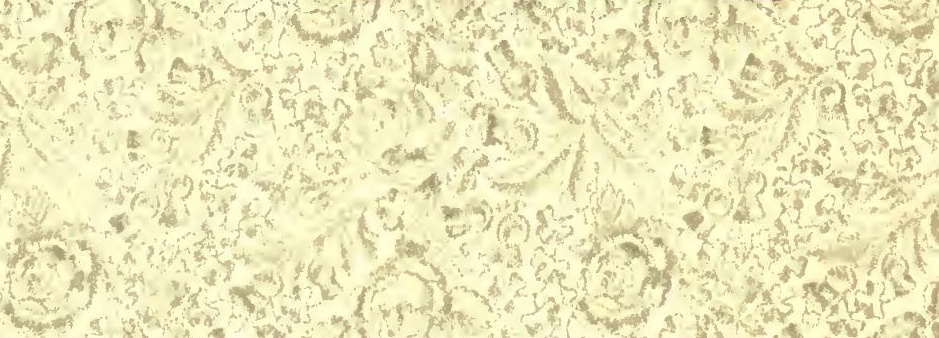
(3). 
